

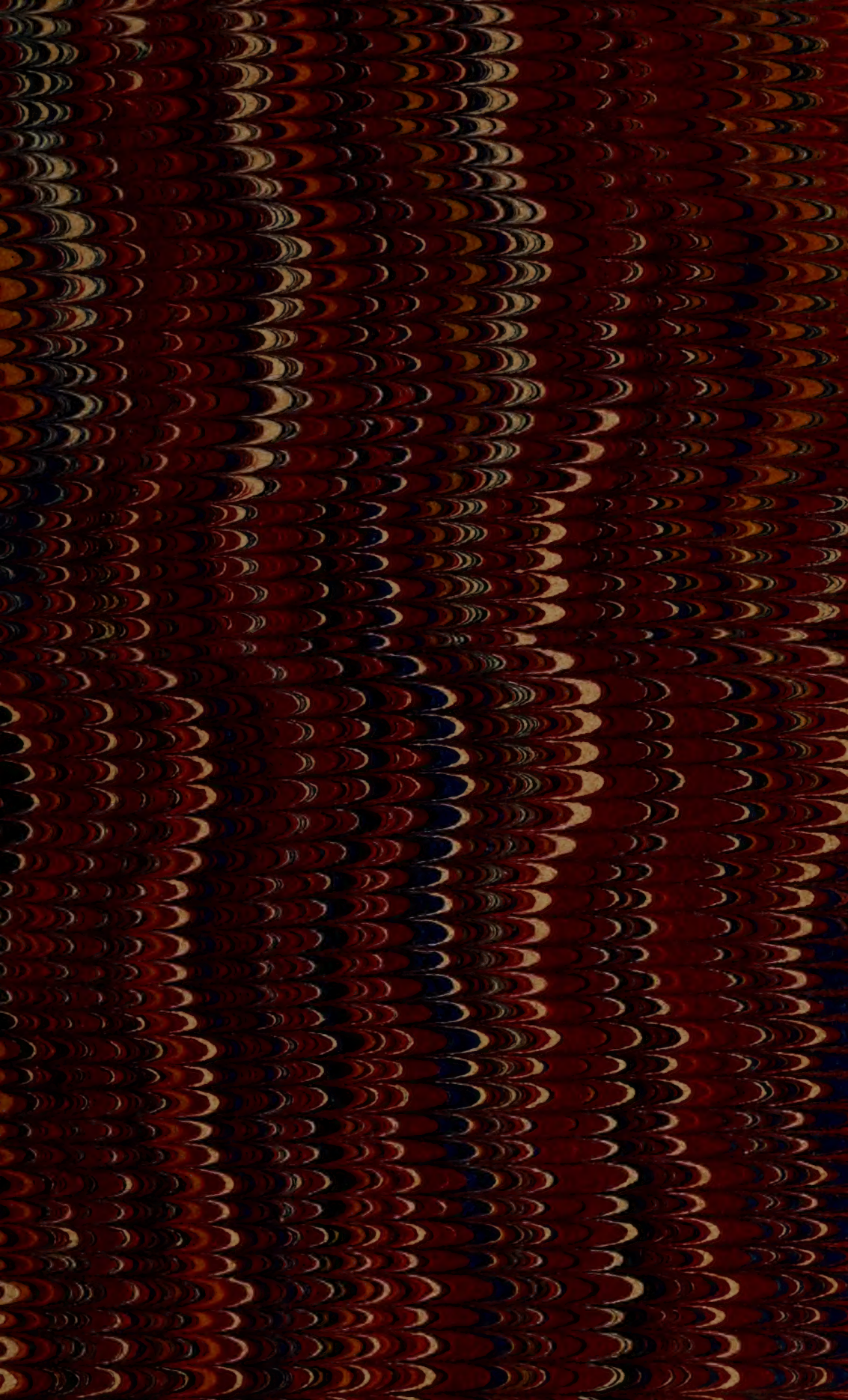










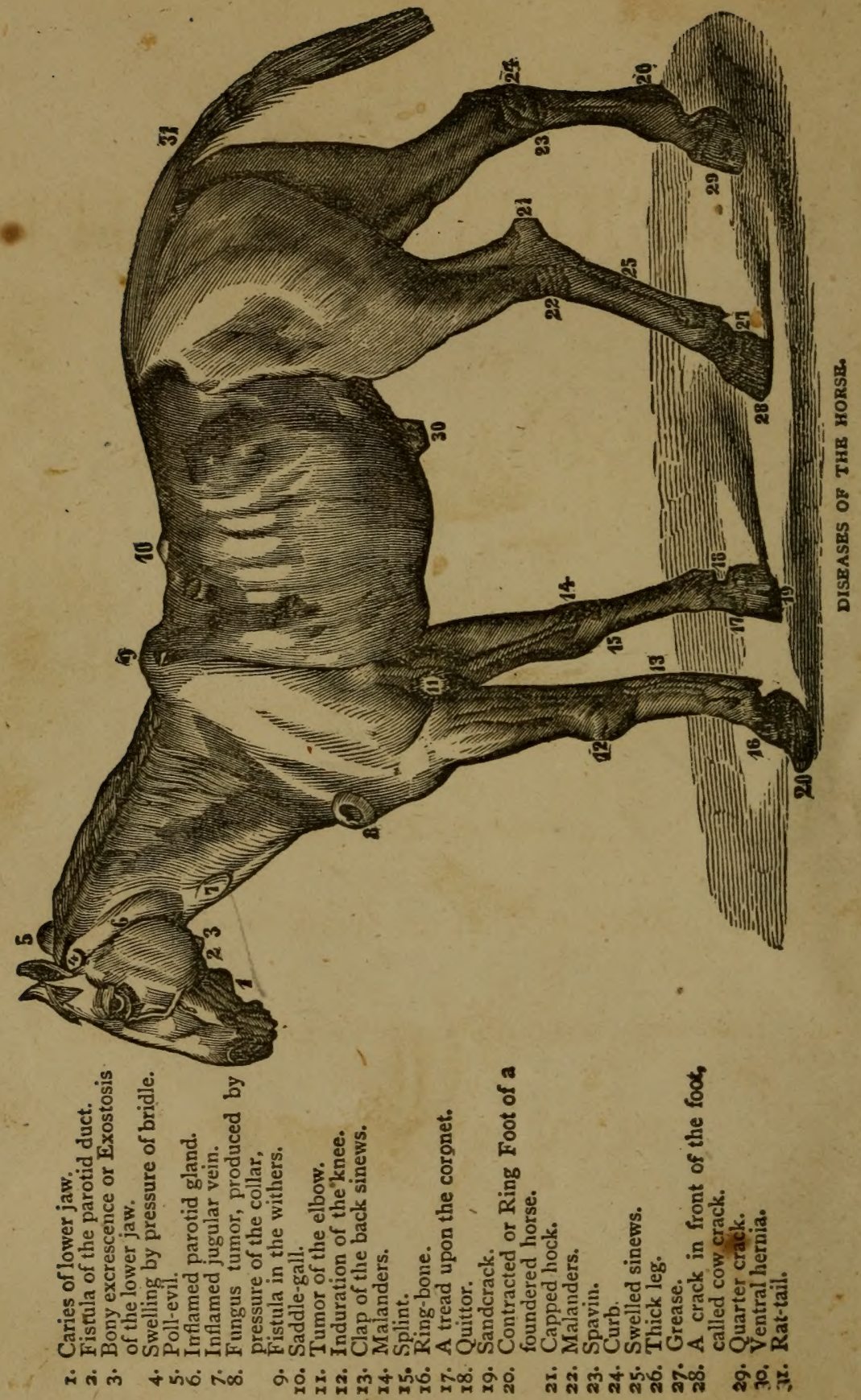




\section{DE WITT'S COMPLETE}

\section{AMERICAN FARRIER}

\section{AND \\ HORSE DOCTOR. \\ AN}

\section{AMERICAN BOOK FOR AMERICAN HORSEMEN,}

WITH COPIOUS NOTES FROM THE BEST ENGLISH AND AMERICAN AUTHORITIES.

8HOWING PLAINLY HOW TO

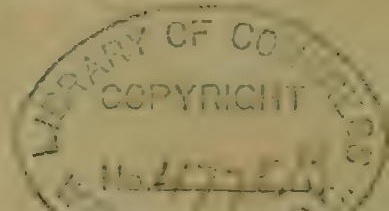

BREED, REAR, BUY, SELL, CURE, SHOE AND KEEP

THAT MOST USEFOL AND VALUABLE ANIMAL, THE HORSE.

\section{BY COL. CHRIS. FORREST,}

NEW YoR R:

ROBERT M. DE WITT, PUBLISHER,

No. 33 Ros: STREet,

Between Durne and Frarkfort Streets. 


\section{THE COMPLETE AMERICAN FARRIER}

AND HORSE DOCTOR.

Entered according to Act of Congress, in the year 1870, by

ROBERT M. 'DE WITT,

In the Office of the Librarian of Congress, Washington, D. C. 


\section{CONTENTS.}

\section{CHAPTER FIRST.}

THE HORSE IN AMERICA.

Hislory of the American horse-Breeds-Origin-Effects of climate and food-Importation-Pony breeds.............................

CHAPTER SECOND.

\section{HOW TO BUX A HORSE.}

What do sou want him for?- What is his work to be, and what sort of horse does your work call for?-What sort of country do you live in? -What are your facilities for stabling and feeding ?- What do you know about a horse ?-What is your market ?.... .................

CHAPTER THIRD.

IOOKING $\mathrm{AT}$ T IIORSE.

External peculiarities-Color of coat and feet-Condition of the coatTaking him out of the stable-The age of the horse-The marls in his teeth-The head and neck-The ear-The eyes-The nostrils......

CHAPTER FOURTH.

MORE ABOUT BUYING A HORSE.

The horse's neck-Poll-evil-The shoulder and its marks-The chestThe foreleg and knee-Knee-sprung and splints-Tied in below the

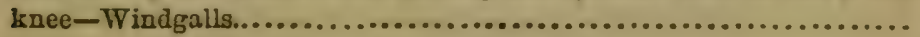

\section{CHAPTER FIFTH.}

\section{EXTERNAL SIGNS OF DISEASE.}

The body of the horse-Form of back and barrel-Flesh and the want of it-Fistulous withers and other sores-The loins and haunches-The hock and its diseases-Windgall, Curb, Capped-hock, Spavin, Stringhalt, Mallinders, \&rc. -Feet and ankles...................... 


\section{CHAPTER SIXTH.}

1

\section{TRYING YOUR PURCHASE.}

Taking a guaranty-Get a chance to try the horse-Lead him home yourself-Signs of stumbling-The feed test-Promptness in taking

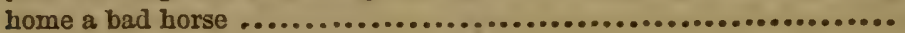

CHAPTER SEVENTH.

\section{SOME GENERAI A D VICE.}

Disposition, temper, courage-Deceptive appearances-English colt racing-Hard usage of young horses-Decrease of value-Increase of value-Problems for horse-owners...............................

\section{CHAPTER EIGHTH.}

STABIESANDEOOD.

Bad stabling in America-Stabling in the South and West-Sudden exposure-City stabling-Stalls and boxes-What room a horse wantsFresh air and ventilation-Stable floors and drainage-Light and warroth-Dampness and its evils-Location and temperature-Bedding and feeding...............................................

\section{CHAPTER NINTH. \\ STABLING AND GROOMING.}

Grooming and cleanliness-Perspiration and scurf-Rubbing and brushing-Mud, wet legs and washing-Hoofs and heels-Cooling downShedding the coat-The fetlocks-The hoof in the stable-Preparation for shoeing-Wet floors and "Thrush "-Examining the shoes-Exercise....................................................

\section{CHAPTER TENTH.}

\section{PASTURE. HINTS.}

Soundness of hay or grain-Green food and soiling-Changes of food$\mathrm{Bad}$ weather and extra care-Shelter in the pasture lot-Watering in pasture-Flies in the field-Taking up from pasture.................

\section{CHAPTER ELEVENTH.}

\section{THE HORSE'S FOOT.}

Careless shoeing-Feet of wild horses--Shoeing in ancient time-Army "arriery-Necessities for protection-Uses of the shoe-Methods of acquiring information-Parts of the hoof and their uses-Waste and injury-Machine-made shoes..................................

\section{CHAPTER TWELFTH.}

\section{HINTS ON HÁRESS.}

IIarness for work-Bad harnessing a waste of power-Friction and sores-Woodruff on pulling-Tricks in work-Relief from harness in rest.................................................... 


\section{CHAPTER THIRTEENTH.}

STABLE TRICKS AND VICES.

Stall kicking-Weaving-Tearing the clothes off--Vicious to clean-Crib bitting-Y $-Y$ indsucking-Refusing to lie down-Pawing-QuiddingRolling-Biting........................................

\section{CHAPTER FOURTEENTH. \\ OUT OF DOOR TRICKS AND VICES.}

Shying in harness-Rearing-Kicking in harness-IRunuing away-Lying down in harness-Hard pulling-Overreach-Cutting-Stumbling-

Balking.................................................

\section{CHAPTER FIFTEENTH.}

\section{DISEASES OF HORSES.}

Bone diseass-Classification-Splints-Ringbone-Spavin-Fistula of the withers _Poll-evil-Ulcer of the jaw-Bighead-Fracture........... 10j

\section{CHAPTER פIXTEENTH.}

DISEASES OF HORSES.

The joints, muscles and tendons-Rheumatic inflammation-Bog-spavin Thoroughpin-Windgalls-Capped-hock-Strain of back sinewsStrain of shoulder, knee, fetlock and coftin-bone-Breaking downStrains of hip-joint, stitle and hock-Curb-Dislocation-Wounds of joints.

\section{CHAPTER SEVENTEENTH.}

\section{DISEASES OF TUE HORSE.}

Internai diseases-Catarrh-Distemper-Bronchitis-Chronic coughFoaring and whistling-Pneumonia-Congestion-Pleurisy Broken wind-Phthisis-Bleeding at the nose.

\section{CHAPTER EIGHTEENTH.}

\section{DISEASES OF THE HORSE.}

The abdomen and its appendages-Sore throat-Strangles-LampasGastritis-Dyspepsiu-Bots and their history.

\section{CHAPTER NINETEENTH.}

\section{DISEASES OF MORSES.}

Inflammation of the bowels-Colic-Diarrhoea and dysentery-Strangulation and hernia-Womas-Liver disease-Kidneys-DiabetesBladder, etc.............................................. 161 


\section{CHAPTER TWENTIETH.'}

MISCEI I A EO US DISEASES.

Convulsions - Mad staggers - Madness - Megrims-String-halt - Sunstroke-Stomach staggers-Lockjaw-A poplexy ...................

CHAPTER TWENTY-FIRST.

Diseases of the ear-Diseases of the eye-Cataract-Buckeye-Simple inflammation-Epidemic ophthalmia-Specific ephthalmia-SurfeitMange-Mallinders-Scratches-Founders-Navicular disease-Overreach...

CHAPTER TWENTY-SECOND.

$$
\text { FEVER-TXPHOID FEVER. }
$$

Fever-Typhoid fever-Glanders-Farcy.

CHAPTER TWENTY-THIRD.

\section{BREEDING.}

Influence of sire and dam-Heat-Inheritance of qualities-Age-SizcFoaling-Working mares-Weaning-Feeding-Handling.......... 198 CHAPTER TIFENTY-FOURTH.

TRAINING FOR WORR. 


\section{PREFACE.}

Mx dear reader, a man who does not honestly love a good horse does not deserve to own one, and certainly is not fit to write advice to others concerning the management of that noble animal. Mere fondness for horses, however, may co-exist with the most senseless prejudices and the darkest ignorance, and many a poor brute who has suffered torture from the hands of his human neighbors has had occasion to whinny forth, "Deliver me from my friends!"

In these latter days, to be sure, when all the world seems yearly to be growing more sensible and merciful, the Rarey system, or rather its professed principle, the example and instruction of such true friends of the horse as Frank Forrester and Hiram Woodruff, and many kindred agencies, hare been at work to ameliorate the condition of "man's best and noblest four-foot friend," but a great deal remains to be done. The doctrines and teachings of our great American horsemen, second to none in the world, require to be condeused and popularized for general use, and it is to this task, in part, that I have set myself, with a genuine love of my subject, intending to write for American readers only. My hope is that the many scores of thousands who have been my willing followers in fields of fiction will go with me none the less readily now that I am dealing with useful facts and practical realities.

Experts and professional horsemen who mas chance to refer to these pages will not be long in finding that I have not attempted to write for them, and may even differ with no on somo points, 
though I have little fear that any two will find the same fault, so notional and self-opinionated are men on the subject of the horse. Genuine experts, and those who are really fit to be called "professionals," have no need of a popular treatise like this, but they are very few in number, while I have written for that vast multitude. who have little or no exact information of this kind, and whose inquiring minds would only be confused and bewildered by technical terms and elaborate disquisitions. For this multitude the information furnished must needs be condensed and superficial, but should be such as will put them on the right track, so that all their future experience may build upon a good foundation of common sense, unhampered by crude notions and antiquated prejudices. The world has outgrown a good deal that was counted for wisdom a few generations ago, and some of the old "horse books" are but stupid collections of "old grannyisms," or directions for the commission of cruel barbarities in the way of cuttings, burnings, cauterizations, physicking, nicking, etc., which the veriest groom in the stables of Bonner or' Vanderbilt would turn pale to think of putting in practice on anything worthy to be called a HoRse.

If I accomplish my real purpose faithfully and successfully I shall have done quite enough to make this trearise widely valuable. 


\section{THE}

\section{COMPLETE AMERICAN FARRIER AND HORSE DOCTOR.}

CHAPTER FIRST.

THE HORSE IN AMERICA.

Iistory of the American horse-Breeds-Origin-Effects of climate and food -Importation-Pony breeds.

That the horse was intended for the companion and servant of the human race is evidenced by the fact that, next to man himself, he exhibits, of all created animals, the greatest adaptability to extreme changes of climate, usage, food and other circumstances. With a rapidity which is little less than marvellous, he developes those special peculiarities of breed, involving changes of size, bone, muscle and habit of life, which prepare him to meet the immediate necessities as well as resources of those who are to employ him. On the steppes of Tartary the horse seems to have been expressly designed for the vicissitudes of the hardy nomad wanderers whose mode of life requires from him little else besides speed and endurarice: among the arid deserts of Arabia he developes a light and almost fleshless contour, capable of sustaining an extreme amount of exertion upon a handful of barley and a few dates: in the low countries of Europe, where for ages he has never been called upon for speed, he becomes the gigantic, bony, muscular, powerful Flemish draught horse, once in as great demand for carrying hearily armored knights into battle as he now is to pull the mountainous loads of barrelled beer and other merchandise; while among tho North British Isles he dwindles to a pony whose dwarfish proportions are as well supported on half-decayed fish as are his contiuental brethren on grass and grain. 
It would seem that the history of the world had tested sufficiently the wonderful adaptability of the horse, but it remained for the New World to complete and verify the record of his powers.

When Columbus discovered America, there was not one solitary specimen of the equine race on all the rast expanse of continent and island, from Labrador to Terra del Fuego, and the fierce warriors who afterwards opposed the advance of Cortes and his men imagined the Spanish cavalry to be recruited from some miraculous race of centaurs:-horse and man were to them but one fearful being, designed by the avenging gods for the destruction of offending Mexicans.

The different breeds of horses had therefore a new field wherein to test themselves, and from that day to this their history has been one of continuous experiment.

We may note that from first to last only serviceable animals have been brought over from the Old World, and for the most part only such as were specially selected, either for military or domestic use, or for direct stock purposes.

No reliable record has been kept of the earlier importations, but we are aware, generally, of their special characteristics, and may even trace in their descéndants some evidences of original peculiarities. The Spaniards, at the south of North America and in South America, introduced Andalusian barbs and other stock, of Moorish and Arab blood, while the French, the Dutch and the English, who colonized the more northerly regions, brought over with them the several breeds which in a manner represented their own nationalities. It would be a matter more of curiosity than service to incuire more minutely into the parentage and quality of these equine patriarchs, but we are able at the present day to noto with what ready facility all original characteristics liave yielded to the influences of climate, food and usage. Among our north-east. ern islands the "shelties" of the British Isles have been almost precisely reproduced : Canada has brought out a distinct and peculiar breed of undersized ponies: New England, at an early day, gave us the Narragansett pacers, unlike anything else, and now nearly extinct, and, still later, the useful "Morgans:" our Western Indians have bred a race of ponies which have not cren yet presented sure tokens of a distinct type, while far to the south the Spanish stock has developed the unmistakable and, except 
for certain uses, very undesirable mustangs. On the Pacific slopo still another breed is rapidly coming to perfection, differing in many respects from all the others, but time has not yet sufficed to dotermine a distinct type: speed and endurance, with a diminution of weight and bone, seem to indicate a Western development of a more than Arabic type of "travellers." A curious oddity of pony life has been bred among the endless marshes of the Atlantic coast of the Carolinas, in the shape of a race of little quadrupeds, for the most part tolerably well formed, easily tamed and tractable, but whose peculiar constitutions forbid their transfer to other climates. The writer of this was present, a few years since, when a large drove was brought in, fresh from the marshes, and purchased a very pretty and well formed stallion. His size, under twelve hands, was all that marked him as a "pony," as there was nothing of the heary headed "sheltie" about him. Timothy and clover he rejected, and grain he did not understand: he endured a good deal of thirst before he would touch fresh water, but salt enough to make it a trifle brackish at once reminded him of his native "tide water" streams, and he took to it very kindly. An attempt to transfer him and some of his wild companions to a Northern State utterly failed, for, in the absence of his coarse swamp grass and canebrake, he pined away and died.

Year by year our American breeders have persistently, if sometimes m:stakenly, invested their care and cash in the importation of fresin blood from the various European breeds, and it is a question in the minds of our best horsemen if this process has not been carried quite fur enough, whether, in fact, any additional transatlantic crosses serve any other purpose than to impecle the natural derelopment of the true American type of horse. Our North may borrow with advantage from our South, and vice versa, but it is by no means certain that Arabia herself has not anything desirable to lend us. Assuredly we have no occasion to send abroad for any mate or match to that unrivalled animal for all purposes of work or pleasure, the American Trotter, to whose development so many of our soundest horseman have devoted their capital and their intelligence. And yet in a country so vast as our own, including within its limits so many degrees of latitude and such endless varieties 'of climate, population and production, it is impossible that any one peculiar breed should prove universal in its adaptation, or that the 
same horse should be found equally valuable in all the nultiplied vicissitudes of American life, and the recommendations and suggestions ventured in the present work will be made always with reference to the plain dictates of common sense, as based upon this fundamental fact. The beast whose special fitness renders him invaluable among the pared streets of an Eastern city would leave his carcass a dinner for the "Mexican eagles," by the roadside, long before his more enduring Western cousin had discovered, that ho was on a "long trail," or that foclder and stabling were unsatisfactory. Nevertheless, the son or grandson of that same Eastern stallion if born on the prairies, would be found, in erery case, to have developed all the local peculiarities called for, besides carrying with him something from his birthright to convince his breeder that "crosses are desirable." Intelligent breeding in our climate should in due time make a "pony" of any kind an impossibility, but, in default of that, whole races, both of horses and of men, dwindle into ponies, the redeeming fact being that nobody is especially interested in their preservation, and that they are gradually " eliminated." 


\section{CHAPTER SECOND.}

\section{IIOW TO BUY A HORSE.}

What do you want him for? - What is his work to he and what sort of horse does your work call for ?-What sort of country do you live in ?--What are your facilities for stabling and feeding? - What do you know about a horse? -What is your market ?

OxE singular twist of human nature shows itself in the fact that no man has yet been found of such honesty or humility that he was not ready to advise his neighbor about buying a horse. Fellows who nerer held a rein or climbed into a saddle, are ready to cock their heads knowingly and shed a perfect flood of darkness and ignorance over the qualifications of any quadruped whatsoever that may be offered for sale. Our own notion is that, as a general thing, a man is his own best counsellor in such a case, if he will be guided by a little thoughtful common sense, and that if he doubts his own ability he had better either trust to blind luck or apply to a professional horseman. The latter course ought to cost him an honest fee, but would probably prove the best policy in the end. At ail "rents, purely volunteer advice may well be discarded, especialiy if it cones from a "disinterested stranger."

As not every man, however, seems to be endowed with common sense, or the capacity to employ it in the horse business, we renture a fow suggestions by way of aiding in calling that valuable faculty into action.

In the first place, then, if you want to buy a horse, what do you want him for?

What is the nature of the work to which you propose to put him? Do you want a roadster for steady and regular pulling, wilh a moderate load, and with very little occasion for speed?

Is it a horse for quick and light work, and now and then a demand for a rapid "burst?"

Do you want a plough horse, a fellow to stand up to his collar with a ton of hay or a load of stone behind him, a tower of strength and a mountain of bone? 
Is your horse to work all day moderatel $\dot{5}$, or a part of a diny severely?

Is your case exceptional, and are you after a show horse, or that expensive luxury, a fast horse?

In short, what do you want? Make up your mind about that, the first thing, and also assure yourself that you will find no one beast that will be equally well adapted to all emergencies.

Flora Temple would hardly have distinguished herself before a dray, nor would Bonner be apt to appear on Harlem Lane behind the seventeen-hand beauties who do the pulling for the fire-proof safe men. The horse for his work and the work for the horse, and the man of sense will apportion the one to the other. Extremes should in most cases be avoided. Few men require a very heavy horse. Ordinary American farm work cannot profitably employ an elephant. A thin or weedy beast is used up too soon, though many such inprove remarkably in wor's, and the better plan is to select a well-barrelled, strong-limbed animal, rather under sixteen hands high, and capable of being employed to advantage in a great variety of uses. That is the economical and business-like idea, but its application by yourself pre-supposes that you are not an idiot-in fact we would not undertake to advise a fool for any money.

And now if you have carefully consulted your business and requirements, and have fully made up your mind as to the special needs which lead you to such an affair as the purchase of a horse, suppose you look a little further and inquire as to the nature of the country in which you are to use your quadruped servant after you have bought him.

Is your horse to travel all day over parements that will speedily develop every tendency he may have to weakness in hoof, bone or muscle?

Do you propose to haul heavy loads over ffinty and unyielding roads, up hill and down, that will test the texture and condition of hoofs and shoulders to the uttermost ?

Are you a dweller on soft prairie or bottom lands, where for three-fourths of the year it is a matter of indifference if your horse be shod or not, and where the changes of elevation are so moderate that with decent use defects of shoulder and loins need not soon become apparent?

If the former, you may at once reject an animal from whom you 
could abtain years of valuable service in the latter, albeit recklessness and ignorance will use up endless horseflesh under the most favorable circumstances. Contrary to some received local opinions, it should be noted that a light and wiry horse should never be put to heary or steady work over soft and yielding ground, and a beast of any make should be.allowed to take his time if he is expecteil to last through the season.

Supposing these points so far settled that your head is clear concerning them, it would be well to give a few moments' attention to the nature of your facilities for feeding and stabling, for some horses will thrive well under treatment which would speedily destroy all the usefulness of seemingly much moro valuable animals. Is your supply of feed good, and can you afford variety and chango without too great expense, or are your surroundings such that a mule-like toughness of constitution is almost a sine qua non? If . the latter, beware how you look, out for too much "blood" or too great a delicacy of habit. Imported animals and their immediate descendants require too large an amount of care, jockeying and laborious stabling, to be profitable property for working farmers, especially in comparatively new countries. If you don't believe it, try a few experiments and report the results to the writer hereof. The history of a horse or two will be likely to prove quite sufficient, and experience is the most costly of all schnolmasters.

But we have not yet asked all our questions, odd as it may seem, anl our next immediately concerns yourself :

"That do you know about a horse, any way?"

Perhaps this should have been the first inquiry ; at all erents it is by no means the least important one, as will shortly be seen.

Are you good for anything to train a horse? That is, will a horse be apt to increase in value under your management, or do you only piopose to buy ore and use him up? Nine men out of ten leave a horse worth less than when they took him, while the wise and skillful tenth man gets his horse-work for nothing by reason of the way in which he developes a!l that is good and works out all that is bad from the beasts that come under his hand. The point for us to make, however, is this:-if you do not know enough to train a horse and improve him in the training, you must look out for one whose education has been properly attended to by 
some one else, and you must especially avoid purchasing any animal that has been ruined in the bringing up by some other ignoramus. If you are very ignorant you had better buy a horse whose age has so confirmed his habits, whatever they may be, that he is likely to be proof against any further blunders on your part, and you may expect him to wear stubbornly away under your mismanagement and allow you to learn something at his expense which will be of use to you in your next experiment.

If, on the contrary, you have been brought up among horses, and suppose yourself to know something about them, you can perhaps afford to pick up young stock and keep them until thes are old enough for use. Say you get a likely four or five year old and gradually work him in, according to his build and temperament, until he is fit for hard work. This is by far the amost economical method of purchasing, other things being equal.

The number of those who only.buy horses to use them up, as so much mere dead capital, is so very large that no intelligent buyer need fear the want of a market for anything that he has done with if he has only taken decent pains with training and other ordinary considerations. Almost every man who reads this will be able to call to mind some shrewd fellow of his acquaintance who always has good horses, never overworks them, and yet who so manages that his stable actually costs him nothing. Men like to buy of such fellows, for their equine pupils are apt to graduate with undamaged constitutions and singularly free from the vices superinduced by bad driving and other points of foolish training. That they are the exception rather than the rule is only another warning and a good "footnote" to this part of our chapter on buying.

It may be taken for granted that each individual buyer has settled all the points which we have raised in a manner most agreeable to his own personal vanity. If there is one point upon which every human being is thoroughly self-satisfied, it is assuredly his knowledge of horseflesh and his capacity for making the most of it, and, in any individual instance we should positively decline to argue the case. This therefore being settled, with all the other questions raised,

What is your market?

Are horses plenty or scarce with you? Do you live in a horse raising country ? are the animals nearest you for the most part of 
one stock, bred to the peculiarities of the climate and the work, or can you have your pick of a large variety of breeds? As a general thing it does not pay to go too far from home to find the animai you are after, for several reasons. You are more likely to be sure both of the pedigree and individual points of a horse raised by your near neighbor, and the guaranty you get is more likeiy to bs worth something. It takes a pretty good horseman to go arourd the country and "pick up bargains." Most of the men who try it, leaving out the professionals and the Methodist "circuit riders," get badly "picked up" themselves as a general thing. If you can get a horse that you have had your eye on since he was a yearling, and whose dam has taken your fancy for shape, endurance and general good qualities, that's your best chance, unless the training has been careless or cruel. Don't buy some men's best colts for any money: a horse is heir to the good qualities of his sire and dam and to all the bad ones of the human animal who raised him: he will suck in everything but politics and religion from his master. Supposing that you have had your attention called to an animal with which you are not altogether familiar, and that means any horse besides your own especial pet, you are at once called upon to settle many questions which are of the utmost importance in buying a horse and you may summon all your keenness and good judgment, for you may take it for granted that if you do not there will be a double sale of the beast and his purchaser. The best of men have a weak spot that shows itself in trading in horseflesh : a man can't even tell the truth about a horse when he is giving him away. 


\section{CHAPTER THIRD.}

\section{IOOKING AT A HORSE.}

External peculiarities-Color of coat and feet-Condition of the coat-Taking him out of the stable-The age of the horse-The mark in his teethThe head and neck-The ear-The eyes-The nostrils.

If now we suppose that you have made up your mind fully as to the answers you would give to the questions propounded in the previous chapter, and that you propose to depend upon your own judgment in the matter, we may enter at once into a discussion of those points and qualities, good and bad, which are or may be considered the general property of all borses, of every breed and race.

The question of legal guaranty, and what constitutes technicai unsoundness, will be discussed hereafter in its proper place, but it may be taken for granted that the absolutely perfect horse has never yet been offered for sale. Each individual animal has his peculiarities, virtues as well as vices, beauties as well as defects, natural as well as acquired, and it is the business of the buyer to ascertain them for himself, so far as may be. With some changes, bearing upon special adaptation to different uses, nearly the same rules are applicable to all descriptions of horses, and those changes are such as can hardly be made in a treatise like this. Let us suppose, then, that the horse you are after is an ordinary roadster: suitable also for farm work, not too heavy, and from fifteen to sixteen hands high.

If you have gathered any prejudices about color, white feet, etc., from old proverbs ör doggerel rhymes, you may as well drop them. In this country, however it may be in others, color is a mere matter of taste, except where it is a mark or indication of some peculiar breed. The relation between different shades and markings and the temper, endurance and other qualities of horses, has its existence only in the fancy of old-fashioned dealers. This notion has been hard to uproot, and half the wiseacres in the country today are inclined to look askance at a horse with three white feet. 
Howerer, taste is something, and a piebald horse, what they call in some places a "calico," or a muddy coated or "flea-bitten" animal, aud some other eccentricities of shacle, are not so attractive to the eye, nor are they generally so saleable, as a bay, a chesnut, or some other bright and agreeable color. The chief value of the appearance of a horse's coat, at first sight, is as an indication of his breed and condition. In warm climates the skin of the horse becomes thin, and his hair short and fine, while in coider regions the reverse is the case. The Arab or other tropical animal developes a sensitire cuticle with a coat that becomes as glossy as satin with good rubbing, while the "sheltie" protects himself against his long winters with a coat as thick and shaggy as a young bear's. Something analagous to this takes place in all the central and northern part of the United States, and every horse regularly puts on and off his winter clothing. If a horse is bought while he is moulting or "shedding," the roughness of his coat is not to be counted against him, nor should he have in January the same smooth and shining surface as in June, unless he has been too tenderly and warmly stabled. A "staring" coat with the hair standing out in different directions from a hard, dry or unyielding skin, is a pretty sure symptom of something internally wrong about the horse, and should at least lead to a more thorough inquiry.

Examining the skin and coat, however, requires that the horse should be touched, and we are not ready for that yet. Before going at al: inio minute details, such as we shall explails hereafter, have your proposed purchase led out of the stable and take a good long look at him, at a distance of several feet. It may be he has already been brought out, but the buyer had better sse it done, and note if the horse comes out readily and kindly, without making any trouble about it.

The first look at a horse should be when he is simply standing still, in the position which he assumes of his own accord, and that should be firm and easy, with his legs well under him, ass without showing any disposition to favor or relieve of his weight; either of his feet. Should he seem to do this latter, or should he incline to sprawl out with either hindlegs or forelegs, there is sure to be a good reason for it, and you had better look close before you buy him.

If, after a general examination, the animal seems to be anything 
near your idea of your own requirements, your next business is to look for specific faults or defects, of which every horse in the wo:l:1 may be said to have either more or less. Most of these are sucil : $:$ are not covered by any ordinary guaranty, or they may be as : $:$ in the form of incipient tendencies, such as will escape a carelesis eye, but which nevertheless affect the value and usefulness of the horse.

Faults of training and education you can look for afterwards, but your first care must be for the body of the animal himself. This is a beautiful but very complicated machine, whose several parts are all so necessary, one to another and each to all, that defect or disease in any portion of the powerful frame detracts to a greater or less extent from the utility and durability of the whole. Every part of the animal should therefore be scrutinized with the utmost care, and no loud assertions of owner or bystanders should be allowed to counterbalance the testimony of your own eyes and fingers.

To facilitate the explanation of much that we have to say, we give, at the end of this chapter, a sketch of the skeleton of the horse, showing to what sort of a bony frame the muscles and other organs of which we are to speak are attached.

The first question to be asked, and the one most apt to be answered incorrectly, is concerning the horse's age. To be sure, you can have him warranted at the age which it pleases his owner to state, but it would be much more satisfactory to be certain about it, and this is not often possible, even for experienced horseme:a, except within certain ages, however strong may be the assertions to the contrary. The skill of European dealers in "making up mouths" for sale is frequently such as to deceive any but the best judges, but the wretched art is less practised in America.

Apart from the general appearance of the horse, the surest marks of his age are to be found in his mouth, and here the special ex. amination of the buyer generally begins.

The teeth of horses, like those of men, are coated with an exceedingly hard substance called the enamel. This enamel covers all that part of the tooth above the gum and is supplied in an extra quantity at the top, as if to provide for being worn away in use : in the centre, howerer, upon the top of the tooth, the enamel seems to be bent inward and sunk into the body of the tooth, so 
as to form a little hollow, and, as the inside and bottom of this hollow become blackened by the food, they constitute what is called the "mark," and, as the surrounding ledgo of enamel wears away, its gradual disappearance enables us to judge, approximately, the age of the horse. Ignorant men speak or the "filling up " of the hollow in the tooth, but this is an error, the disappearance of thie "mark" is caused by the slow wearing away of the extra supp!y of enamel and other materials of the tooth.

In this country there is generally very little reason for any attompt at deceit in the age of young colts, and the consequences cannot be very material, even if the cheat is successful. At twelre months old, the colt has twelve front teeth or nippers, all of which are afterwards displaced by the permanent teeth: This treatise is not designed for the use of such professional dealers as desire to speculate in the purchase and training of miscellaneous colts, and they must know their business well enough to distinguish between yearlings and two-year olds, or they had better retire. At four years old, however, the hor'se's mouth will be still imperfect. The second growth of teeth have got a good start, and some of them are perfect. The two teeth in front, in the centre, will be quite grown, with the sharp edge of the enamel slightly worn, and their " mark" wider and fainter in consequence. The next pair, right and left, will be well up, but small, yet with the mark deep and daris. The corner nipyers will be flat, and with a fainter mark than the centre ones. They are as yet first teeth, the second not coming for some months later. With the grinders an inexperienced buyer has very little to do, as they will only confuse him. At fire years, at which age we are too much in the habit of putting our horses to hard and regular work, the teeth are about complete. The corner nippers, the third pair of second growth front teeth, are fully developed, with a deep and irregular "mark," while the other two pair show signs of wear. The centre teeth will only show a black spot on a nearly smooth surface. The minor tolkens, indicating more closely the changes between four and fire years old, can only by judged of by men whose practical experience does not call for "book learning," and, if a case comes up for decision, the only way is to take the counsel of an expert. No teeth are shed after five years of age.

We havo thus far spolien of the tecth in the lower jaw only, as 
being those first and most readily examined. They also exhibit the mark more plainly by reason of the fact that they are more rapidly worn, and lose it first. It should be borne $\mathrm{i}$ mind that this wear of which we speals, although it slowly destroys the cenint, the enamcl, the dentine, all the component parts of the tooth, does not at all decrease its eleration, for the teeth of the horse grow continually, and are longest in extreme old age. The upper teeth wear away more slowly, and an opinion, of more or less doubtful value, can often be based upon their appearance for a year or so after the lower teeth cease to be a guide. All this, however is subject to such changes from accident, food, and the indiridual Labits, and history of the horse, that his age, like that of ladies, may be politely set down as " uncertain."

At sic years, however, the "mark" will have so far disappeared from the two centre front teeth that only $\dot{a}$ discoloration remains at the bottom of what will then be the very slight bollow. In the next teeth the mark is short, wide and faint, and in the third pair the enamel is worn to a greater evenness, but the mark is clear. Note carefully if the tushes and grinders are well grown, even and. in good condition. The teeth of a horse have a great deal to do with his health, as the proper management of his food largely depends on them.

At seven years the "mark" has nearly if not quite worn out in the four centre front teeth, and the tushes are more round and even than in younger horses. At eight years the "mark" disappears from all the six "niplers," or front teeth, in the lower jaw, thotgh traces of it may be found in the upper teeth. These latter fumish a few hints for some months longer, but, generally speaking, a horse may be said to have "lost his mark" with the close of his eighth year, and from that time forward his mouth is only of use by way of noting if his teeth are in serviceable condition. The tricks of the trade by which marks are counterfeited are not much in use in this country, and can only deceive the careless or the inexperienced. It is surprising, however, to find what an enormous proportion of the "aged" horses in the world are between eight and nine years of age. One would think it all but impossible for a horse to pass his tenth year.

There are signs, indeed, by means of which rery keen and practised judges are enabled. to form an opinion of some kind, up to 
the rery last, but as no two of such "experts" hare ever been known to agree, either as to principle or application, we need not trouble ourselres to put their gathered nonsense into print-it would not further our pu:poses a particle. Eren in a liorse known to be young, the buyer should note if there are ans special iregularitics of the teeth, if they are grown evenly and come well together. A set of teeth that have a scattered and uneven look are sure to diminish the comfort and usefulness of their owner.

In examining the horse's mouth, pay attention to the gums and the tongue, and see if they are in a natural and healthy condition. - Scars of laceration by the bit may indicate bad training, or they may speak for an ugly temper, while cankers and bladders are pretty sure evidence of defective feeding, or an unhealthy condition of the animal.

We hare declined going more minutely into a description of the teeth, for the reason that the wear in different horses, of the same breed, and in different breeds, is by no means uniform. Food also has its influence, and "crib-biters" especially remove the mark rery fast. No amount of written description will make a greenhorn a good judge of a horse's mouth, and experience itself affor ds only an approximation to certainty. Take any two horses, foaled the same day, and at any given time in their after lives their teeth will present such different features as to lead to varying judgments of their precise age, and there we may leare a rery much rexed question.

If now you have learned all you can from your examination of the mouth, step back a moment, and look at the whole head.

IIow does it compare with the body ? Is it in good proportion, well held up and symmetrical? Or has it a heary, over-loaded appearance, as if it would be something ugly to carry on a long march? Whatever the breed may be, racer or dray-horse, the head should be in keeping with the size of the horse, clean and well-made. IIalf the vicious biters, bad-tempered, unmanageable brutes with whom our own experience has brought us in contact, hare been "Roman-nosed," the face describing a curre from the middle of the forehead outward to the muzzle; the other half havo lreen too much "basin-faced," or the reverse of the Roman. A decent medium between the two serms to he nature's best design for good temper, although some of the best and toughest animals 
will occasionally turn up with a "bad face." The forehead should be broad and flat.

The $e a r$ is valuable first as an indication of Glood, and then of disposition. It should never be disproportionately large or shaggy, and a limp, lop-eared horse will cost his purchase money in whips. Prefer an erect, rather thin, intelligent ear, without too much of nervous motion in it. The latter is apt to indicate peculiarities of. disposition that are quite inconsistent with comfort or safety to the rider or driver. A good, tapering muzzle, proportioned to the jaw, a face broad between the eyes, and not disfigured by those deep hollows over the eyes which surely indicate old age or bad condition, a pair of good, honest ears, and the buyer may confidently proceed to an examination of those useful organs, the cyes.

In the first place, are they both alike, in size, color, expression, and brightness? If they are not, something is wrong. The eyes of the horse are attached to muscles which are fairly bedded in fat, and as age comes on, this fat is absorbed, so that while the eyes of a young or middle aged animal are full and prominent, they afterwards acquire a contracted and sunken appearance. Disease will sometimes produce this effect.

If then the eyes of your proposed purchase are full, bright, prominent, and both alike, note if they are quiet and pleasant in their expression. Look out sharp for a horse who shows much of the while while he is looking at you or about him. He shows that most when he is glancing backward after a chance to do mischief, and if you are in search of a safe and quiet beast, you don't want that one, particularly.

The eye of the horse, as of all other animals, is a most delicate organ, likely at all times to sympathise promptly with the general physical condition. It may also be temporarily under the influence of mere casualties, the effects of which will soon pass away, but as he will hardly ever be offered for sale under any such circumstances, the buyer may take it for granted, that any apparent defects, which he may discover, are the indications of more or less important diseases.

The protuberance, or cornea, of the eye, should neither be flat nor too prominent, but it should not have any tokens of cloudiness or "speck." Put your head down by the horse's cheek and take a look across the eye, as well as dead in front of him. You cannot, 
of course, pretend to a scientific examination, but there must be some fault in your own eyes if you cannot distinguish the orlinary signs of local inflammation in the eye or its surrounding muscles, or eren the indications of bad temper. The dulness consequent upon internal disease is so readily removed by administering certain stimulants that the eye is a general tell-tale of such matters only when the seller has been guilty of unaccustomed neglect, and the buyer must look further for information which, in a state of nature, would be readily furnished by the sensitive organs. If the eye is not "all right" the horse may still possess a good deal of valuc, and it becomes simply a matter of private judgment how far the specific defects discorered interfere with or diminish the value of the animal for the work to which he is to be put. Of this, however, be sure, it is not likely that the sight of the horse will improve as he grows older, and that although the present disease nay be temporary, it will leave in the organ a disposition to a repettion of the same.

Do not leave the horse's head until you have glanced up his nostrils to see whether or not they are red and inflaned by the action of catarrh or some other disease which has been temporarily checked or hidden for purposes of sale. A brief examination of a few healthy horses will tell you how the internal membrane ought to appear, and you must be your own judge, having reference to the general color. If there is any mucous discharge that is about all you want to know,-don't buy him. The nostril itself shouli he wide and well opened, that the animal may breathe easily, and its relative firmness or coarseness will be according to the breed. The draught horse will show a degree of coarseness suited to his general organization.

The jaws should be strong and wide apart at the base, to gire full play to the breathing apparatus, and so that the head can be more elegantly set upon the neck. This has its effeat, too, upon the readiness with which the bit and rein can be answered by the action of the head. 


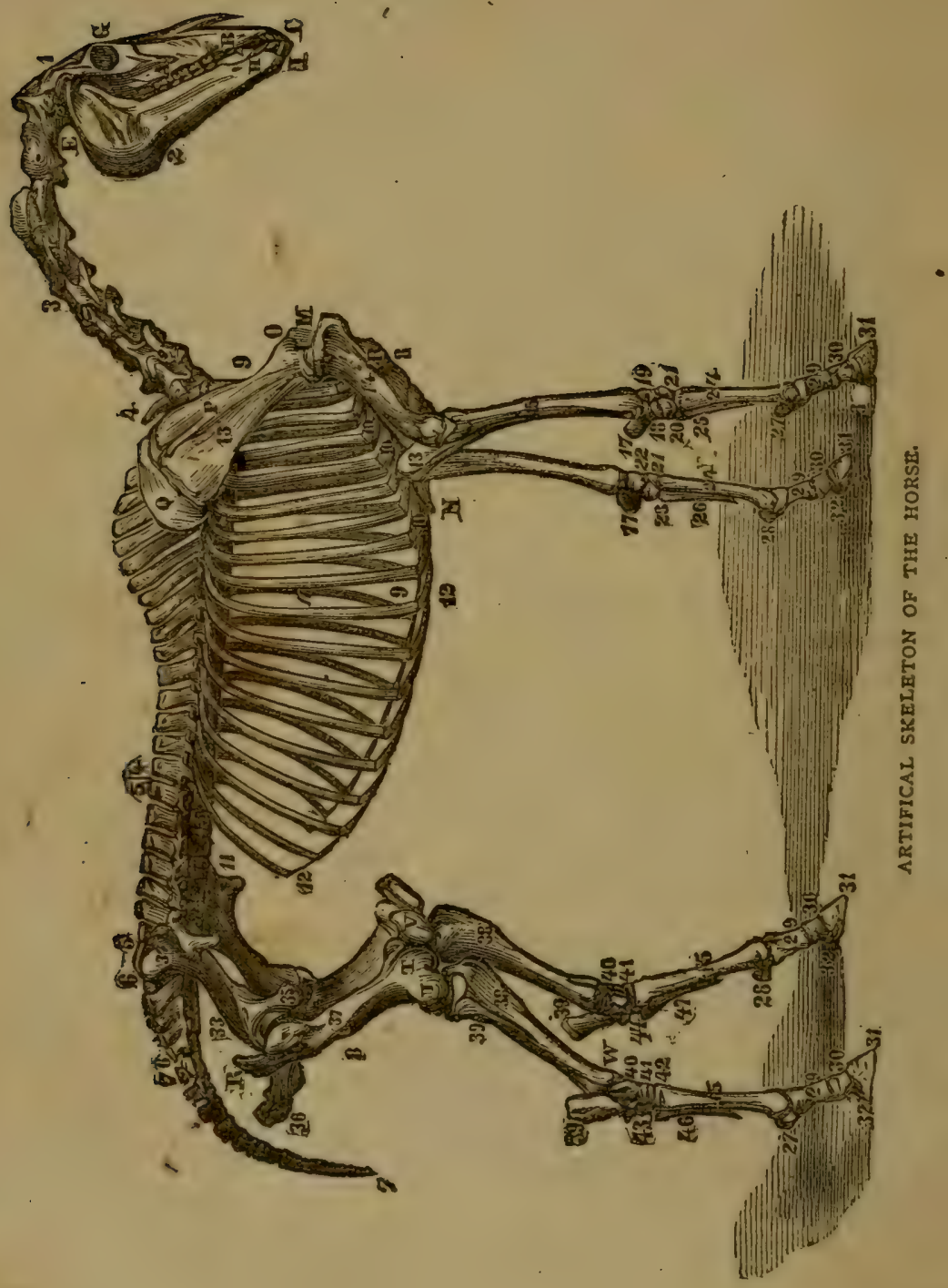



A. Molar teeth.
B. H. Canine or tush.
C. I. Incisors.
E. Atlas.
G. Orbit.
M. Cariniform cartilage.
N. Ensiform cartilage.
O. Coracoid process of scapula.
P. Spine.
Q. Cartilage.
R. Trochanter Major.
S. Trochanterian crest.
T. Trochlea.
U. External condyle.
V. Patella.
W. Hock joint.
1. Cranium.
2. Lower jaw.
3. Cervical vertebra.
4. 4. Dorsal vertebrx.
5. 5. Lumbar vertebrx.
6. 6. Sacrum.
7. 7. Coccygeal vertebra.
8. Sternum.
9. 9. True ribs.
10. 10. Cartilages of true ribs.
11. 11. False Ribs.
12. Cartilages of false ribs.
33. Scapula.
14. Humerus.
r5. 'Radius.
16. Elbow.
17. Os Pisiforme.
$\left.\begin{array}{l}\text { I8, 19. } \\ \text { 20, 2I, }\end{array}\right\}$ Carpal bones.
$22,23$.
24. Large metacarpal bone.
25. Outer small metacarpal bone.
26. Inner small metacarpal bone.
27,28 . Sesamoiid bones.
29. Os suffraginis.
30. Os coronx.
31. Os pedis.
32. Wing of pedal bone.
$33,34,35,36$. Os Inuominatum.
37. Femur.
3S. Tibia.
39. Os Calcis.
40. Astragalus.
$4 \mathrm{I}, 42,43,44$. 'Tarsal bones.
45. Large metatarsal bone.
46. Outer small metatarsal bone.
47. Inner small metatarsal bone. 


\section{CHAPTER FOURTH.}

\section{MORE ABOUT BUYING A HORSE.}

The horse's neck-Poll-evil-The shoulder and its marks-The chest-The foreleg and knee-Knee-sprung and splints-Tied in below the kneeWindgalls.

THE neck of the horse is composed of a number of powerful muscles, tendons, etc., arranged upon and shaped to a series of seven bones or vertebra (see plate), and it must be looked at sharply by the purchaser. It must be exactly proportioned in length to the size of the horse and not too slender. Those proportions which are apt to strike the eje as most beautiful are also generally the best for strength and health. 'I'he mane will accord with the breed of the animal, thick, coarse and shaggy in some, thin and fine in others. A very objectional feature, on many accounts, is what is called ewc-neck, - that is, the upper line of the neck is concave rather than convex, and the unnatural shape interterferes both with beauty and usefulness, and is believed to includo tendencies to throat disease. The neck should curve gently from the withers to the ears, and the head should be set on fairly and squarely: it should be thin and clean at the head, strong and muscular at the withers, or the horse will neither carry his head well or be a tough and durable animal.

The last bone in the neck, joining it to the head, is called the atlas, and just at the juncture there is a liability to disease which we shall speak of hereafter, but which may be temporarily concealed, and which the buyer must look for. This is "poll-evil," and a horse with a running sore, or even bad scars, showing that a sore has been on the top of his head, at the juncture of the neck, is not a horse to pay much money for. There are other diseases of the neck and the organs which it contains, but they do not show externally, as a general thing, and we will pass on to the shoulders.

The shoulder of a horse seems to have been expressly adapted by nature to withstand the pressure of the collar, and it will . 
answer that purpose marrellously well, if the necessary human inventions and appliances are properly devised. Whatever the breed of the horse may be, anything approaching to a straight or perpendicular shoulder is practically a malformation, and should be accounted as such, for it materially detracts from his ease of action and endurance as a saddle horse, as well as from his power and ready application of force when used as a draught horse. The rery heaviest diaught horses, however, seem to form an exception to this rule. There are such things as a shouider too slanting, and withers too high, but they are not common.

Here, too, in this external survey, begin to look for traces of bad harnessing and orer-work, in the shape of "collar marks," scars, white hairs and other such tokens. The shoulder-blade should be broad and flat, and in an animal designed for the saddle, or for light work, may be ever so lean, while in one which is to pull in harness, with heary loads, it should be well cushioned, and protected by strong muscles in front. A glance at the shoulder of a dray horse will show, approximately, how this should be.

Breadth of chest between the shoulders, looked at from the front, is a very excellent thing, for it betokens that the lungs have room for fair play, but perpendicular depth, and the diameter at a drop-line from the withers will tell even more in that direction, for many very good horses have a narrow-chested look to a superficial observer. In order to get a notion of the present condition of the shoulder, the horse must be mored along a little. If he lifts his forelegs freely and easily, eren if he limps, any fault he may have forward is not likely to be in the shoulder itself, but must be looked for lower down. The reason is that the shoulder bone is detached by muscles only, and he cannot have free play of his leg if these muscles are not all right Temporary sprains of these muscles, from a fall or from overwork, are so easily remedied, that a horse is not apt to be offered for sale while suffering from one, but much more serious difficulties are apt to be charged to this account, that they may be made to appear of less importance.

We may pass, for the present, from the consideration of the shoulder itself, with the observation that the heavier the horse, and the more entirely he is designed for heary draught puiposes only, the less important becomes the obliquity of the shoulder, as tho 
Tatter provides more especially for activity and ease of action. Indeed, the best Flemish dray horses show a degree of uprightness inadmissable in lighter and more active breeds.

Note next if the muscles of the forearm, beginning with its upper attachment, are broad, prominent and well developed, and that each separate muscle, considered by itself, has a look of being short as compared with the length of the forearm, and that the lat-. ter is long and well proportioned.

And now we come to that complicated and important structure, the knee, and here the buyer must pause for a most careful and considerate scrutiny. Take a side look first. Does the limb curve forward, unnaturally, at the knee? Then some excessive pulling, or some untoward accident has been at work, and the horse is " knee sprung:" not exactly ruined, but so badly damaged, that his price must be șeverely taxed for that defect. City horses, drawing heavy loads over hard pavements, or those whose labors have been in hilly districts, are specially lidble to this deterioration, while it is much less common on the prairies or in other level regions.

Now step around in front. The color of the hair at the knee is apt to be darker than the general shade of the horse. Three times out of four, dark enough to "mark him," enabling the observer to look out the better for the scars and tufts of white hair which indicate "broken knees." A horse may have been wounded in the knee by some accident-note if only one is scarred-or by some fall, from which he may have entirely recovered, but, if his knees are at all disfigured, don't buy him until you have taken another look at his eyes, and have otherwise assured yourself, by trial, that he is not an habitual stumbler.

The knee should be wide in fiont: it can hardly be too wide, whether compared witis the arm above or the shank below, as it is a sort of "plate," designed to receive the insertion of powerful and severely worked muscles. A thin-kneed or bow-legged horse cannot, by any possibility, be safe, strong or enduring. If a scarred knce is accompanied by an upright shoulder, the horse may at once be set down for a constitutional stumbler.

If your eyes are keen, aird you have carefully examined the leg thus far, though you have done it in half a minute, you have now arrived at a part of the animal which you must not by any means neglect. From the knee to the ankle, the horse's leg is composed 
of three bones, the large one in front, called the camnon or shank bone, and the two smaller or splint bones, behind. Tiewerd from the front, tinis part of the lez shenil be siraight and thin, for it lims little or no flesh, but looked at from the silde, it should be deep ind strong. I Look around on the insile of the leg, and see if the smaller bones are well made and clean, or if they hare thrown nut any bony protuberances or "splints." These latter are apt to interfere with the action and usefulness of the horse. T'he nearer they are to the knee, or the more "inside" they grow towards the lar se bone, the more likely they are to lame the animal. Splints come and go, and are more frequent in young and middle-aged animals, whose exuberant constitutions furnish more bony matter than nature requires. Some old roadsters that have been badly crippled in this way, at last absorb or outgrow them. The eye itself may easily be deceired, but after feeling a few clean legs, the fingers will readily detect the undesirable deformity.

The horse's leg is a curious mechanical contrirance, and just below the knee is a tremendous ring by which the muscles are kept in place and through which they play, like ropes through a puiley. If, howerer, this ring is contracted, so that the ler looks thin and deficient in lateral depth, the muscles cannot work frecly, the horse is "tied in below the knee," and can neither be rery fast or enduring. He will tire out too easily and be liable to sprains and sucldm lamenesses.

Low down on the leg, near the pastern, both eye and finge:s must search for slight swellings, soft or hard, and the harde: th if are and the nearer the fetlock, the more they must be regarde?, for they are what are denominated "windgalls." As a general thing they are no tolkens of unsoundness, and they come and go on all horses, but some are more prone to them than others, and they are apt to cause temporary lameness. At times, from bruise, ill ireatment, growth, or inflamination, they become unsightly and even dangerous.

The pasterns and feet are so nearly alike in their peculiarities and tendencies for all four of the legs, anit of sisch particular inportance, that we prefer to leave them undil the i.2:t, and relums now to the consideration of other features of onr contemplated purchase. The horses are few, comparatively, who will answer satisfactorily every question which the er: of the purchaser he: even thus far asked of him. 


\section{CHAPTER FIFTH.}

\section{EXTERNAI SIGNS OF DISEASE.}

The body of the horse-Form of back and barrel-Flesh and the want of itFistulous withers and other sores-The loins and haunches-The hock and its diseases-Windgall, Curb, Capped Hock, Spavin, Stringhalt, Mallinders, \&r. -Feet and Ankles.

THE body or "barrel" of a horse contains his heart, lungs, stomach and other vital organs, and there must be room in it for them, or the most perfect limbs in the world will avail him but very little. It is deficiency here, even more than defective limbs, that produces what is justly condemned as a "leggy" or "weedy" animal, and an undue excess produces a beast that is more likely to win celebrity as a feeder than in any more useful direction.

If you have any knowledge of how the horse before you has been kept or what have been his chances for work and food, you will be better able to form an opinion as to whether his condition as to flesh is for or against him. As a general thing horses offered for sale will be previously brought to look well, outwardly, and due allowance must be made for that. It is no great trick to put the most worthless brute in good shape for the butcher, if that gentleman was after him, but mere fat is no indication of health or value. Better he should not make too prominent a show of flesh, for if he does you will have to work it carefully off before you really know what you have purchased. If you touch him on the ribs, however, fat or thin, see that the skin plays loosely and easily over them. A great deal is said, unnecessarily, about the shape of the ribs, but malformation is rare and only an expert can get much information from them.

The withers of the horse, which shonld be high, and his back, again furnish signs of the kind of work and treatment he has received, while spur-marks on his flanks may be indications either of his own temper or that of his rider, indifferently. Look out especially for sores or scars thereof, on or near the withers. If the 
horse has "fistula," a ruming sore, in that locality, don't buy him, aud if the scar looks as if he once had one, remember that you have no guaranty against the old evil breaking out afresh.

Just back of the withers of any well porportioned horse thero should be a moderate depression, and from here the line of the back silould be nearly straight to the loins. Horses whonse backs exhibit more of concarity are said to be "hollow backed," and unusual height of shoulder and haunch sometimes gives the appearance where it does not exist, but in either case this feature is not to be considered a defect of itself. On the other hand a "mule-backed " or "rail-backed" horse has no business at all with a saddle on him, and is not always as valuable otherwise. As to the length of a horse's back, authorities differ. Our own opinion would be that a moderately long barrelled horse is preferable for general work as having more room for the play of his muscles, prorided his length is in proportion to his perpendicular depth at the chest and his transverse breadth at the loins. If this is otherwise, a heavy weight in the saddle or a hard pull behind him will break him down, for his length exerts a lever power. A round, well-developed barrel, not too long, and without any appearance of paunchiness, is apt to answer most purposes of work and health to the best advantage. Do not carry the notions of "length" too far, as short-bodied horses are generally strong, hardy and serviceable, and disproportionate length is almost a sure sign of either slowness or weakness. A "hog-backed" horse, with a convex spine, has mistaken his vocation, he would have done himself more credit altogether as a hog.

The loins of the horse can hardly be too broad and strong, for on these depend both his pulling and carrying power. Fat will sometimes make them appear better than they are, but they must be looked to, narrowly. If they are thin, weak, or at all misshapen, there is no hope for work or usefulness that it will pay to invest much money in. Mere saddle galls, bruises and things of that kind, are so easily to be cured, as a general thing, that it is only important to note if they have developed any ulcerous tendencies, such as would be apt to render them difficult to treat, though of course it would be very desirable to have your purchase clean of them.

The shane of the horse from the loins to the setring on of the 
tail differs materially in varions breeds. In some, as in the English hunter and the Flemish dray horse, the direct line is a gentle curre, or sometimes almost straight, while the American trotter shows an obliquity which seems almost a deformity to some of our brethren from over the water. This therefore may be put asicle as of minor importance, but the breadth of the haunch is vital to the power of the animal, since the great muscles which are to lift and jush him are to be attached to these bones, the largest and strongest in his whole body. Rounduess and beauty are very well in their way, but in this country our best horses scems to develop, very often, a remarkably angular and ragged looking hip, which makes up in efficicney what it loses in good looks. This will show itself particularly if the animal has been hard worked and is a trifte thin in flesh.

And now we are compelled to be a trifle technical. Turn to our cut of the skeleton of the horse and note the position of the hip and the stifle-joint: the large bone between them is the fcmur, and in order to secure speed, or a free and easy motion of the hindleg, especially in heary ground, as in spring plowing, it should be long and strong in proportion to the size of the horse. From the root of the tail to the point of the stifle-joint, flat measure, the distance should be about twa feet for a horse between fifteen and sixteen hands high. If measured orer the surface it will naturally be nearly three inches more, according to the swell of the muscles. A strain here is not very common, but is sometimes caused by violent exertion or falls, and the horse will show it at once on being moved off, by faroring the unsound side, or eren by a positive limp.

The next bone below is called the tibia, and this also should be long and well set, corered with well developed muscles. If the thigh has a thin and lanky look, especially from belind, or if the two seem to spread below the anus, learing a hollow there, the horse will speedily show wealness when he is put to heary work or rapid motion; his constitution is probably bad.

The hock (see cut) is about the hardest worked joint in the whole skeleton, for its size, and nature has framed it and strengthened it accordingly, surrounding it with powerful tendons and muscles, but for all that its machinery will sometimes get out of order, and the buyer must have a close look at its condition. Ninetenths of all the lamenessas in the hindleg are ant to come in here. 
Near all joints there are placed what we may call "little barss", containing a mucous fluid for purposes of lubrication. If these become inflamed or enlargel hy over work they will show themrelves. On the forelers they make "wimlgall:," lut if just almeve the hock, on either side, they constitute "thoronghinn," which is not exactly unsomidness, but should leat you to incuire how it was they were brought out. We shall lave nure to say of them"lereafter.

A more important matter is "curl)." Three or four inclies below the point of the hock, at the hack, violent or sulden exe:tion will sometimes cause an enla:gement. Either the ring-like ligament which ties down the tendons is strained, or its membranous sheath, and lameness is the result. Even if the swelling is so slight that you overlook it from behind, and it only shows a little at a side riew, it will be slow to cure, apt to return, and will surely grow worse if the horse is put to hard work. Some breeds of horses are more liable to curb than others, and it may almost be considered hereditary. Look carefully therefore for even the slightest symptom of curb.

Another thing to be looked for is called by some "bog-sparin," and by others "blood-spavin." Look on the inside of the hock for something like a large windgall. There are reins between this swelling and the skin, and the flow of blood is so impeded as to interfere seriously with rapid motion. It will canse slight and frequently returning lameness, but does not destroy a horse for slow work. It is decirled unsoundness in any horse, and is one of those dificulties that, eren if apparently cured, will not stay curerl. But you are not yet done with the hock. A most dangerous and troublesome malformation is " bone-sparin," and you may look for it on the inside of the hock in front. It is a growth of bone, showing itself alove the proper level of the hock-joint, and an inexperiencer eye will detect it most readily by seeing if there is any differcnce in the extemalcont our of the two joints. The one which seems to be slightly enlarged is the one to examine more closely. The horse may not show any lameness just now, but he will surely do so in course of time, nor is the mere size of the growth any innlication of its ugliness. Some badly sparined loorses have a vatse deal of slow work in them, while others, in which the growth seems only to have bejun, are lane half the r the and unfit for 
rapid work of any kind. If you see a suspicious lump, have the horse moved suddenly and quickly forward and note if he "catches" any in raising that leg. The catching and the lameness may temporarily disappear" in work, but after rest the old stiffness will come back again worse than ever.

"Capped-hock" is a swelling, a sort of soft tumor, at the point, caused by some injury, such as the horse may give himself in kicking, and even if it is not accompanied with lameness, it diminishes the value of the horse.

Sometimes over work will result in permanent enlargement of the hocks without seeming to destroy the usefulness of the animal, but such horses are not to be relied on. You will never know when, or for what slight cause they will fall dead lame and be laid up, in the very midst of your busiest season. Don't buy so strong an indication that so important a joint has been weakened.

If there is a scurfy look at the bend of the hock, or a discharging sore, the stable management has been careless and bad. That is, mallenders, and is of no great account if the horse is otherwise sound, as it will yield to treatment, but it is of value as an indication of condition and usage, and must have its due effect on your judgment.

A very little motion will tell you if a horse has the "stringhalt," by the jerky motion of his legs. It is likely to disappear when he is warmed up; it don't actually hurt him, and if it is not too bad, he may have a world of hard work in him, but you can never cure it, and it will be growing worse with age. It takes away materially from the good looks of a horse, and the pleasure of using him.

Now, stand behind your horse, and see if his legs from the hock down, descend perpendicularly to the fetlock. If the hocks are close while the leg spreads out. and the toes of the feet spread likewise, the beast is "cow-hocked." He may be all the faster horse, for it gives him a chance to lengthen his stride, but he will be more liable to all the curbs, spavins and other difficulties that equine hocks are heir to.

A horse will not ordinarily be offered for sale when his legs are swelled, so that we need not linger longer upon the external symptoms likely to catch the eye. For some other items the reader is referred to the chapter on diseases and their treatment, and we 
will now pass to the consideration of what nay fairly be considered the most delicate, complicated, arimirable part of the structure of the horse, the one least understood and most abused, his "feet and ankles."

As a species of commentary on the various remarks in this and the previous chapters, it mas be said that any variation from perfect proportion in body or in limb should be thoughtfully considered, and any protuberance or unnatural appearance strictly accounted for. Such things as tumors, and the larger and more lisgusting sores and swellings need very little description, and are beyond the province of merely general rules and instructions. IIere we must leave even the most inexperienced to the exercise of a fair degree of common sense, but it is surprising how easily eren those who have been mueh among horses will allow themselves to overlook some of the most obvious defects in the feet and pasterns.

A brief study of the cut of the skeleton, as well as that of the "points" of the horse, especially if aided by an examination of the living animal, will force one or two important points upon tho consideration of the reader. He will see that the foot of the horse, from the ankle down, is small in proportion to what is expected from it; that the amount of pressure and pounding it endures is enormous: that any malformation must be of more importance here than elsewhere, and that wounds and bruises are likely to bo hard to reach or to heal. Ile will be likely, therefore, in looking at his proposed purchase, to search carefully into the nature of its "understanding."

The pastern or fellock, in old or over-worked horses, is apt to show signs of weakness by knuckling forward, unsteadiness or what is called "grogginess," and this tells its own story pretty well. Strain of the fetlock joint shows itself at once in swelling, tenderness and other signs of inflammation. It may be very slight or temporary, but the better way is to decline buying a horse so strained, as you cannot form a good opinion as to how far it will go.

Look on the inside of the pastern for signs of cutting or "interfering." Bandages, scars, or slight cuts will indicate the trouble. It is sometimes readily cured, but is oftener a troublesome vice, every now and then laming the horse, and making him very unreliavle. The same may be said of "over-reaching" by the hindfeet. 
The pastern bone should be cither more or Jess upright, according to the breed and general build of the horse and the uses to which he is to be deroted. In horses of a strong and heary make, designed for draught only, a greater uprightness is even clesirable, as tending to greater strength, but for all ordinary uses, the pastern should slant at an angle of forty-five degrees or more from the level ground. This gives a greater elasticity and springiness of motion, and is specially indispensable in saddle horses. The fetlock joint should be of good size and clean, and if there are any winclgalls they should be as far above it as may be. The lower pastern bone is smaller than the upper, and makes little external show. It completes the junction with the foot. Here also there is liability to sprains, but the horse will be pretly sure to show them on being moved.

One of the worst things that can happen to the pasterns, upper or lower, on forefeet or hindfeet, is the "ringhone," or as some varieties of it are called, "side-bone." Unless it is so bad that the horse is nearly ruined, you will hardly notice at first sight the bony protuberance under the skin, just above the hoof, or even higher on the pastern, that marks ringbone. It is more common on the hindfeet. The only advice to be given is to not purchase a horse with these bony lumps on his pasterns, but insist on having one who is not doomed to lamenesss, and sure to be worth less and less to you every month you keep him.

The next thing to look for is what the English call "grease," but better known in this country as " the scratches." It is an inflammation of the skin of the heel, geverally of the hindfeet, and may trouble the best horse in the world if he is not well cared for. The skin of the heel is different, in some respects, from the other skin, and it is so exposed and has so much motion that it must be kept soft and pliable. If it is healthy it will feel greasy and moderately cool. If not, if bad stabling has combined with exposure and frequent changes of temperature to produce local inflammation, there will likely be a crackell or chapped and swollen condition of the heel and lower pastern. It may be nothing but " chapperl inecls," or it may be "scratches," and the one surely learls to the other unless attended to. If there is any discharge of matter from the cracks, the legs will be sure to go on swelling, and the lameness to increase. There is no great difficulty, generally, in curing "scratches " 
but they are not to be entirely disregarded in forming your opinion of the horse.

What is ordinarily called the "hoof" of the horse is a sort of inny outside crust or box, about lalf an inch thick in front, and becoming thinner towards the heels. Tertically, the crust does not vary much in thickness until near the top, when it becomes "quite thin and is callerl the "coronet," and which is also different in its structure and nature. This hoof grows as your nails do, and in a state of nature will sometimes, where the ground trodden is soft and yielding, not giving wear enough, grow out and turn wrer, very much to the detriment and discomfort of its owner. "We witer of this has seen such a "turm-over" more than five inches long, on a wild pony from the marshes. This crust, how"rei", is not only of the utmost importance, but it is liable to disases and accidents. It is, if healthy, exceedingly tough and (lat:tic, but if kept too dry, or if internally inflamed, it becomes hilid and brittle and will chip off. Some horses are always liable to this in the summer, and are sometimes left without hoof enough Io nail a shoe on or to protect them from contusions. Many horses, also, are afflicted with sand cracks or splits, up and down the hoof, and these are to be especially looked out for.

Pusitively reject any horse who does not show a good healthy appearance of the "coronet," or at the junction, all around, of the foot with the pastern.

There are a great many superstitions about the shape and form of the hoof, varying in choice between the "mule-foot," or straight and small soled hoof, and the wide, flat hoof, and the hapyy medium is doubtless best, but the hoof changes its slape with argo and use, and especially with the aid of barbarous and bungling smiths. Your own eyes can tell you if it seems to retain a natural and healthy appearance, firm and strong, uncracked, unbattered or torn, and on lifting it up you can tell by eye and touch if the frog is cool and unfevered, and if there is no appearance of disease.

Over a very large part of our states and territories shoeing is mknown, except it may be in the winter, while the gromel is hard, and here the hoof has both a hetter aul a worse chance. B:atsu, for it is delivered from ignorant smiths: worse, for it is not proincterl sufficiently while poumling u!mon tho hard-bakerl roads of summer. The more reails there are buit, ant? the fimer they 
are made, the more absolutely necessary will shoeing become, but in forming an opinion of the foot of your proposed purchase you will do well to consider under what circumstances, in this respect, he has been raised and worked.

It is noteworthy that three-quarters of all diseases of the horse's foot are diseases of the stable and the horse-shoer, of which the animal knew nothing in a state of nature.

Of these, however, we shall have more to say in their appropriate place, and nust refer to those chapters for further notes on that subject, if any are needed. 


\section{CHAPTER STXTH. \\ TRYING YOUR PURCHASE. -}

Taking a guaranty - Get a clance to try the horse-Lead him home sourseliSigns of stumbling-The feed test-Promptness in taking home a bad horse.

Without descending into minute points, we have now indicated niost of the inquiries which a comparatively inexperienced buyer should make of an unknown horse. We have purposely diawn them in a somewhat rude and crude oucline, because that is all that would be of service to any but a man of such experience as' to require little or no advice, but we may well remark here, that a man who seems to know what he wants and where and how to look for manifest defects, and who also knows enough to keep his mouth shut and make no leading remarks, is much less likely to be imposed upon than others. Dealers will hesitate, naturally; to try the ordinary tricks of the trade upon him, and will even tell him, yoluntarily, many things that he desires to linow. He has now taken a fair outside view of his hor'se, as he came rrom the stable, and may be said to know that he is not absolutely worthless so far as external indications go. If he is immediately pressed to make his purchase and use his horse, this is about all that he can do, and he must have his guaranty drawn and singned and lead aw:ly his purchase. The "guaranty" should read somewhat as follows: "Received, July 18th, 1870, of John Jones, One Hundred Dollars (\$100) for a sorrell gelding, fifteen and a-half hands high, or the:cabouts, hereby warranted by me to the said John Jones or his assigns, to be only five years old, sound, free from vice, and quiet to ride and drive.

Petelr Suritn."

If only the words "warranted " or "warranted snund," are put in, the hor:e may be full of all vice and unfit for any work from bad training, and the worthlessness is not covered. A guaranty of a horse is in the nature of a common law contract and covers noihing whatever whioh is not clearly expressed. You may havo 
bought a living epitome of all the diveases horseflesh is heir to, and you are are without a remely unless your warrant gives you one. Otherwise there could be no market for unsound horses. The rule is founder in justice and common sense, though it perpetually leads to abuses by reason of the sharpness of some men and the stupidity of others.

If you have doubts of the solvency of your seller, insist that some decent man shall sign with him. As matters are now in the United States, your guaranty requires a stamp, according to thio laws at the time of your purchase, as it is a conditional promise to pay money at some future time. Fou can yourself affix the required stamp and cancel it The best gunianty in the world, howerer, is ariter all only a crutch to lean on, and a law-suit is as much to be shunned as a bad horse

If you are a respectable man of business, however, you have so timed your purchase that you are not compelled to be satisfied with the results of your hasty scrutiny, but can provide for a trial and have a few days leeway before finally closingr your bargain. Take warning that if the seller too strenuously objects to giving you a fair chance to test your purchase, there is surely a good reason for his so doing. If he knows his horse to be all right, he will be glad to have you also find it out. So then, if you can get your few days, do nut have your purchase harnessed or sadiled; let only the halter be on him; let no man follow or accompany ynu : and lead the horse cuietly away by yourself, and lead him as long a walls as you conveniently can. If he follows you readily and kindily, that is something, though it sometimes inclicates want of spirit, instead of thorough training. You must be the judge of that.

Do not stop to look back at your follower in a way to startle him cxcept once or twice to see if he immediately pulls back and braces himself to break away, as that is a sure sign of vice or bad training. 5.atl him along leisurely and quietly, up hill and down, and over as much rough and uneven grond as possible. Ite cannot fail to show whether or not he is a good walker, and that settles the question as to the soundness of his shoulder and hips. The chances are two to one that, if he is an habitual stumbler, that careless way of loose leading will give him a chance to show $i t$, which he will by no means neglect. IIe will also be sure to favor 


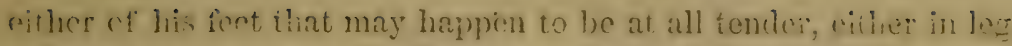
ar hoof, even nume eridently than if he was being urged forward by fear of whil or spur. If he is in the hahit of shying, however, he will not be soapt to show it now, for he is being led, not diven, and he has a horse's confidence in his liuman halter-holder.

In going through your gate or over your bars, you may lian a chance to guoss at defects in his eyes, by the cautious oi clumsy manner in which he fecls his way in.

Note if he pulls back at the stable door, or shows any sisirs of four. If he does, and there is nothing the matter with your stable, be very sure that he has had trouble, probably deserver, in his own. In entering the door, note if your new purchase lowers his hearl, as if he fearerl to strike it. If so, it has been tender at some time, and Jou may take a second look fir line sims of poll-evil.

And liow you have got to a pass wh s:e you must be at once indulgent and serere. Your horse is st:..ia so, and may well be a trifle nerrous in new quarters, with unacenstomed roices and fices, especially if he is young and spirited, and here you may be indulgent with him. His nerrousness will at least help you to díscorer his bad points, for it will be apt to lead him to a goneral display of them all, and this is why dealers olject to giving this "trial time" unless they can themselves have a hand in the manarement and showing off.

Put the liorse at once on a somewhat short allowance of cl:y folder, the dryest you have. Not for cruelty, but to see if he has any cough or other signs of disease of the throat and lungs. If, too, he was unle: the influence of stimulating food at the time he was shown you, this will most speedily bring him back to his every day condition.

Then, on the following rlays, will come the sereral experiments in riding; driving and pulling; and here all morely rerbil instruetions would be at fault. If yud ro not know how to lanmess or hanlle a horse, or how to rile or livive one, you might womy the best quarlmper in the world into all imaginable exhibitions of vice and temper. Such hints as may serve as a partial fuirle in a fiu:ther incuiry into the training and condition of your purchase, must be gathered from a careful study of the remaining chapters of this book. This is equally true concerning both faults and disenses.

If we may suppose that you 1. re liscororerl faults, defects, or 
signs of disease, which in your opinion traverse the terms of your warranty, do not hesitate for an hour; have the same duly noted by two or more credible witnesses, make a note of it all in writing, and at once lead back your rejected purchase to the stable from which you took him. Let a witness go with you, state your objections, listen to no argument or explanation, formally demand your money, get it if you can, at all events leave your horse and make the best of your way to such further legal proceedings as may be necessary under the laws of your State. If you have paid no money, so much the better, as you are then pretty safe after you have returned your horse with a statement oft he reasons as directed. By no means leep him twenty-four hours after you have made up your mind that you don't want him. Neither be persuaded to surrender your guaranty, if you have one, with the horse, as it may protect you from further annoyances that you dream not of.

And here we will close our outline of hints about the very simple business of "buying a horse." 


\section{CHAPTER SEVENTH.}

\section{SOME GE NERALA DVICE.}

Disposition, temper, courage-Deceptive appearances-English colt racingIIard usage of young horses-Decrease of value--Increase of valueProblems for horse-owners.

Horses are after all a great deal like men, and it will not do to put too much trust in externals. Disposition, pluck, fire, that inscrutable something in man and beast which the old Romans called virtus, and which is more than beauty and more than muscle or bone, must be taken into the account. Some of the best horses in the world's history hare deceived the best judges of their day, and we might multiply examples, but we prefer only to draw one moral:- "When you get a good horse, keep him, keep him!" If you lave tried him in various ways and found that he is about what you want, let no temptations of flashy "trades" or "boot" lead you to part with that most excellent friend and profitable servant, a thoroughly good horse.

The remainder of this book will be devoted to rarious treatises on the best way of using him in work, housing him, feeding him, and treating his illnesses, so far as general instructions can safely go.

It is matter for general congratulation in America that no such stupid and cruel system as the English races has yet sapped the vitality of our hest breeds, but we need to be on our guard lest avarice shall perform an almost equally evil office for us. The English colt is made to train for races and run them at two and three years old, and the consequence is, according to no less an authority than "Stonehenge," that during the past ten years the De:by itself has five times been won by unsound colts, whose trainers were immediately afterwards compelled to put them nut "If work, either from diseased feet or a break-down. Ifow large a proportion of unsound colts were found among the losers of those and other races, or among the immense and motley herd that erery 
year break down in training and never show on the course, no English trainer or writer has been found frank enough to confess, but they are going forward with their hot-house forcing system, breeding in-and-in from these diseased and ruined "winners of the Derby," \&c. Where thoy will end is none of our business, but there can be no doubt that a vast number of horses in America are put to too hard work for their age and therefore fail of ever becoming as good as they might. A horse completes his dentition at five years old, and is then said to be mature, but if his owner is a little careful and easy with him, for that year, he will be all the more apt to be sound, hardy and serviceable in his seventh, eighth and ninth years, and so on up. The average age of the horse in a state of nature, is about twenty-five years, and if he is permitted to begुin life with a decent constitution, is not foolishly broken down while a mere colt, and is afterwards treated well and wisely, there is no reason why he should not continue useful at least till he is twenty. This is especially true of mares, which are generally longer lived, for various reasons, than either stallions or geldings.

It has been common with some writers to count the annual decrease in value of a lorse, after five or six years of age, including insurance arld interest, at one-fourth of his cost price, and it may be that this is not far from right. If so, what rolumes does it not speak for the stupidity, folly, cruelty and mismanagement of American and English horse-owners! The fact is, that from five to eight years of age, a horse ought to constantly increase in actual power and usefulness, and, therefore, in real value. Perhaps there is a good time coming, even for horses.

The problems which we would suggest for the consideration of cvery human being who comes into possession of a horse, are, "How can I increase the value of this quadruped, either in use or for sale? How can I overconie such faults and defects, as he may now have, while I keep him from acquiring others? How can I make him last the longest, and perform the greatest amount of good work for myself and othets?"

In anything like horse-breeding and raising, other questions come in, and these will be duly attended to, in their proper place, but for the present we only propose to have a sharp cye out to the comfort, safety, and pecuniary well-being of those of cur readcrs, who may hammen to he ntunns of horses, purchased, or othorwise. 


\title{
CHAPTER EIGHTH.
}

\author{
STABLES AND FOOD.
}

Diul stabling in America-Stabling in the South and West-Sudden exposture -. Gity stabling-Stalls and boxes-What room a horse wants-Fresh air and ventilation-Stable floors and drainage-Light and warmtl-Dampness and its evils-Location and temperature-Bedding and feeding.

Comparatrvely speaking, having in mind the vast number of our horses, there are very few really good stables in the United States, in spite of the undeniable fact that it costs no more to build a good stable than a bad one, while nothing is more positive than that bad stabling, and its consequences, destroy more horseflesh, every year, than crnelty, disease otherwise caused, and overwork combined. In the Eastern and Northern States it is hardly comprehended, that over an area compared to which those States are but a "patch," the horse is deemed competent to take care of himself luring the winter months, and the idea of careful stabling is almost a matter of ridicule. Long residence in the South, the West, and the South-west, has made the writer hereof familiar with the abuses to which horseflesh is sulject, in those seemingly favored climates, and to lend the weight of experience to his assertion that not even in Maine are good stables, adapted to tho climaie, more necessary than in Virginia, Southern Illinois, Kentucky, Arkansas, and the new States now arising in the far interior. During a jart of the year, and in any of our climates, the changes of temperature, and the chances of severe exposure, whether to man, or beast, are of no account, but in no region within our borders, does this continue the year around. Even in the all but tropical climate of Southern Texas, the destroying "norther" will suddenly and unexpectediy swoop down upon the tender and :uprepared bipeds and quadrupeds. As a rule, while no system of stabling (for man or beast) can be too complete, or provide too carefuily for all ordinary wants, those climates which tein most to nervate lic sy jem of the horse; and unfu him to endure hardships 
of temperature, or tempest, by that very fact most clearly demand that their exceptional conditions should be most carefully guarded against. A good shelter is as indispensable in Texas as it is in Michigan.

In cities, or wherever "roum " is an object, the horse must be confined to a "stall," unless his value or the state of his health entitle him to the temporary honor of a box, but in the country generally there is little reason for restricting him to penitentiary measurement. We have seen some admirable homes for horses made, out on the prairies, out of loose $\log$ walls, and a floor kept dry by a deep ditch dug on the outside.

As not one in a thousand of our readers has any money to sink in experiments on fancy stables, even if he has obeyed all our other suggestions as to buying a horse and bringing him home, wo would now offer the following as the desirable features of a good stable, adding that the very most expensive and elaborate establishments in and around our great cities have-generally failed in obtaining them, while many a ricketty old "pole-house" on the prairie has supplied them in perfection. There should be room in which to stund up, feed, lie down, stretch out, and even turn around. Neither man nor horse should be put into a "coffin " until he is dead.

There should be plenty of air. Not an occasional blast through the door, to chill damp heels, and shock tender places generally, but an equal and easy circulation, carrying off foul smells, to which decent horses are sensitive, and otherwise giving the lungs of the imprisoned animal a chance to continue undiseased.

There should be a dry and well-drained floor, and it must be made soft and yielding, by litter or otherwise, so that the muscles of the legs may not be stiffened by standing on it, or the hips, shoulders, etc., wearied out when the horse is lying down. Eren such receired authorities as Youatt, Walsh, and McClure, and others, seem to take it for granted that the floor of a stall or box must "slope backward" in order to secure drainage and dryness, thereby insuring an unhealthy and annoying strain on the horse's hindfeet and quarters. A man who can't drain his stable without such a slope, should speedily forget all his Funkee ancestry.

The stable should be not only a shelter from sun, rain, and storm, but should be capable, in due season, of being made 
exceptionally warm, for tie oecluion, and then alone, of all the year, it may excusably be male "dark" for the time heing. As a general thing, the lighter the stable is the better for its occupants.

There is no stable on the wildest prairies, in the newest settlements, whose builder and owner cannot profit materially by paying due attention to the abore hints, and as a general thing, he can clo so practically without ardling greatly to either his trouble, or his cost. To an immense number of horse-owners, in cities especially, more room is impossible, more light is out of the question, rentilation is one of the fine arts, and a dry, clean, soft, well-belded floor is a matter of enthusiastic aspiration rather than of immediate practical attainment. We are sorry for them, but even to thom, as well as to our more fortunate country cousins, we may be able to offer a few additional hints.

Whatever your stable may be as to other points, it must absolutely not be damp. The horse comes from a dry climate, originally, and his constitution bears this special anilogy to that of his human master. Starvation itself hardly tells on him more injuriously than a damp stable. He loses his endurance and his appetite: his coat stares in all directions: his head droops and his spirits ooze ont at his shivering extremities: he loses flesh; and then come chapped heels, scratches, hide-bound, swelled legs, inflamed eyes, coughs, colds, and other evils, and, if any horse epidemic happens to be going the rounds, it is pretty sure to step in to the rescue of the victim of a damp stable.

In cities a man camnot help himself, but in the country he woull 1 do well to build his stables on a little knoll, or the sir? of a gentlo slope, that he may secure that good drainage which is the sime que non of a good stable. As to which way the stable is to look, that, must be governed by the prevailing winds on that particular spot, bearing in mind that no two are alike. Generally speaking, a southerly front is best, but what may be good on your hillside is by no means sure to be the thine for your neighbor.

There is a natural diffenlly in keeping down the temperature of large stables, where many horses are kept under the same ronf, but much may be done by means of slight board partitions and separate ventilation. Not more tian four horses should be kept really "together," except in winter, as their animal heat will be sure to produce an unfavorable excess. 
Even in the country a "box" or large, loose stall, can harlly bo provided for more than two or three favorite animals, but its advantages are obvious, and in all training or racing stables such boxes are kept at least for the more valuable animals, or for those who are sick. The horse, however, is a gregarious and sociable creature, and he will do better if he can be kept within speaking distance of one or more of his kind. This peculiarity differs with different individuals, but some horses will eren lose flesh if confined too much by themselves. Whether in stall, or in box, there should be nothing left around in the way of nails, spikes, corners, or other protuberances, upon which the horse will be in langer of injuring himself in any of his movements. If this is provided for there are very few reasons, bearing only on particular cases, why the animal should not be left entirely loose, unhampered, unhaltered, unconfined except by his four smooth walls.

A "box" should be at least nine feet to twelve feet wide, and half as long again, while six feet wide will do very well for a mere stall. As to the materials to be employed, these are necessarily governed by the place and circumstances, as well as by the pocket of the builder, but the real essentials of health and comfort can be secured almost as well by the poor man as the rich, except in cities. If the loft or space abore the stall is used for storage of any kind of grain or fodder, care should be taken to have the floor tight that no dust may sift down from above to annoy the eyes, nostrils, or lungs of the horse, and that the exhalations from below may not come up to taint the food. This end cannot be secured in feeding with the old-fashioned "manger," contriver to accornmolnte laziness, and secure the greatest amount of waste with the $\mathrm{r}$ !most possible inconvenience to the animal. In a state of nature the horse always stoops his hear for his foorl, aud the same plan should he provided for in his domesticated life. It may cause a ve:y l'ttle mo:e trouble, but it will pay in rarious way.

In the rural districts of this country, and especially in the West, "Y.: te:" costs little or nothing except a little care and foresiglit, aid even wlere it is comparatively scarce it is one of those things in which it is very easy to be "penny wise," as a dry, clean, and plentiful bed is of prime.importance to the health and working condition of all horses.

Whether box or stall, or whether he is to be left loose therein, 


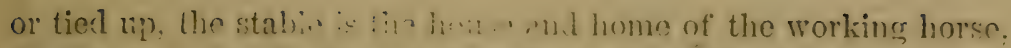
during, at least, the larger lout of his liti', and its arrangements and provisions are of such impoitane that we have spelien of them in the first place. Some animals, of exceptionally tough organizations, will seem to do well in almost any sort of a hovel, but with nine out of ten, good condition is impossible for any length of time without proper attention to the leading points which we have mentioned.

And now, if the shelter is attended to, we may proceed to that. much rexed, and most important question, the food and divine of the horse.

The great mass of controrersy on this subject may be promptiy set aside as being of only local application, and with it, as a mattei of course, almost all of the singularly inapplicable, and often incomprehensible stuff, which so many so-called "American" books on the horse, reprint from English farriers. That which may be very good in England may be very bad, or quite impossible, here; and such is the ail but infinite variety of our soil, climate, and productions, that a set of rules on sprcific feeding, cesigned for general use, would be simply laughable if they were not also likely to be generally clestructive.

It is to be regretted that, over so large a part of the United States, farmers and others who ought to know better, and for the greater part do know better, permit themselves to be so lavish atid careless in the use of so heating an article of diet as Indian corn. to the exclusion of safer, and really cheaper foud-chenper to rrow, and cheaper to gather-but the adoption of a more natural and healthful diet will be slow. We very much wish that this treatise could help in producing such a result. Corn is grool, but its misuse yearly ruins many thousands of horses, to our certain knowledge.

In the first place, then, a horse is not a camel, with a wlule row of stomachs, calculated to hold provision against a lone s.en. Rwatively to his size, and the work required of him, the siomach of the horse is small, and it is sure to be empry in at little more than four hours from the time he filled it $A$ s a consequence of this, if the animal is kept at work, or is deprived of food for a much longer period than this, he is first attackel by a roracious hunger which would lead him to eat ton mush, whd hurt himse!f 
if he had a chance, and this in turn, with further delay, is iollowerl by lassitude and exhaustion. The whole frame feels the evil effect, and any particular part is more liable to "strain," if at work, but the stomach is particularly affected, and the appetite is often so destroyed, temporarily, that the most tempting food is rejected. It follows from this that the horse should be fed not only regularly but frequently. A man can go much longer without food than a horse, and with much less danger of bad consequences. Still, even this must necessarily be at the mercy of circumstances, and we can only give the general rule of "morning, noon and night;" and oftener if the work is hard, or the speed demandecl, great.

Thought should next be given to the peculiar temperament, size, health and habits of the individual horse to be fed. There is here an infinite variety, and a great deal depends upon education. A horse will accustom and adapt himself to almost anything, except starvation, if he can take his time to it, but due allowance must be made for the force of continued habit, and for the consequenl condition of the system. Too violent changes are never advisable, even when the animal is off his work, much less when he is busy.

The next thing to be thought of, while never losing sight of the others, is the kind and amount of work that is being exacted, ant for which the horse must prepare himself. The same kind of foor will positively not provide for all the requirements of the frame of the working horse; he needs a variety as much as a man cloes, anct he cannot be kept permanently useful without it. How often has erery horseman seen his four-footed friend turn from the best of grain, corn or oats, as it happened, to nibble greedily at even inferior hay, while on the other hand all men know that the horse kept long on hay alone becomes exceedingly hungry for grain, no matter how abundant his other food. Too great a sameness is a very general fault in our methods of feeding, and we suffer tho consequences in many ways.

These is very little danger that a horse will become too fat if steadily worked, and his food should at all times be so régulated as to keep down any such dangerous tendency, but, except in some few breeds, or exceptional cases, it is a mistake to suppose that "good condition" implies an approach to the "living skeleton " style of development. "Not fat but full" is a good proverb 
for a working horse, whether uncler the saddle or between the shafts. He needs a fair supply of both hay and grain, and theso also may be profitably varied from time to time, with such arlditions or changes in the way of cut roots, cooked stuff or green food, as circumstances may suggest or permit.

The only seasoning a horse cares for is a little salt, and he will eat less of this if it is always where he can get at it than if supplied to him at long intervals. It may be sprinkled on his hay, which is the most wasteful method; it may be put in his water, not to cxceed an ounce a day; or it may be fed at intervals in the shape of fine salt, according to judgment. A better way than either is not often practicable in this country: it is to put a largo lump of rock salt in the manger, and let the horse help himself by licking it. Some will use more than other's, but the most "salthungry "will eat less than half a pound a month.

A horse will oftener liurt himself with water than with food, because he can get down a larger quantity in a shorter time. In a state of nature it may be that he can take care of himself, though the collections of skeletons around Western pools and springs would argue the contrary, but in his domesticated condition the horse requires to have his appetite for "drink" regulated by human reason and experience. With water, as with food, the supply needs to be regular and frerguent rather than large, and the oftener a horse is watered the less he will really drink in the agrregate. Still, some horses need more water than others, and the same horse will vary rery much in his requirements at different times, and under different circumstances. Just before hard and heating work, or just at the close of it, only a norlerato supply should be given, but at night, after the animal is thoroughly cool, he ought to have just as much as he cares for, and the amount he swallows may be noted as indicating his internal condition. Fever of any sort will have the same thirsty effect on a horse as on a man. If a horse is being changed from dry food to green, it will be well to diminish his water at first, as a full supply will be apt to bring on a fit of colic.

As to quality, the water given to horses should be the very hest that can be obtained in the place where you are, and, if it is mixed with vegetable or earthy matter, it should be filtered or settled if possible. By no means gire cold spring water to a horee warm 
from his work, unless you have a spite against him, as it is apt to be an exceedingly dangerous experiment. Let it stand awhile, or even take the chill off with a dash of hot water. Of course it should not be warm to the touch or taste, all that is necessary is to prevent a shock.

In some "fancy stables," nowadays, arrangements are made for a continual supply of water in each stall or box. There can be no objection to this plan so long as the water trougis are kept very clean, and no horses are licpt. If the latter is intended or attempted, tire animals should be cool, and not at all thirsty when they are led in. 


\section{CHAPTER ' NINTH.}

\section{STABLING AND GROOMING.}

Grooming and cleanliness-Perspiration and scurf-Rubbing and brushingAn.l, wet legs and washing-Iloots and heels-Cooling down-Shedding tl:- coat-The fetlocks-The hoof in the stable-Preparation for shoeingTiet Hoors and "Thrush"-Examining the shoes-Exereise.

Oxce fairly bought, brought home, and properly stabled, the horse lias passed a very serious ordeal, but other and most important duties at once press themselves upon the humane and economical owner. Frequent bathing, cleanliness, goes further with even a mau than one man in a hundred knows enough to acknowledge, but the careful grooming which answers the same purpose for a horse is of even greater relative importance. A well "dressed," well groomed horse, will go further in work, on less food, in better health, with less liability to damage, and come out of it in better condition, by all odds, than his carelessly treated neighbor. In fact, more than half of the discases, and the worst results of more than half of the accidents, including overwork, bad judgnent, changes in the weather, careless feeding, and all that, can be robbed of their most pernicious effects by judicious painstaking in the stable. This point is to bo urged the more earnestly here, because bad and careless grooming is a prevailing vice among American horse owners, especially the farmers, and in the West and South we have been personally cognizant of a most lamentable waste of horseflesh in this way. Good stable management includes a multitude of separate items, some of which have been already referred to, incidentally, and more that camnot be brought within the scope of this chapter, but we must positively insist on certain points.

The cases are certainly exceptional in which the stable, however poor it may be otherwise, cannot be well drained, dry and clean, when the liorse is led into it, and there are not many places in America where the absence of good litter does not imply laziness and shiftlessness rather than any kind of economy. If by any ac:- 
cident it does mean economy, it is of the meanest and most short sighted kind, assuredly defeating itself in more ways than one.

If then the stable is made dry and clean, so should the horse be. His skin must be kept pure. In sweating he exudes a matter which at once dries and forms scurf, and this a mechanical obstruction to the free action of the pores of the skin, and even if he has not been sweated so as to make it visible to the eye, his. " insensible perspiration" has certainly rendered brushing and rubbing desirable. It is not a mere surface polishing that will answer all the ends required; the effect is to be produced not upon the hair, but upon the cuticle itself.

The wild horse, or the tame one, when he is out at grass, may have a rough-looking coat, but the very winds to which he is exposed do his grooming. When he is kept in the stable all the time he is not at work, artificial means must take the place of natural ones. The action of the skin, its secretions of the necessary oily matters, the delicate machinery of perspiration, must be kept in healthy activity, or nature will arenge her'self speedily by colds, coughs, and other clisurders. Any one will be willing to aclmit that a horse needs especial care and vigorous grooming when he comes in wet, muddy, or dusty either, from long and wearisome exposure; but fewer take the trouble to think that the horse who has done no work, has not even had exercise enough to stretch his legs, needs a good rubbing quite as much, if only by way of exercise.

If you are to be your own groom-and, even if you do it by proxy, you had better gire the matter some personal attention,begin by taking note if your horse has a thin, tender, delicate hide, or whether his epidermis is of the rhinoceros kind. The latter will need less manual dexterity but not less vigorous rubbing. Upon this too will greatly depend the nature and use of your currycomb and brush, and here a trifle of humanity and good judgment is to be exercised. Do not run a "hard-harrow" over" a delicate and shrinking $s$ kin, and, on the other-hand, be sure yau get at the roots of a coarse, thick coat of untrimmed hair.

Begin at the head, with your brush in one hand and your currycomb in the other; take particular care of the ears, where dust is apt to gather; go down the neck, shoulders, bosom, legs, and so on back, with the brush only, and then repeat on the other side. 
Complete by going all orer with a wisp of clean straw, a littlo damp. In spring and fall, when the coat is changing, only rub with a cloth or some straw, if you want your horse to look well afterwards. Do not misunderstand the use of your currycomb; it is for mud, obstinate bits of dirt, or an outrageously neglected coat; otherwise it is worse than useless, as your shrinking horse will plainly tell you. A damp sponge should be, used for the. horse's cyes, nostrils, and anus, and these should be dressed out with a light and rapid hand. The legs and feet require especial atténtion. No matter how wet they are, they should be washed clean, and all foreign matters picked out of the hoof. The heels should be left clean and dry, so that draughts of cold air may not superinduce chapping or scratches. The more delicate points of grooming are only required in those stables whose wealthy owners are able to secure the services of trained professionals, but even these gentlemen will lose nothing by an hour among their quadruperls to see if all is done that is professed to be.

When a horse is going out to his work, give him a quick rubbing down with a wisp of straw. Not only will he start off better looking, but, what is of more importance, in better temper and with a glow on him which better fits him for the possible changes of temperature.

Grooming when a horse comes in from work, or any kind of violent exercise, depends a good deal on his external condition, but it should be done, if at all possible, before he feeds. The reason of this is, not only will ho take his feed better, but all possibility of danger to him from eating or drinking will be over by the time you have done with him. If he is dry and clean, and not at all warm, a rub with a wisp of straw for a few minutes is all that is required.

If it is warm weather, and he is sweating profusely, lead the horse about gently, till he is quite cool. If he had a saddle on when he came in, let it stay on till he is cool, or he may have a stiff back next day. If it is cold weather, and he is warm, take him under shelter at once, and rub him dry with a cloth. By no means let the skin remain full of dry sweat, as this clogging of the pores practically defeats all their purposes. Waihing, even with soap and water, is as good for a horse as for a inan, lut care 
should be taken with the one precisely as with the other, that the skin is thoroughly dry and bright when the work is done.

If, as very often happens, a horse comes in very muddy, it is a cruel sort of laziness to let him stind and dry with it all on, trusting to brooms and comb to tear it all out after it has thoroughly hardened. The black soil of the prairies sometimes malies a particularly hard and tarry cake if allowed to stiffen in the hair. The really easiest and cheapest way is to give the animal at once, a thorough washing and drying. It may be disagrceable, but it will pay. In fact, hardly anything else in the management of the horse will really pay better than simple cleanliness.

If a horse is merely well wetted by rain, simply rub him dry, as if you had washed him yourself, and make sure that his feet are all right and not stopned with mud or gravel.

If a horse is brought in completely used up, even if there is danger that he has been injuriously or fatally over-driven, the first, best and only thing to do is to cleanse him and groom him thor oughly. It is his best chance and he will enjoy it immensely. Rub every joint in his body. Rub every inch on his skin. Rub his ears gently. Have some gruel made, if he is really bally off, and rub him while they are making the gruel. If he is injuired his ear's will show it by, their low temperature, and he will be especially pleased to have them rubbed.

"Grooming" may be described, somerwhat imperfectly, as the care of the horse's skin and "coat," and it includes some other cares besides cleanliness, important as that is: among these in some stabless are "clipping and singeing," in neither of which, we hope the rea!lers of this treatise will indulge. Very surely they will not, except they happen to be proprietors of strictly "fancy stables," caring more for externals than anything else. Still there is something more to be said about the coat of the horse. He so accommodates himself to rarieties of climate and even to the more minute variations in the care taken of him, that purely general statements concerning his shedding or "moulting " would necessarily be true only within rery narrow limits. Any description, therefore, macle and adapted to one locality, may be adjusted, with a mere trifle of experience or inquiry, to any other.

The coat of the horse, except in extremely warm countries, is changed twice a year. The lon hair of winter comes off in April 
or May, according to the weather or the warmth of the stable in which the horse is kept. Work, especially such as to produce perspiration, hastens the shedding. The hair on the legs is slower by some weeks, in coming off, perhapss because these limlss are more exposed. Even here it can be hurried a good deal by grooming. Different breeds of horses, and different animals in the same breed, show very marked variations in the nature of their summer and winter coat, and with some the change is rery slight. "'he difference is always less perceptible among blint horses, odd as that nay seem.

Along in October, earlier or later according to climate and the character of the season, the summer coat begins to come away and the "winter coat" begins to make its appearance. The latter will often continue growing until midwinter, and its hairs aro longer, coarser and closer than those they have displaced. On the legs the change is more distinctly manifest than on the body, presenting what is called a "feathered" appearance. In the case of race horses, or perhaps some others in exceptional situations, there may arise a necessity for artificially trimming and reducing this provision of nature, but in ninety-nine cases out of a hundred it will be wiser to let it alone and put your scissors to some other use. We are aware that some very respectable authorities have written differently, but we bear in mind that they were not writing fo: American readers or the climate of the United States, while ive are.

Some stupid grooms, even some writers on farriery, will tell you to clip or singe the long, bristly hairs about the eyes, nostrils and cars, but be very sure that you do not do it, for they are in each case feclers attached to nerves of sensation, and are of use to the animal in warning lim of the nearness of solid substances when the is groping in the dark. Any other unsightly growth about the head or neck may be freely trimmed away.

The fetlocks, if any care is to be laken of the horse's teet, may be trimmeil reasonably close, unless he is to be worked in the plough, or otherwise, in soft and treacherous ground. If this latter is the case, by no means cut the fetlock close, as it is a natural protection against sudden blows, irritating friction and other exposure, and the foct will be all the hester for it. Neither the

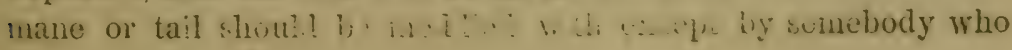


knows how to cut them, that is, an experienced groom. If a man. is bent on trying his own hand, however, let him be sure that his scissors or knife are strong and sharp, and that his own hand is firm and steady, for horsehair is tough cutting.

A very important part of stable duty, and one which is rery commonly neglected, is the proper care and supervision of the horse's feet. Constant attention is required, but if it is only made a matter of habit it need not be irksome or unpleasant. That which is a "matter of course" is rarely a matter of toil.

It is a great pity that so many of our blacksmiths are so ignorant of their business, but a great deal may be done, in the stable itself, to counteract the results of their folly. For most points we nust refer the rearler to the chapter on "shoeing," confining ourselres just now strictly to our " text."

Earth floors, if dry, well cleaned and drained, would be the best for a stable, but as they would involve considerable care and labor, some harder material, almost unirersally hard wood, is substituted for nature's provision for the wild horse. Now, wood is a bad conductor of heat, and the shod hoofs feel nothing cool or yielding under them. So, if neglected, they become dry, hard and brittle liable to crack in work, or to chip off in shoeing, or to "batter" badly on stony roads or pavements. To prevent this, a good horse-keeper will give the feet a "stopping," every now and then, say once a week; that is, he will talie a bit of shingle, and paste the hollow of the lroof full of mud and cowdung mixed, and leavo it there all night. If that don't succeed, try the dung alone, or lut a little salt in your mixture. The last will ncver fail, but it must not be tried except in cases of extreme dryness, as it is too strong for safety on any ordinary hoof. Eren if the horse's feet do not show any signs of dryness, always gire them a good "stopping" the night before he is to be shod, so that the hoof may be tough and yielding, inslead of hard and brittle, in the hands of the farrier.

In carelessly kept or badly located stables, like too many that we now recall, disgraces to their lazy and reckless owners, the hurse's feet are kept too wet, and the soft part of the sole of the font becomes diseased, the onter coating of the frog becomes decomposed, discharges filthy smelling matter, the frog wastes away, the protection of the sensitive organs beneath is gone, and 
this is what is called a "thrush." There are other ninds of thrush, brought on in other ways, but this is bacl enough. It is not always hard to curc, but prevention is better. This can he secured by having dry litter for the animal to stand on, and by keeping the frog of the foot scraped clean from foreign or dead matter. Leave any cutting to the farrier, but be sure the frog is in good condition:

One of the stable duties is to take a good look at the shoes whenever a horse goes out or comes in, to see if they are firm, and none of the clenches of the nails are raised. Of course a horse is never to be worked with a loosened shoe, as he runs all sorts of risks, and so does his rider or driver.

Never keep a horse long in the stable without good exercise: he cannot keep in good health and condition, nor will he work with any safety to himself or others, on being suddenly released from his undue confinement.

As to the temperature of the stable there has been a good deal moro controversy than sound thinking. It is a matter which cannot be altogether controlled, and it is best that it should be permitted to vary, steadily, with the season. This will take place in the process of ventilation, while many precautions can be taken against changes that would be too sudilen or excessive. With good ventilation the stable can always be kept warmer in winter, and cooler in the greatest heats of summer, than the outside air, and this is what is required by the constitution of the horse. At all events, attend to the rentilation first and the temperature afterwards. If it is too cold, do not shut out all the air, but pile more clothing upon the horse.

Nearly all of our so-called "American" books on horses, being merely reprints, with perhaps a few slight and trashy additions, of English works, are disfigured with prolonged and "snobby" chapters describing the mauagement of English racingr and. hming stables, and the manner in which European "gentlenen" keep their fancy stock, all of which is simply pernicious in a book intended for use in this country, nor do we propose to reliash for our farmers' boys and busiuess men, these rery remarkable accounts of how the noble for hunters and race gamislers manage their high-blooded, delicate, pampered and, very generally, unsound and evil-tempered quadrupeds. 
With "stable vices," and the way to cure them, as well as the trea:ment of accidents, we will deal in another place, cosing this chapter with the general remark that so long as humanity; thoughtfulness and good sense are allowed to kick laziness, brutality and prejudice clean out of the stable, the horse population will have a fair chance for long, useful and comfortable lives. 


\section{CHAPTER TENTH.}

\section{PASIURE IIINIS.}

Soundness of hay or grain-Gireen fool and soiling-Changes of food-Brud weather and extrat care- Sheler in the rawture lot-Watering in pastume - Flies in the tield-Taking up from pasture.

Tire fool of the horse in different sections of the country, and iil the all but infinite rariety of circumstances, in which he and his owners find themselves, must necessarily vary rery willely, an:i with judicious managenent, the antmal, of whatever breed, will nrlapt himself marrellously to all changes of locality of of seasc'n. We have aliealy given some lints, and it ought to be uniecessa:? to aclit that, so far as is possible, each and erery article should lic counk and good of its kind. Mouldy or mowburnt hay is so much poison, and so is lieated or mouldy grain. If corn or other frain is dusty or otherwise unc?ean, it is certainly a matter of but little trouble to winnow or sitt it, and it is well worth while, as sucli foorl, if it does not originate discases: is sure to foster or argravate many affections of the eyes, nostrils, throat, lungs and bowels.

The great majority of our horses, learing out those funally doomed to be used un in the relentless toil of our great citics; have at some time of the year a chance for a little green food, either by soiling or by being turned out to grass, and this is an excellent thing, but it would be a by no means useless curiosity to inquire how many animals are badly damagred, or even destroyed, every year, by ignorance or carelessness in the way in which they are brought to or from their grass.

If a horse is to be turned out to grass in the spring, or for amy cause at any time during the summer, care must be taken thiat the change from dry food and grain, with larro work and ciose? confinement, to perfect liberty and green food in abuntancon, should not be too sudden.

Take some days to it. Cut down the allowanos of wain. Brises

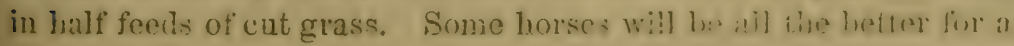


dose of physic. At first, especially in the spring, or if the weather is bad, have your horse up to the stable at night and give lim a good grooming. Don't neglect this latter, anyhow, if there has been a cold and pelting storm, such as we are generaily quite liable to. You may refuire your horse's services at any time, and it is well to keep him somewhat under your hand:

Be sure that your pasture lias some sort of shelter from extremes of heat or cold, of wind and rain. Let it be something better than a thin-leafed and shadeless tree, or the lee side of a mullein stalk or a rail fence. A close thicket of any kind, such as hazel bushes, sumach, canebrake, a rucle shed, a mere shanty of poles and boughs, any sort of make-shift, if you cannot afford better, will be of real ralue before the season is orer, and it may bapper to save you your horse. A bald, bleak, storm-swept, sun-beaten patch of hillsicle or of prairie, however good the grass or wide the limits, is no placo to turn a good horse out into, if you expect to get him back in working trim.

If there is no ruming brook in the pasture, nor cool and sharly pool of clear water, remember that there is as much of a necessity for abundant and regular watering as ever in the stable. The horse will drink somewhat less on green food than on dry, as a matter of course, but grass is no substitute for water. In localities where flies and other insects are severely troublesome, a coarse net of some kind will often be found an excellent inrestment. We knew an ohl fellow ouce, in the West, who even went so far as to put nets on his work oxen. He mas well laughed at, but while the cattle of his neighbors kicked themseives thin and weak, his own remained in good trim ail summer, in spite of even green head flics.

In taking a horse back from the pasture to the stable precautions must alco be taken to accustom him gradually to the change of diet, whaterer it may be. He will be almost sure to fret and worry at first, and his bowels require a good deal of humoring. Fe should by no means be put at once to his full allowance of work, and extra care should be taken in all the items of stable manacrement. A few days of attention and his elastic constitution will nnce more settle fairly down to the ordinary routine of stable life and labor. 


\section{CHAPTER ELEVENTH.}

\section{THE HORSE'S FOOT.}

Careless shoeing-Feet of wild horses-Shoeing in ancient time-Army fit riery-Nemess ties for protection-- Uses of the shoe-Methods of accuiring information Parts of the hosf and their uses-Waste and injuryMachine-snade shoes.

BEFOrE attempting to treat of the management of the horse in worlt of any kind; there is one subject to be attended to uponi which it would be difficult to say too much, or to say it tor minucly, and yet it is one to which, especially in the rural districts of the North, in the South and in the prairie country, ani inmense deal of the most culpable careiessness is prevalent. We allude to Smorisg.

It is a common superstition that the horse gets along admirably without shoes in a state of nature, and that his unprotected feet retain their liealth and perfection, although unaided by the care of the groom, or the science of the farrier. This is an absurd error, as the writer has ascertained from careful cxamination of the hoof: of many wild horses. On soft ground, where they are not suficiently worn, the hoofs of the wild horse grow too long, thourgh this is apt to be merely a "summer complaint," rectified when the gromed is hardened, and greater scarcity of foor compels more use of the feet On the rourh and flinty plains, orer which drores: of Indian ponies and mustangs are frecuneitly compelled to joun:ney at a good pace, their feet get sore and batterel, just as i! there was nothing "will" about them. Like causes prelue like effects everywhere, and neither men nor animals live as long, o: multiply as fast in what is absurdly called a "state of nature" as when they are decently domesticated or civilized.

Perliaps any other part of the horse would get along hetter without care and superpision than his fert: and for numy acres men hate attempted, in rarious ways, to smiry)ly the needful attention. From the bufialo-hide "moccasins" of the fimes and Comanches. 
only use. on special occasions, to the patent india-rubber and steer appliances of the Eastern States and Europe, innumerable are the inventions, and almost as innumerable the imperfections and failures.

With tuo many there exists only the simple idea, a mattor of labit, more than of thought, that the horse ought to wear shoes, without ever giving any especial attention to the shape or conclition of the particular feet in question, or to the lind or degree of use to be required of them.

"The shoes are to protect the feet."

of course they are, but how and in what manner?

And here comes in a species of "conflict of ages." Time was wion even the cavalry of great armies went unshod, and not unfrequently were reported at headquarters as utterly useless, on account of the condition of the feet of the horses from bad roads and over-travelling. In modern times the same amount of destruction is accomplished more gradually and more in detail, and the crganized good sense, and the enforced education of army farriers, ailed by surigical science, has secured for the cavalry horses of the world an incomarably better average of skillful shoeing than falls to the lot of their lardworked brethren in civil life. A rast amount of worse than useless inrentire genius and would-be instruction has bcen wasted in contriring empirical systems by which all the feet of all the horses could be accommodated and adjusted to some given rule or formula, as if anything imaginable could be made to talie the place of indiridual knowledge, care, intelligence and patience.

A rery good rule to begin with in attempting any improvement in this cirection, as in all others, is to "forget at once everything that you do not thoroughly know."

The horse's foot is to be protected, certainly, and from what? Let us see.

With only his own weight to carry, and that is a good deal, the feet of any animal are suljected to a degree of wear and pounding which is to be measured not cnly by the nature of the ground on which he is to travel, but by the rapidity of his motion, the peculiarilies of his pace, and the innumerable circumstances which govern the condition of his feet themsolves: When he is made a beast of burden or of draught, and nature's loarl is artificially 
increased, the wear and tear is multiplied, am the science of man is necessarily called in to provide as well as may be for the waste which the uses of civilization have occasioned.

Duubtless the first aim of the carly furriems was to prevent tile to: rapicl waste of the hoof, but a mere iron sole, while it weans away less slowly than the horn, communicates every shock and blow with rigid firmness to the complicated and delicate stricture above it, and heuce arose appliances, more or less effective, for the support of the yielding hoof, to prevent its spreading or cracking, to give it a firmer hold on hard or slippery ground, and to place its more sensitive and easily injured parts at a safer distance from blows and possible harm.

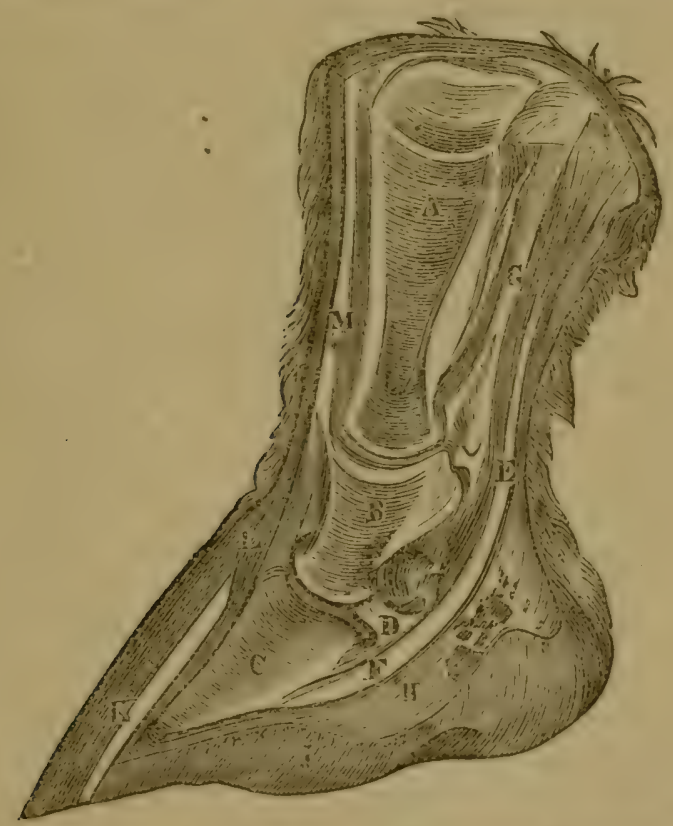

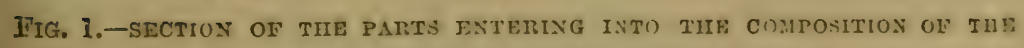
FOOT AND THE FETLOCB AND FASTLIR-JOINTS.

\section{$A$
$I$
$C$
$I$}


Thus much attained, or thought to be attained, and for ages the amount of further improvement has been small indeed, so far as the immense majority of cases is concerned, and we may now settle down to the belief that the only perceptible gain will be made in diffusing a more general spirit of inquiry and independence among horse-keepers and owners, with an equally general disposition to rebel against laziness, quaclery and traditional prejudices on the part of the farriers.

With that end in view, and on behalf of our much abused quadruped friend and servant, we invite our readeis to a carefil study of the anatomy of the horse's foot. The diagrams which we present will give a very fair basis for intelligent inquiry, but hardly any number of "plates" will enable the student to dispense with living subjects It will be very well to secure a knowledge of the technical names of the several parts of the machine, but that is not enough: who, nowadays, would trust his own body to the knife of a surgeon whose only lnowledge camo from books, however theoretically excellent, without the truer and deeper schooling of the dissectiner room?

Therefore, after learning what you can from our diagrams, lay down your book for awhile, and betake yourself to the study of living subjects. Your obserrations will consume little time and no money. Look sharply at the feet of every horse you come across, healthy or unhealthy: note their shape, if round or oval, and whether they are bright or dull; smooth, even and perfect, or rough, corrugated or battered. Get a clear conception of what a healthy foot should be, and then note the variations from that outline towards flatness, uprightness, clamage or otherwise, for all these variations require corresponding changes in the purpose and design of the shoe which is required in each particular case.

So much for the outside, if you have used your cyes well, but that is only a grood beginning. Now get a specimen foot from sonve dead subject,-no difficult thing to do, when so many poor brutes get through with their sorrows every day all about you. Takse a saw and divide your specimen down through the middle, from toe to lel. Not a very pleasant job, but it will pay splendidly in all your after management of horses. Note carefully the position of all the parts, and their relative bearing upon one arother. If the foot is a well-shaped and healthy one, you will 
gain one kind of information: if you detect disease and mal. formation, that also may be male exceclingly instructive.

If you have completed your stuly with respectable care you hase ilone more than ninety-nine "firriers" out of a liumdrerl, and know practically more than they do concerning the wonderful orran in whose torture anil destruction they cmploy their misspent lives. At all eronts, you are in a state of mincl to acruire useful information from this and other books, to correct misiakes, it may be, and to reject crochets and fallacies, such as ail writers on the horse are sure to have, thongh, of course, none wi!l acknowientere it. We will not, for instance.

Such an examination and stucly as we hare advised, will convince the student that the horse's foot is a rery admiral,le ancl wonderful machine, calculated to perform any reasonable auminint. of work if it is only kept in order, and also that its rery perfeciju: and complex arrangement make it by no means difficult to injue. It will be found that the outside line of the sole of the foot would not vary much from a circle, in a sound and well-shaped fort, if continued around, but a little fuller on the outside quanter: Noting particularly this outside crust, most horsemen will tell him that it will be softer and less durable if of a light color than if dark, - a very ancient superstition which has led to the sale of many excellent horses at less than they were worth. The hout should be bright and smooth, as these are indications of licalth and good usage, and they should be kept so, but as for color, except as a matter of taste, it does not matter, so long as sky-blue and bottle-green rlo not become too commou.

The sole should be concare, and not too dry and hard, and it should be remembered that the crust, of which the iron shoe is a sort of continuation, is intenderl as a protection for this as well as the unseen parts of the foot. Concerning this we can harlly do better than to guote from that ancient and eminent authority; "Youatt on the Horse," as follows:

"The crust, or wall, is that portion which is seen when the foot is placed on the ground, and reaches from the termination of the hair to the ground. It is deepest in front, where it is called the toc, shallower at the sides, which are denominated the quarters; and of least extent behind, where it is termed the heel. It is placerl flat on the ground, but ascends obliquely backward, and fuo:- 
sesses different degrees of obliquity in different feet. In a sound hoof, the proper degree of slanting is calculated at forty-five degrees, or the fourth part of a semicircle. When it is more oblique, or the crust is said to have "fallen in," it indicates unclue fiatness of the sole, or, if the obliquity be very much increased pumiced, or convex sole; if it be more upright than the angle we have mentioned, it shows a contracted foot, and a sole too concave; so that there is no necessity to take up the foot in order to ascertain either of these states of it. It is also of importance to observe whether the depth of the crust appears rapidly or slowly to decrease from the front to the heel. If the decrease be little, and eren at the heel the crust is high and deep, it indicates a foot liable to contraction, and sand-crack, and thrush and inflammation, and the pastern is upright, and the paces of the horse are not pleasarit. If the crust diminish rapidly in depth, and the heels are low, this is accompanied by too grent slanting of the pastern, and disposition to sprain of the back sinew ; the foot itself is liable to be weak anr flat and bruised, and there is likewise more tendency to that frequent but obscure lameness, termed the " navicular-joint disease." The foot has spread out too much at the side, instead of growing - urward, and therefore it is too much exposed.

"The crust in front is rather more than a half an inch in thickness, and becomes gradually thimner towards the quarters and heels. If, therefore, there be but half an inch for vail-hold at the toe, ard not so much at the quarters, we need not wonder if horses are occasionally wounded in shoeing; and especially when some of them are so unmanageable while undergoing that process.

"While the crust gets thinner towards both quarters, it is thinner at the inner quarter than it is at the outer, because more weight is thrown upon it than the outer. It is more under the horse : it is under the inner splint-bone on which so much more of the weight rests than on the outer, and, being thinner, it is able to expand more; its elasticity is called more into play, and concussion and injury are avoided. When the expansion of the quartors is prevented by their being nailed to an umbending shoe, the inner quarter suffers most. Corns are oftenest found there; contraction begins there; sand-crack is seaterl there. Nature meant that this should be the most yielding part, in order to olviate concussion, because on it the weight was principally thrown, and thereforn 
when its power of yieldiug is taken away, it must be the first to suffer.

" $A$ carefil ciberver will likewise perceive that the inner quarter" is a little higher than the outer. While it is thin to yield to the shock, its increased surface gives it sufficient strength.

"On account of its thinness, and the additional weight which it bears, the imner heel wears away quicker than the outer; a circumstance that should never be forgotten by the smith. IIis object is to give a plain and level bearing to the whole of the crust. I'o accomplish this, it will be often scarcely neces:ary to remore anything from the inner heel, for it is already removed by the wear of the foot. If he forcets this, as he too often seems to do, and takes off with his knife or his buitress an equal portion all round, he leares the inner and weaker quarter lower than the outer; he throws an uneven bearing upon it; and prorluces corns and sandcracks and splints, which a little care and common sense miglit lave aroided. The crust does not vary much in thickness, until near the top, at the coronct, or union of the horn of the foot with the skin of the pasterns where it rapidily gets thin. It is in a manner scooped and hollowed out. It likewise changes its color and its consistence, and seems almost like a continuation of the slin, but easily separable from it by maceration, or disease. This thin part is called the coronary ring, and it receives within it, or covers,

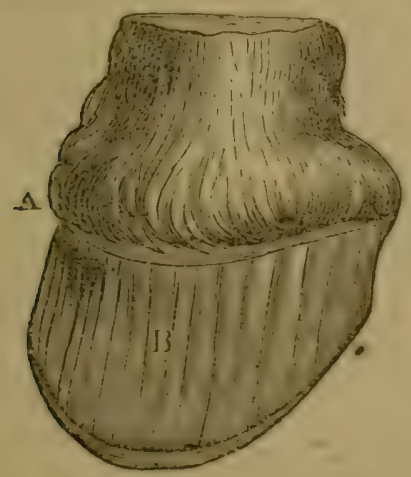

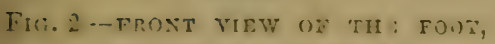
WITI THE HOOF RTMOVED.
A. Curonary substance.

B. laminx.

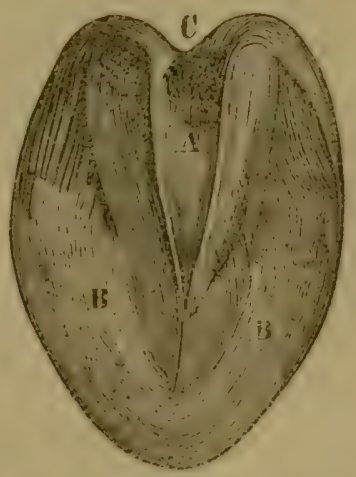

IIG. 3.-TIIV UNDER SORFACE OF THE FOOT.

A. Cleft of trog.

B. B. Sole.

C. Cleft between heels. 
a thickened and bulbous prolongation, of the skin, called the coronary ligament. This requires a better name, for it has not a portion of ligamentous structure in it. This prolongation of the skin is thickly supplied with blood-ressels. It is aimost a mesh of bloodvessels connected together by fibrous texture, and many of these resscls are employed in secreting or forming the crust or wall of the foot. Nature has enabled the sensible lamina of the coffinbone to secrete some horn, in order to afford an immediate deferice i)r itself when the crust is wounded or taken away. Of this we have proof, when in sand-crack, or quittor, we are compelled to remove a portion of the crust. A pellicle of ho:n, or of firm hard substance resembling it, soon corers the wound; but the crust is principally formed from this coronary ligament. Herce it is that in sandcrack, quittor, and other diseases, in which strips of the crust are destroyed, it is so long in being renewed, or growing down. It must proceed from the coronary ligament, and so gradually creep down the foot with a natural growth or lengthening of the horn, of which, as in the human nail, a supply is slowly given to answer to the wear and tear of the part.

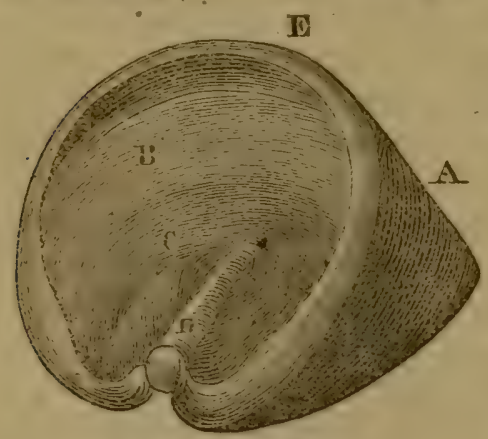

FIG. 4.-THЕ ноОF.

d. Outer surfice of crust.

I. Inner surfice of crust.

( $\therefore$ Upper surface of sole.

D. Part corresponding with the cleft of the irog.

E. Coronary band.

"Below the coronary limament is a thin strip of horny matter, which has been traced from the frog, and has been supposed by some to be connected with the support or action of the frog, but which is evidently intended to add to the security of the part on which it is found, and to bind together those various substances which are collected at the coronet. It resembles, more than anything else, the strip of skin which smirounds the root of the limuan nail, and which is placed there to strengthen the union of the nail with the substance from which it proceeds.

"The crust is composed of numerous fibres running at the toe in a straight direction from the coronet to the ground, but at the quarters, taking an oblique direction from tho lieel forwards. This 
comsuruction is hest calculated to enable the font, to expand when - it comes in contact with the ground, and by that exponsion, permit- fing the gradual descent or the bones of the foot, and obviating much concussion. The crust is thimer at the quarters and towards the licels, hecause those are the parts at which the principal expansion must take place. These fibres are lield together by a glutinous substance, but in such a manner as to permit a slight degree of separatiun, or to bestow the puwer of expansion on the foot; and when recentiy separated from the foot, it is an exceelingly chastic subsiluce, and very tough, that it may not chip and break with the violence to which it is often exposed.

"In stable management, it sometimes loses much of this toughness, and becomes brittle and liable to chip and break. Inflammation of the internal part of the foot, by the increased heat which is produced, will cause brittleness of the hoof; deficieney of moisture anr neglect of stopping will produce the same eflect. Many horses are peculiar?y liable to brittle hoofs during the summer; this is a very serions defect, and in some cases so much of the hoof is gralually broken away, that there is no hold left for the nails. A mixture of one part of oil of tar, and two of common fish oil, well rubbed into the crust and the hoof, will restore the natural pliancy and toughness of the horn. and very much contribute to the quicliness of its growth

"The wall of the hoof should be smooth and level: protuberaness or rings round the crust indicate that the horse has had fever in the feet; and that to such a decree as to produce an unequal growth of hom, and probably to leave some injurious consecfumeres in the internal part of the foot. If there be a clepression or lolluw in the front of the foot, it betrays a sinking of the coffin-bone, ancl a flat or pumicel sole; if the hollow be at the quarters, it is the worst system of bad contraction. .

"The inside of the crust is covered by numerous thin horny ieares, extending all around it, and renching from the coronary ring to the toe. They are abont 500 in number, lroarlest at their buse, and torminatir.e in the most delicate expansion of lum. 'Tly very much resemble the imer surfico of a mushroom. Iis front they run in a direction from the coronet to the tor, and towards the quaters they are more slanting from hohind forwart. They correspond with similar cartilacinous and fleshy leaves con the 
surface of the coffin-bone, called, from their construction, sensible .lamina, or lamelle (little leaves that have feeling), and the one being received within the other, they form tonether a most elastic body, by which the whole weight of the horse is supported.

"At the back part of the foot, the wall of the hoof, instead of being continued round, and forming a circle, is suddenly bent in. We do not refer to that bend which forms the cleft of the frog, but to a more sudden one, constituting the commencement of Tru BArs. The bars are, in fact, a continuation of the crust, forming an acute angle, and meeting at a point at the toe of the frog: and ine inside of the bars, like the inside of the crust, presents a continuance of the horny leaves which we have just described, showing that it is a part of the same substance, and helping to discharge the same office.

"It needs only the slightest consideration of the cut, or of the natural hoof, to show the importance of the bars. The arch which they form on either side, between the frog and the quarters is admirably contrived, both to admit of, and to limit to its proper extent, the expansion' of 'the foot. When the foot is placed on the ground and the weight of the animal is thrown on the little leaves, of which we have just spoken, we can imagine these arches shortening and wideuing, in order to admit of the expansion of the quarters; and we can see again the bow returning to its ratual curve, and powerfully assisting the foot in regaining its usual form. We can also perceire what protection these bars must form against the contraction, or viring in of the quarters. If they aro taken away, there.will be nothing to resist the falling of the quarters when the foot is exposed to any disease or bad management which would induce it to contract. Again, we see the security which they afford the frog; and the effectual protection which they give against the pressure of the lateral or side parts of the foot. Then appears the necessity of sparing and learing them prominent when the foot is pared for shoeing. It is the custom with too many smiths to cut them perfectly away. They iniagine that that gives a more open appearance to the heels of the horse; a seeming width which may impose upon the unwary. Ilorses shod for the purpose of. sale have usually the bars removed with this view; and the smiths in the neighborhood of the metropulis and large towns, shoeing for lealers; too often habitually 
pursue, without regarl to their customers, the injurions practice of removing the hars. The horny from, coprivel of its guard, will speedily contraet, and become elerated and.tirusisy; aud the whole of the hes], deprived of the power of resilite or re-action, which the curve between the bar and the crust afforis, will speedily fall in. Therefore, when treating of slocing, we shail lay it down as a golclen rule, that the bar's should he left prominent, and we shall show why it is of essential importance that the shoe :huuld rest on the angle formed by the crust and the bar."

The frog is a triangular-shaped portion of horny and callous :substance, growing between the "bars" of Ulic foot, naturally coming about level with the crust, and intencied to protect a softer and elastic substance inside, called the "sensible frogr," an intention too frequenily defeated by the itching which some blacksmiths lave to pare it off, wilhout rhyme or reason. Youatt hays :

"In the space between the bars, and accurate? filling it, is the rrog. It is a triangular portion of horn, projecting from the sole, almost on a level with the crust, and covering and defending a soft and elastic substance, callod the sensilic frog. It is wide at the heels, and there extending above a portion of the crust; narrowing rapidly when it besins to be confined betreen the bars, and terminating at a point at somewhat more than la! if the distance from the heel to the toe. It consists of two rounded or projecting surfaces, with a fissure or cleft between them, reaching half way clown the fiog, and the lwo portions again uniting to form the point or toe of the frog. The frog is firisly united to the sole, but it is perfectly distinct from it. It is of a difierent nature, lieing softer, and far more elusic; and it is secreted from a diflerent surface, for it is thrown out from the substance which it covers. Without entoring into many of the questions which have been agitated, with lar too much warmith among veterinarians, as to the uses of the fros, it is safficient to refer to our cut, and consider the form and situation of this part. It rery nuch resembles a wedge with the sharp point forward; and it is plitesd towards the hack part of tlis foot. The fout is seldom put fu: hi and flat upon? the ground, but in direction ciownward, yet somewhat forwaril; then the frog evidently grives safety to the tread of the animal; for it, in a mamner, ploughs itsolf into the grourd, and prevents the horse finm slippin. This is of consilerable consequence, 
when we remember some of the paces of the horse, in which lis heels evidently come first to the ground, and in which the danger from slipping would be very great. We need only refer to the gallop of speed as illustrative of this.

"ilhe frog being placed at, and filling the hinder part of the foot, discharges a part of the cluty sustained by the crust; for it supports the weight of the animal. It assists, likewise, and that to a material degree, in the expansion of the foot. It is formed internally of two prominences on the sides, and a cleft in the centre, presenting two concavities with a sharp projection in the mirllle, and a gradually rounded one on each side. It is also composed of a substance peculiarly flexible and elastic. What can be so. Well adapted for the expansion of the font, when a portion of the weight of the body is thrown on it? How easily will these irregular surfaces yield, and spread out, and how readily return again to their natural state? In this view, therefore, the horny frog is a powerful agent in opening the foot; and the dimunition of the substance of the frog; and its elevation above the ground, are both the cause and the consequence of contraction: the cause, as being able no longer powerfully to act in expanding the heels; and the consequence, as obeying a law of nature, by which that which no longer clischarges its natural function is gradually removed. It is, however, the cover and defence of the internal and sensible frog, at which we are not yet arrived, and, therefore, we are at present unable to develop its full use; but we have said enough to show the absurdity of the common practice of unsparingly cutting it away. To discharge, in any degree, some of the offices which we have assigned to it, and fully to clischarge eren one of them, it must come in occasional contact with the ground. In the unshod horse it is constantly so; but the additional support given by the shoes, and more especia!ly the hard roads over which the horse is now compelled to travel, render this complete exposure of the frog to the ground, not only umecessary, but injurious. Being of so much softer consistence than the rest of the foot, it would be speedily worn away : occasional pressure, however, or contact with the ground, it must have.

"The rough and detached parts should be cut off at each shoeing, and the substance of the frog itself, so as to bring it just above or within the level of the shoe. It will then, in the rlescent 
of the sole, when the weight of the horse is thrown uprom it in the puting down of the foot, descend lilicwise, and pressing upon the ground, do its duts; while it will be defended from the weal, and bruise, and injury which it woulil rece:re if it came apon the ground with the first and full shock of the weight. This will be the propei guide to the smith in operating, and to the proprieter in the directions which he gires; and the latter should often look to this, for it is a point of very great moment. A few smiths carry the notion of fiog pressure to an absurd exicnt, and leave the from beyond the lerel of the sole; a practice which is dangerou: in the horse of slo'v draught, and clestructire to the liackney or the hunter; but the majority of them err in a contrary way, and, cutting off too much of the frog, lift it above the ground, and destroy its principal use. It should be left just above, or within the: -level of the shoc."

The crust and the frog are seemingly all that the horse-shoer has to deal with, but it is easy to see that through them he cau make himself felt for good or evil on the whole font and the anima! it belongs to. The crust is perpetually growing, and it a horse's shoes fitted him well at first they will be sure to become too sman if kept on too long. Some authoritios fix upon three. or four weeks as about the time that a shoe should be worn without refitting, and this is perhajes near enough, but horses rary as much in the rapidity of the growtly of their hoofs as men do in the growth of their nails, and arbitrary rules must not be ailowed to take the place of experience and ob:servation. Notice always how your own farticular horse wears his shoes and how his howfs grow, not rxpecting, even then, to find him always uniform in sickness and in health and in all species of work.

It is strange that it should aver be forgotten by either smith or owner that the horny crust of the horse's hoof must alsolutely not be used up in shoeing, no matter how frequently that is lone. more xapidly than the natural growth will malie gond. Farelessness of this principle is certain to protuce lameness in one way or anotheip, and the bo-t you can then hope is that long rest and illoness will grive the abused foot another chance.

The tibres of the horny matter of the hoof, when once separater!, will never again unite, nor can any sand-crack or other bruise (1) lamination be healed, otherwise than by protecting it from increase 
and waiting for the growth of the crust. From this it follows that the sulin must not be jormitted to use either knifo or nails too freely: the latter is too oiten lost sight of in shoeing for heary work or hauling on pavements.

m!le reater purt of the shoes at present used in this country are mure by maclinery, or rather, a species of "blank" is marte which still requires especial slill and caro in selecting and fitting it for use. There can he no donth that the employment of macline made shoes is a great mechanical gain, as well as a saving in money, in riew of the very imporfect manner in which so many of

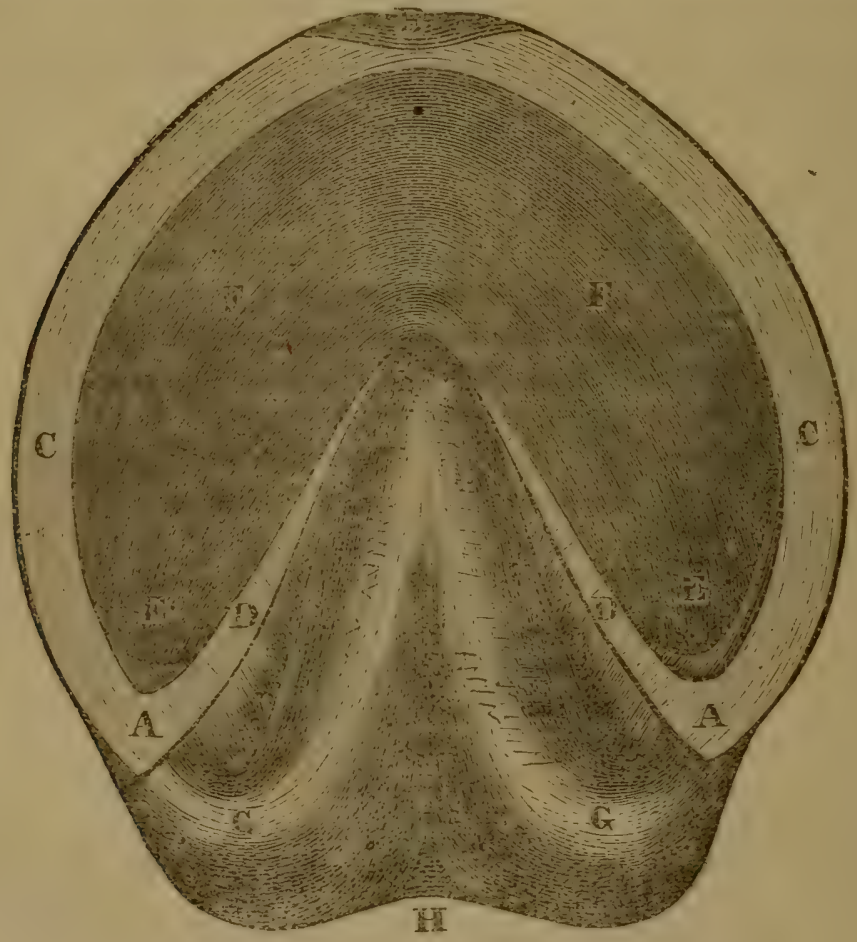

FIG, 5. -A SOUND FOREFOOT PRERATED FOR THE SHOE.

A. The heel of the crust.

B. The toe.

C C. The quarters of the crust.

D D. The bars as they should be : eft witis frog between them.
E E. Live angles between the hes: $:$ mul bars where corns appear.

F F. The concave surtace.

$\mathrm{G} \mathrm{G}$. The bulbous heels.

II. Cleft. 
our smiths hare leamed their trade, though at first it encountered a tremendous array of self-conceit and prejudice. Every smith, howerer, even to use to adrantage a shoe mar?e by another man, ought to be able to prodice a frefect one with lis own hands. Ilow else can he be said to understand the principles involved, or how, even more esprecially, will ho be able to select his shoes for the feet of any one particular liorse, oi pioritle for the local peculiarities which may be recuired by disease, deformity, weakness or special service?

Watch your farrier, and if he goes ti) work too recklessly, jerkilıg off the shoes with a rude hand, check him. Crooked naiis, if dragged rudely through the holes in the hoof, w?!l enlarge them an! the shoe will loosen more easily. 'Lhe re-shoeing begins with the removal of the old shoe.

Note now, carefully, the condition of the hoof, and if there is a call for any otlier attention besides simple s!neeing. If not, and a!l looks firm and healthy, don't have too much cutting done, hut pare the crust and hars about down to the outer edge of the sole, without taking one shaving from the sole, the frog, or inside of the bar:s Any loose matter may be scraperlavay, so as to leare the fing and sole clean and heaithy. The reason for this is that your olject should be to reduce the foot simply to such a state as natural and healthy wear would leave it, if the horse wore ne shoe at al!, and then to fit your iron protector with a view to the further preservation, as far as may be, of that natural and heaithful shape and condition.

The little inequalities left by the knife on the fare of the liorf are removed by touching them with the hot shue, lut there shouki not he too much of this, as it snftens and disintegrates the horn. $\Lambda$ few experiments will convince you of this.

The number of nails to he used musi rary somewhat, ant that is a matter for the exercise of sound judgment, but they should be as few as may be, considering the work to be done and the hoof to be shod. For ordinary rwal work six will genemally be found chough. The American erlitor of "Stonehenge," an English writer" "f value, has given some excillent hints on horse-shoeing, thoughe it could be wisherl that he hat said more ratier than less. Je remarks concerning his own custom :

"Now, take a horse whowe how have been slowly growing in 
length for a montl, every motion of his body trained to accord, pull off his shoes, which will be found (owing to the forward growth of the hoof) farther from the heels than when first applied, pare away the crust (lown to the sole, cut out a big nolch at the toe for a clip, set the new shoe back within the front of the foot (more on the forefeet, as they are supposed to grow faster), then rasp off the outer part of the toe back to the shoes, and clench the nails as tight as possible. This is a cornmon mode of shoeing; his shoes are too small for him; he swings into a trot with the usual body motion, but the feet, all shortened, fail their part, while the forefeet, diminished more than the hind, are not thrown out quite as far, and the horse, uuaccistomed to the change, dwells too long on them to cscape a blow from behind: Weariness and laziness will also cause forging, by a tardy movement in front, and stumbling, by a failure to raise the toe suficiently to avoid scrubbing the ground when thrown forward.

"It is too common, especially in cities, among rlraught-horses, to use up the lower part of the crust too fast for its growth. If the litman finger-nail be pisced with a fine needle in the manner of a horse-shoe nail driven tirourh the cust of a hoof, it will be observed that the hole will remain, until the growth of the nail has carrich it beyond the flesh; that is, the fibres of horn once separated will uever unite. IIorses userl for heavy work are shod with heavy shoes, thick toe and (quarter clips, high calks and steel toes, and either because of tho severe strain on the stones, the weight of the shoes and nails, the leverage of calks and toes, waste of crust to accommodate clips, or of all combined, they require shoeing about once in thire weeks, and frequently oftèner. At each shoeing, a little more crust and sole is taken off of the ground surf'ace, a few more holes marle for nails driven into old ones, enlarging the aperture by working about and bending under the clenching iron). The surface of the erust is again rasped, diminishing the thickness, new furrows macie to accommodate the clenches, and the horn burned and softened by a hot shoe each time. The blacksmith will insist that all these operations are necessary, but the fact is, he is using un matorial too fast, and we leave it to horseowners to judge by experinent, how these operations nay be modified. The French method of bringing the points of the nails out low down on the surface of the hoof, appears rational, as it 
destroys the vitality of the erust to a less ilecrree than our custon, and leaves a gieater jropurtion of sound fout to bear the shocks.

"Our practice has been, affer remoring the old shoes (with care not to enlarge the old holes by dracrging crooked nitils througl them), to pare off the crust and bals well duwn to the vuter edge? of the sole, without taking a shaving from the sole, frog or insirh? of the bars. If the crust has not been broken by wear, this learcs the foot as netr its natural shape as possible, and a shore murt be in:? to to fit it. For roadsters, a narrow, light shoe is fitted to the critst in lencth and width, then made perfecrly level, without twist o: i) ritchell burs at the nail holes, and while sufficiently hot, slightly touched to the crust, to nark any inequalities that may have been left after paring. Six nails are used, three on each side, divilin:s the sprace from about an inch from the centre of the toe, to the centre of the quarters. The nail holes are set well back from this outside edge, and mad, straight through the iron : the nails ar: small, smootherl off with a hammer, and slightly bevelled on ons sicle of the point; the position of the holes in the shoe brings the nails git low down on the surface of the crust, but care must b:? \{aken lu start them in the centro of the holes, that the foot mity not be cramperl or forced out of its natural shape. The projecting nail points are filed close to the hoof, that they may be brolien off without twisting the nail, or enlarging the hole in the crust; the nuils are then driven up, and the clenches turned over anit hammered down.

. "To rasp has been used, no crust wasted by mutilation for clips", ant ist little injury by nail holes; if the nails be of good iron, thry are sufficient in number, and the light clenches on a sounet fout will hold the shoe perfectly tight, and will not cause abrasion of the legs in travelling.

"The fuot presents what we micht call a beantiful fit, the twuler" part of the frog is protected by the thickness of the shoe, while as: it is renewed from within, the outside will be worn off by frietion, and nature will keep it exactly low enough to obuin its necesary exucise; moreover, by driving the nails straight throunh tha willle of the lools in the shoe, the fort will be free from that disaxienble, cramped forlin when the nails are sturted at either sirle of the hole in the inn.

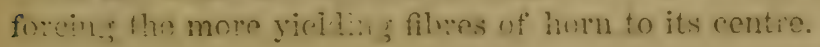


"There have beeil many forms of shoes recommended by different authors, but few of which are used in this country. The French shoe has a convex ground surface, and the foot is fashioned to it, by learing the quarters full, andue crust sloped off towards the toe and heels. Why the bearing situuld be taken off the heels we cannot imagine, and forcing the quarte:s to bear an unclue amount ot concussion would apparently induce quarter crack, but haring had no experience with this shoe we may be wiong in our conclusions.

"Another fashion imitates an old shoe worn off at the toe, which is certainly an advantage to roadsters, as it would be to us, if we could buy new shoes to fit our feet exactly like the old ones. Somie write:s advocate nailing the shoe only upon the outside quarter, or with but two nails on the inside, toward the toe, with the idea of allowing unimperied expansion of the crust when the foot strikes the ground. Inasmuch as nails injure the crust, the practice of usiug as few as possible is wise, but we have been unable to discorel any expansion of the anterior half of the ground surface in hoof that have never been shod. A careful examination will convince any one that there is no mechanical necessity for such spreading, and from the nature of the organization of the foot, it is simply impossible; all the spring needful to the front of thic crust.is gained by the elasticity of its fibres. The line of bearin? of the lower part of the foreleg, is directed behind the centre of the foot, and the yielding points of the frame work are the pastern, coronary and navicular joints; as the upper part of the coronary bone works backwarl and downwarl, it, with the action of tile tendon, slightly spreais the heels laterally, and the whole cru:t partakes of the morement, diminishing in effect towards the toe ; were the foot completely inelastic, the motion might be detected at the quarters, but the whole of a healthy foot is of a yieiding nature; the fatty heels, in particular, may be compressed like corl; While the frog resembles a piece of india-rubber, and there is a spring in every fibre of the crust. These conditions so far distribute motion, that there is practicaily none in the ground surface of the crust forward of the centre.

"From the fact of this style of shoe allowing free expansion, its advocates proclaim it a preventive of contracted heels (which, unfortunately, is so provalent among shod horses); but if, as we 
suppose, there be no spearling of the fiont part of the crust by pressure, a shoe nailet only at, and forward of the quarters, will not interfere with any latural movement of the heels.

"This disease (contracted heels), apuears to be an absorption or waste of a portion of the frog and fatty hecls, accompunied by an undue secretion of crust at the posterior part of the jout, encroucicing upon the province of the softer tissue of the heels.

"Many reasons have been assigned for this disturbance of the natural nutrition of the different parts, all or none of which may be correct, for mo theory has yet been so clearly demonstiated airi proven, as to leare the causes and nature of the disease beyond a doubt, but we have never known any tendency to contraction. in horses that have been shod in such manner as to allow the frog a fair amounc of exercise, indicated by its position.

"An india-rubber shoe intenderl to be userl as a cushion between the iron and the foot, has been designed, patented and tried, within the last two or three years, but we believe has failed to give general satisfaction. The rubber mashes out in a short time ly concusion, and leaves a loose shoe. Good sole leather is much more durable."

Those of our rearlers who choose to exanine this ant!ıor, w!!l fint much in it that is valuable in this country as well as much that is purely English in its application. 


\section{CHAPTER TWELFTH.}

\section{HINTS ON HARNESS.}

Harness for work-Bad harnessiug a waste of power-Friction and soresWoodruff on pulling-Tricks in work-Relief from harness in rest.

Tne horse who has been well stabled, whether with or without any pretence to elegance; well fed, well groomed and well shor, may fairly be cunsidered in a good state of readiness to be liarnessed for his work. And here again it will be necessary to ask what is to be the nature of that work or use. We make and use in America the very best and the very worst of all possible horso furniture, and we have developed all sorts of doctrines concerning it. For our own part, we have no idea of attempting any inccmprehensible scientific disquisition, but would simply suggest tirat the body of the horse is a sort of machine, and that the wagon or plough is another, and that if the former is a propelling power the main aim is to employ it with as little waste as possible. Good larness may be very badly put on, so as to seriously interfere with tiie amount of power which the horse can apply, and at the same time with his comfort and endurance. Moreorer, recklessness of a Iew slight and inexpensive appliances, and a little care, when thro are needed, on the shoulders, back and other exposed points, will often permit the creation of unsightly and annoying if not obstincito and dingerous galls and sores. The first point to make here is, that the collar must fit,--that is, it must apply its surface as erenly as may be to that of the muscles upon which it is to press, and it should be as carefully stuffed and as free as possible from inside rigidity. The point at which the traces are attached should also be carefully selected so as to secure an even bearing. By this means, as will easily be seen, the collar is prevented from pressing with undue weight upon any one point, and the whole limb will be less rapidly wearied, while there will be much less danger of any abrasion of the stin. A good deal the same rule applies in fitting on a saddle, and, generally, wherever it is necessary that there 
should be much pressure or friction it should ho as much as possible distributed over the surface and reliered by solt heariners. This is not even so much a question of liumanity as it is of cconomy in working power. Its especial application can only be made to advantage with the horse and the hurness both before you, but it should not be difficult then.

The horse and his hainess should both be apportioned to the work to be rlone, and as a general rule it should be "heary for" heary, and light for light." That this rule is not to he carried too far, however, is well known to all horseman. No less an authority than IIrAM WoDnREF remarks, in tiat valuable and entertaining work, "The 'Trotting IIorse of America :"

"The ability to pull weight is a quality of exceeding value; and when it is found in connection with speed and stoutness, wo may say that the three prime characteristics of the harness liorso are obtained. It is to be remembered that the ability of which I speak is that which can pull at a great rate; so that putting on extra weight, up to a reasonable point, shall make no very urent difference in the performance of the trotter. Almost any hrore can pull a moderate weiglit at a slow pace, on a rood roarl, hit those who can take along about four hundred younds and kapp the pace for two or three miles, are, and always have been, ra!her scarce. There is a great difference in the ability of fast trotter's in this respect; and the common notion that a great bulky horse is best calculated to do so is a fallacious one. For a draught horse, rreat size and bulk, to throw an immense steady strain into the collar, nay be valuable, but when the weight is to be taken along at a meat rate, other things are of nore importance than mere size. In the first place, then, as to height, I do not think that a tall horse hias any advantage in this regard over one about fifteen hands and an inch, or fifteen hands two inches high. The tall horse is apt to be leggry, and his height often comes from extra length in the canon bones, which multiplies no power. Length in the arms, shoulders, thighs and haunches is a different matter. It follows that the extra height of a horse may be rather a disadvantage than the reverse, in regard to pulling woight at a fast rate.

"Nere bulk is also tiseless. Everyborly must have seen horses, big enourh to pull a ton, to look at, aud able to trot fast in a sulky or to a slieleton wagun, but unable to act to arivantage to thrce or 
four hundred pounds. The weight-pullers, as a general rule, are of merlium size, with a fine, cuick stroke, not orerlong, and they hend the knee well. They need to be spirited yoers, kecping well up to their work all the time; and, unless their temper and pluck are both good, they will sulk, or give up from faint-heartedness when they feel the weight and the speed begin to tell. But though mere bulk is useless for the purpose, a fair amount of substance is required, and it will be found in nearly every case that, thoigh the weight-puller may not have a large frame, he possesses a large muscular development. Long striders are seldom good at weight. Being greatly extended, with a load behind to be pulled along, they are unable to recover and shove their haunches in quick, without extra exertion, under which they soon tire. Here thes more than lose in time of stroke what they gain in space, and loiter, so to speak, in their action."

The great trainer is speaking more especially of fast stock and trotters; to be sure, and it is a point to be made to best adrantage, in some respects, when you are buying, but is by no means deroid of value when you come to consider the important question of work and endurance, and what jou are to expect of such stock as you may have.

If now your harness is casy in its fit and is well arljusted, if your traces pull evenly, and every strap and buckle seems to be in its place, you are in a farr position to discover before long, what tricks your horse rnay have in work, if you do not by careful thinking also discover that you as a driver are the more faulty and vicious animal of the two. That the latter is generally the case, a somewhat extended observation strongiy inclines us to believe. A great difficulty is that both with men and with horses the worst defects are of inborn temper and of ingrained habit, and are exceedingly difficult to cure. These will be more particularly dealt with in the chapters on breaking and training. Much also that pertains more especially to the saddle horse will be reserved to a more appropriate place.

Botil as to harness or saddle, howerer, please bear in mind that when your hour of rest comes and your quarlruped servant is also. pernitted get his breath and his food, you cannot do him a more refreshing favor than to off with the leathers, etc., against which he 
las ben pulling. He will be worth all the more for it when you start again, eipecially if you will give him a quick rubbing with a wisp of stuaw. With horses nuthing really pays sg well ats thoughtful kinduess. 


\title{
CHAPTER THIRTEENTH.
}

\author{
STABLE '1 RICKS AND VICES.
}

Stall kicking-Weaving-Tearing the clothes off-Vicious to clean-Crib biting-Windsucking-Refusing to lie down-Pawing-Quidding-liolling -Biting.

IF there is one point more than another at which the horse most strikingly developes the analogy between his own character and that of his human master, it is in the ease and realiness with which he acquires, especially while young, an endless vatiety of tricks and vices, small and large. Whatever these tricks and vices may be, it is of the utmost importance to know them all, for the horse clings with much more than human obstinacy to anything which he has once learnel. Some of them are of very little account; some are only rexatious and annoying; while others, by no means few in number, tend to rencler the animal who has acquired them, more or less unsafe, and some constitute positivo legal unsoundness.

The gradation from mere trick to disease and legal defect is sometimes slight and hard to follow, as will be seen, but both in buying and afterward in keeping there is a good deal to be guarded against and accomplished by watchfulness and precaution.

Attention is first to be directed to what may be called "tricks and vices of the stable."

Prominent among these may be named "stall kicking," a habit which may be acquired by any horse, at any time of life, but which, once formed, is extremely difficult to cure. With somo horses it comes and goes, at irregular intervals, as a sort of intermittent ugliness, a return of which is very apt to be brought on by flies, undesirable neighbors, a strange stable, or other circunstances.

By no means play with or in any way teaze your horse in the stable, unless you wish to teach him to kick, for it is not always the horse's fault or a sign of original bad temper. In this matter 
mischierous boys will sometimes be agents of a good deal of harm if allowed the run of the stabie. Nares are more liahle to this vice than geldings, and they are always worse at the beginning and end of their time of bcing "in use," and those who are very gool and quiet at other seasons will then hecome, at times, perfectly outrageous, and must be forcibly restrained to prevent their doing themselves harm.

Kicking horses not only make their stalls dangerous places to cnter or work in, but are rery apt to be perpetually laming themselres more or less severely. When a horse has just begun to acquire this habit it may do some good to fasten thorn bushes or other prickly things where his legs will be sure to strilie them, and lhe is apt to make up his mind that "it is hard to kick against the pricks." A severer remedy is to attach a long, heary piece of wood to a chain and buckle it above the hock so that it will hang about half way down the leg. If he kicks against this he hurts himself, and will generally stop for that time. This is not a safe cxperiment with spirited or obstinate horses, who may do themselves serious injury before they will give in. Few horses kick with both feet at once in the stable, and a pair of lobbles buckled at the hind fetlocks will in most cases complel quict as long as they are worn. Some writers recommend a narrow strap buckled tight iust above the hock, as it will cause great pain if the horse tries io kick with it on, but it hurts even worse if he tries to lie down, and should not be tried till other expedients have failed. In very lad cases, tying up the foreleg is often resorted to, but this, of course, cannot be continued and is only less annoying to the horse than the vice itself.

Some horses will stand in the stall with a perpetual swaying motion of the head from one side of the manger to the other, as if the restraint was unendurable. This is WEAVING, and is peculiar to animals of an irritable nervous system. It does no special liarm of itself, but it is an indication of a fretful disposition. It cannot be cured.

Many horses, of a similiar organization to those last named, cal: hardly be induced to bear any covering on them in the stible, and where it is desirable that they should be clothed, thei: habit of tearing off everything that can be put on them is an ugly one. "Stonehenge" says: 
"TEARING TIR CEOLIIES OFF is by no means an unusual stable habit, and it is one very difficult to cure. There are two effectual preventires, howeror : one of which consists in the regular employment of a rough horsehair cloth, made like that for hops, outside the rug, and which is so disagreable to the tecth, that no horse will attempt to tear it; the other is carried out by means of a pole of ash, about three-quarters of an inch in diameter, with an iron eyc attached to each end. One of these is fastened, by means of a short leathern strap and buckle, to the side of the roller-pad, while the other has a strap or chain about a foot long, which attaches it to the head collar. The pole should reach about fifteen inches beyond the point of the shoulder, and it should be fixed on the side which is generally uppermost when the horse lies down, so as not to be under him in that position. It is a very simple and cheap apparatus, and any village blacksmith can make and apply it."

There is a rery great difference among horses in the relative tenderness and sensitiveness of their skins, and, while some will hardly deign to notice even the whip, others will be driven lialf crazy by the touch of $\mathrm{a}$ fly. A little disregard of this in the beginning of his training will frequently malie a horse that is very good-natured, every other way, vicious to clean, so that it is as much as a man's life is worth to come near him with a brush and comb. It is doubtful if this rice is ever the animal's own fault, for horses generally are inclined to take kindly to gentle and skillful manipulation, and so true is this that a cure may generally be effected by frequent dressing with a light hand and a soft brush or eloth.

Crib.bitirg, as it is called, is apt to be or become a very serious matter, not only to the manger and the food in it, but to the horse himself. It is destructive of the teeth, in the first place, and it may be regarded as both a cause and an indication of such a state of the stomach as renders the horse more than usually liable to colic.

In crib-biting the horse seems to desire some "fulcrum," so to speak, for the muscles of the neck to work on while encleavoring to discharge wind from the stomach. He seizes the manger or other available object,-it may be a fence rail,-with his teeth, stretches his neck, appears to "clioke," or work the muscles of his throat, and then follows more or less of "grunting and sucking." Crib- 
biting horses are frequently rely good workess, hough apt to the tinin, but they are sulject to ugly colic turns, win by rew of the extra wear they give their teeth are likely, not only to look older than they are, but also to actually be older, so far as use and endurance are concerned.

Althongh it is a common opinion that crib-biting is the consequ'nce of a clisease of the stomach, we are inclined to consider it, in the first place, at least, as much a habit as tobacco chewing is in man. It is very contagious, and if one horse in a stable has it the rest are pretty sure to follow him. Other "diseases" will yield more or less to medicine, but this will not, and it is of no use to turn the horse out to pasture. So long as a fence rail is to be liad to gnaw on and strain against, the confirmed cribber will not at all miss his manger. Various causes have been given for the formation of the habit, but only two seem reasonable: imitation and idleness. One horse will do what he sees another do, or if he is tied too long uselessly in his stable there is no telling what he will not do, with teeth or heels.

A common "preventire," but which is by no means a "remedy," is to buckle a leather strap so tightly around the neck, just hehind the jaw, that, when tho horse attempts to crib, he tightens the muscles of that part, and these being pressed against the strap occasion such pain that the act is not completely carried out, and eren if it is, the first time it is tried, the horse remembers the unpleasant feoling, and hesitates to repeat the dose. In ordinary cases the strap is left comparatively loose, so as not to prevent swallowing with ease, or to check the flow of blood from the head, through the jugular veins to the body. Greater tightness, which alone is of any arail with confined cribbers, has a tendency to produce other diffeculties of head, throat and lungs, and is of little value.

It is of no use to coat the manger with tin or wool or tar, the "cribber" will soon get used to them all, and cast iron, if it were there, would only give him a better chance to destroy his teeth.

There are but two entirely thorough and effectual cures for cribbing, and no others need be bothererl with. The first is a box without a manger, or any other bar for a horse to put his teeth on, ant in which the foed, of whatever kint is: placed on the ground. Tlis: may waste some fuol, hut the prevention is perfect. The 
second is the "bar-muzzle," of which there are several very good patterus, consisting of añ iron-frame-work, covering the lips and nose, and suspended from the head by a leather head-collar, so that the lips can reach the corn or hay, but the teeth cannot get at tho edge of he manger. There is no harm in this contrivance, excapt that is likely to lengthen the time consumed in feeding. riat, however, is no disarivantage to either horse or man.

Some horses seem to be taken at times with a crazy desire to devour their litter, but this is not a permanent vice and can generally be readily cured. It.implies that the horse has been kept short of hay, or what we call in the West, "roughness," or that he has been stabled too long. A temporary "preventive" is thirst, caused by salt or otherwise, which will prevent his longing for the cliy, coarse litter but a cure will be found in green soiling or $a$ vacation on good fresh pasture land.

"Wind-sucking," says Youatt, "bears a close analogy to cribbiting. It arises from the same causes; the same purpose is accomplished; and the same results follow. The horse stands with his neck bent; his head dramn inward; his lips alternately a little (o)ened and then closed, and a noise is heard as if he were sucking. If we may judge from the same comparative want of condition, and tho flatulence which we have described under the last head, either some portion of wind enters the stomach, or there is an injurious loss of saliva. This diminishes the ralue of the horse almost as mitch as crib-biting; it is as contagious, and it is as inveterate. The only remedies, and they will scldom arail, are tying the head up, except when the horse is feeding, ou putting on a muzzle, with sharp spikes towards the neck, and which shall prick him whenever he attempts to rein his liead in for the purpose of windsucking."

A bad habit for any horse to acquire is that of not lying doun. Ile is apt to be troubled with swelled legs, and his fault tells severely on his pluck and endurance on a journey. Noreorer, it is sure to aggravate any tendencies he may hare to, weakness or discase in his feet and legs, for very obrious reasons. The case is to be looked for in his having been previously too closely tied, ami the cure, if it can be effecter, is to be sought in the opposite direction. Tire him completely out for several nights in succession, and then, aiter a gooil grooming, show him a fresh, well-made bed 
in a loose box, or in his own stall, with a long, loose halter, or with none at all. Il won't take him Inug.to learn a lesson from nature and wearingess.

PAwrog is another bad stable habit, and we have ownerl several horses that quite distinguished themselves at it. It is a vice of nervousness, and is sure to be increased by a noisy or unpleasant "horse neighborhood." . It wears out shoes, hoofs, floors, and not unfreduently results in damage to heels and legs. Ifardwork is a good remedy for most cases, but now and then an inveterate pawer must be absolutely shacklerl to keep him fiom hurting himself. It is a habit that comes and goes, and for which there is no remedy.

If you find that your horse, after taking his hay into his mouth, chews it somewhat and then allows it to drop from his mouth, ho is quidding, and the result will be poor work and emaciation. It may be caused by irregular teeth which will not let him grind with comfort, and this can only be cured by the rasp of the veterinary surgeon, but it is more apt to be the result of sore throat or sore month, and these must be looked after. As soon as the cause is removed the "quidding " will cease.

"Rolliag" when a horse is loose in his pasture or in the stabie yari, is not only an agrecable amusement, but it has it:s nsess. When, however, any misguided quadruperl attempts it in the stabie he is apt to hurt himself. As a general thing it camot be called a confirmed "trick," and is only an indication that the poor fellow has been liept up too long without a chance to stretch himself. I few dlays in the field, or, if that cannot be, a vigorous rubbing of the shoulders, back and loins, will take away the "stretehy" feeling which makes him want to roll. If the case is really a "trick," it can be absoluteiy preventerl by shortening the halter so that the horse cannot get his heal on the grominl for a "purchase" to roll with. Some inveterate rollers can be restrained in no other way.

IIorses which aro naturally evil tempered and vicious when at home in their own stables are comparatirely rare, and conserpuently, in nine cases out of ten a "biter" has heen made so by defective education. He bites out of revenge or in inaginary self-defenc:? Kinchess and firmness will generally cure the propensity to bite, but fear never will. If the habit has become confirmet, or tl:horse is of an ugly and treacherous disposition, the muzzle is 11 ... only safoguard, to be worn whenever tho animal is not feecling, and perhaps even then. 


\section{CHAPTER FOURTEENTH.}

OUT OF DOOR TRICISS AND VICES. -

Shying in harness-Rearing-Kicking in harness-Tumning away-Lying down in harness-Hard pulling-Overreach-Cuttin - Stumbling-Balking.

Is tho previous chapter we have hinted at a few of the acquired tricks and bad habits of horses which manifest themselves in the stable. The list cannot, of course, be exhausted in a treatise like this, because, except in a few general outlines, such peculiarities will vary with the breed, training and special idiosyncrasies of the individual horsé.

In dealing with them, as with those of which we are about to speak, it must be taken for granted that the man will not put himself on a level with his brute property, but will assert his superiority by superior patience, pluck and good temper, trying in each case to merit that confidence and affection which is worth more than anything else in securing good behavior from the horse.

The out-door tricks and vices of horses are sufficiently numerous, but common sense and average intelligence will have little difficulty in tracing them, as a general thing, to defects of natural disposition, of education, of physical structure, or to the consequences of accidents.

Of all equine tricks, in harness or under the saddle, that of SHYrig is the most common, the most complicated and the most difficult to deal with. Its best prevention is attended to in the early training of the coit limself, but its causes, then or in after life, are innumerable.

Defective sight, rendering the horse uncertain of his neighborhond, and distorting the objects presented to his rision, is very likely to produce this fault, especially in inigh-tempered horses. In such cases, if you can manage to cure the eye you stand a fair chance to cure the shying.

Oftener, shying recults from nerrousness and timidity, stimulated 
by bad management, and tho scisitireness frequently scems to concentrate itself upon one class of objects. We owned a horso once whom no punishment could force by or orer a wisi) of flutterinir straw or a bit of loose white paper, and another to whom a bridge was the embodiment of all terror. There is no end to these splecial peculiarities, and they can generally be traced, or could if the animal's private history were kwown, to some apparently unimportant episode in early life.

Besides these there is an immense amount of shying from moro cunning, "make-believe," or habit. Somo horses have their little pet terror that will always give then an excuse to jump aside, or turn around unless they are too tired, or are going homewand, or are too positively sure of a keen lash or a sharp spur. We have had some curious experiences with such horses that soon learned better thais to try their cunning little tricks with us, but would tako to them again at once if ridden or äriren by strangers.

The cure, in any case, can only be accomplished by a combination of firmness and good temper, which is only too rare. On no account should the horse be punished after he has passed the object at which he expressed alarm by his shying. When he shics, stop him at once, if possible; make him face the object of his terror, and encourage him, witlout any force or riolence, to approach it and smell of it. Use all the art jou are possessed of to persuade him that his fright is groundless. If you choose to so abuse him that he will always afterwards associate that object with additional pain and discomfort, it will be your fault if he shies more promptly the next time he meets it. If you flng or spur him the moment he is past the object of his fear, don't blame him if you have giren him a perpetual hint to run under like circumstances. The voice is better than the whip, and the land still better.

If an otherwise gentle and manageable horse exhilits a disposition to REAR, whether in harness or under the saddle, attention should at once be giren to his mouth and bit, as with a sore mouth and too sharp a curb, it is quite easy to teach that which becomes a very unpleasant and often dangerous vice. Thearing, espreciully in young horses, is frequently the effect of mere playfulness or inexperience, and if so it can be remedicd by the ordinary martingale and a little hard work. Very serere mensures are, scmetimes aciopted with confirmed "rearers," such as linocling then 
down by a blow between the ears with a loaded whip, which may cure the vice and may produce poll-evil ; or pulling them gontly over backwards, if under the saddle, to the imminent peril of spine, loins and neck. If the horse's neck is broken he will not rear any more. There have been many mechanical appliances invented to prevent rearing, and in isolated cases no doubt some of them liave met with success, but no general recommendation can be given. It does not constitue legal unsoundness, but it assuredly is a "vice" of the very first water.

KICKING IN IIARNESS, or rather a tendency to kick out of it, is a very troublesome trick, generally the result of bad training. With some horses it is merely an expression of superabundant spirits, and a little extra work is all the remedy required. With others it is the outbreals of inherent vice and ugliness, and can only be dealt with by strong harness, kicking straps, and a liberal outlay of the lash. With mares the tendency to kick is often only periodical, and a merely sexual indication, and the animal should accordingly be dealt with mercifully. If the mare is in real trouble it would be, better to take her out of harness than to ruin her temper by flogging her.

A prominnent English writer on horses, sagely remarks, "RuNNING A TTAY is too well known to need description."

We should think it was, but it is too dangeraus a vice to be passed by. If a horse is known to be an inveterate runaway, he is legally vicious and unsound, but this is generally hard to prove. After even one runaway tho animal. must be watched, and each successive escapade makes him the more dangerous. Horses who only run for the fun of the thing are apt to choose a light load, and a weak or timid driver; such runaways are more annoying than dangerous, unless they choose a crowded street to show off in. More frequently, however, a runaway is caused by sudden fright, which seems to generate a species of madness or hysteria, even in hitherto trustworthy horses, which only terminates with a grand smash-up or other exhaustion. Not a bad idea, if the place will admit of it, and there is room enough, is to give the too rapid traveller more running than he likes, and keep him going till he is altogether sick of it. This will often work a cure in horses who only run for the fun of it or from vice, but in those who are really seized with the running fright it will do little good. Such horses 
should never be used without paying special attention to the soundness and strength of the harness, and the driver should bo on the lookout to check the very first symptoms of insubordination. Great care should be exercised in selecting bits for restive horses, in order to have them sufficiently powerful in case great checking power is called for, and yet so that it shall not excite the animal's temper by continually hurting him. The curb should only be used when it is absolutely necessary.

If a horse is inclined to lie doan in harness or under the saddle, whether the trick is the result of laziness or ill-temper, it can best be met by sharp and sudden sererity. Cut quick and hard with your whip every time the experiment is tried, and in most cases the horse will give up trying it with you.

A very bad habit with some horses, particularly roadsters, is to gull too severely on the bit, as if they meant to draw the whole load with their mouths. This is a result of bad training in too light a wagon. The aninial was perhaps never fairly taught to pull from the shoulder, and it may be too late to teach him, though a season of hard pulling with a loose check rein, will sométimes work wonders. In many horses this is a symptom of a disposition to run away, or is a result of previous serere struggles with strong handed drivers. It should be looked out for in buying a road horse, as unless it can bo cured it entails no end of unnecessary and disagreeable work on both him and his master.

OTERREACI is caused by the toe of the hindfoot knocking against the shoe of the forefeet, and every one is faniliar with tho disagreeable "click" so produced. In the trot, one foreleg and the opposite hindleg, are first lifted from the ground and mored forward, the other foreleg and the opposite hindleg remaining fixed; but, to keep the centre of gravity within the base, and as the stride, or space passed over by these legs, is often greater than the distance between the fore and hindfeet, it is necessary that the forefeet should be moved alternately out of the way for the hinclfeet to descend. Then, as occasionally happens with horses not perfectly broken, and that have not been taught their paces, and esprecially if they have high hinder quarters and low fore ones, if the forefeet are not raised in time, the hindfeet will strike them. The forefoot will generally be caught when it has just begun to be raised, and the toe of the hindfoot will meet the midule of the 
bottom of the forefoot. Overreach sometimes may be simply the result of bad shoeing, and can be readily remedied. Even when it is not it can bo best provided for by skilliful fitting, as it is very doubtful if any wild horse is ever so troubled. This is peculiarly a "farrier's vice," and it does not constitute " unsoundness."

Cutring depends either upon the legs being set on too near together, or on their joints not acting in a proper hinge-like manner. Many horses cut when in low condition, but are quite free from the defoct when in flesh, and in such cases it is only necessary to let them wear a boot until they have had time enough to become fresh. Wherever horses "go close," care should be taken that the shoes do not project beyond the hoof, and the clenches of the nails should be carefully watched, the owner seeing that they are filed down by the smith if they stand up at all above the level of the horn. Cutting may take place either on the prominent part of the fetlock-joint, or midway between it and the knee, or just below the "atter, which is called "speedy cutting," and is very apt to cause a fall. A boot should be fitted to the leg in either case, and worn till the part is thoroughly healed and all swelling has disappeared, when, if any likely method of treatment has been adopted the horse may be tried without it, but no journey should be undertaken without one in the pocket in case it may be needed. A peculiar method of shoeing, called a featber-edged shoe, will often prevent this bad habit as long it is adopted.

Stumburxg is vexatious enough, even in a plough horse, but in a roadster, and much more in a saddlo horse, it becomes a very troublesome anil dangerous vice. Its causes are very numerous, and these should be looked for carefully in each particular case before anything is attempted in the way of a cure, of which, indeed there is very little hope if the habit is at all confirmed. If in riding or driving a new horse you notice that he trips, erer so slightly, and then suddenly springs forward, you may be sure that the trick is an old one, and that he expects the righteous judgment of the whip or spur. If it arises from laziness or from a bad formation of the horse, as a too heary forehand or the forelegs being too much under the horse, there is very little hope for any improvement, though lazy horses will go safer at a fast rate than at a slow one. Any stumbler is worse at some time than at others, and on rough ground than on smooth. The vice is apt to show 
itself in travelling slowly up a gentle but stony rise. Old age and defective sight will make stumblers out of anything, and for theso thore can be little done. Such horses should be ridden or driven with a tight rein and a hand always realy to recover and lift them uip, but they are always unsafe. Bad feet, lameness, upright pastorns, overwork and leg weariness, are all causes of stumbling, and some of them can be provided for. Bad shoeing is a very prolitic source of this rico and in some such cases the reverse will effect a cure. If, however, a horse has once began to stumble, his best use thereafter will be in slow and heavy work or to loan as a saddle horse to men against whom you have a grudge. Consider your own neck too precious to ride such a horse if you can help it.

BALKiNG, or an obstinato refusal to work, is almost invariably the result of bad training or bad management. It is a suilky vice, and is very hard to deal with. Cruelty will often overcome it temporarily, and there are numberless methols of applying such a degree of torment that the poor brute will strain himself to almost any exertion rather than bear it, but the "sulks" are only overcomo for the time being and will return at the first opportunity. It is true that many horses are so completely ruined in this respect that nothing but pain seems to do any good, but even with them it really only confirms the evil. At all events we have no suggestions to make in the art of inflicting punishment, for earbiting, whipping, tail twisting, aud other gentle and merciful appliances are only too commonly well known. Gentleness, patience and firmness, will do best where anything whatever can be done. Many willing workers will sometimes balk when overloaded or overtired, or when their shoulders are out of order. In such cases cncouragement and help are the best modicines. A rrenerous horse will learn to start again very willing!y when ho finds his master seeming to pull or push with him., If a horse whose body and limbs are in good condition is an habitual balker, there is nothing to be done with him, he is incurably vicious and unsound.

Bachixg in harness is rery nearly allied to balking, and is caused partly in the same way, except that it is more temper and less sulkiness. Defective training, putting a colt to too hard a strain on the collar at first, or pushing him up hill bofore he has leained to pull: working a horse at any age with a sore or tentler shoulder, or giving him a load beyond his power, will teach him 
to back rather than tug. The remarks of Youatt on these two aro so full of good sense that we borrow them :

"One of the first species of restiffness, taking them in alphabetical order, is BACKIng or GibBirg. These are so closely allied, that we hardly know how to separate them. Some horses have the habit of backing at first starting, and that more from playfulness than desire of mischief. A moderate application of the whip will usually be effectual. Others, even at starting; exhibit considerable obstinacy and viciousness. This is frequently the effect of bad breaking. Either the shoulder of the horse had been wrung when he was first put to the collar, or he had been foolishly accustomed to start in the break up-hill, and, therefore, all his work coming upon him at once, when it being much more difficult to draw the break up-hill, than to back and let it run down-hill, he gradually acquired this dangerous habit.

"A hasty and passionate breaker will often make a really goodtempeted young horse an inveterate gibber. Every young horse is at first shy of the collar. If he be too quickly forced to it, he will probably take a dislike to it, that will occasionally show itself in the form of gibbing, as long as he lives. The judicious horse. breaker will resort to no severity, even if the colt should go out several times without touching collar. The example of his companion will ultimately induce him to take to it voluntary and effectually.

"A large and heary stone should be put behind the wheel before starting, when the horse, finding it more difficult to back than to go forward, will gradually forget this unpleasant trick. It will likewise be of advantage, as often as it can be managed, so to start that the horse shall have to back up-hill. The difficulty of accomplishing this will soon make him readily go forward at once. A little coaxing, or leading, or moderate flagellation, will assist in accomplishing the cure.

"When, however, a liorse, thinking that he has had enough of work or has been improperly checked or corrected, or beginning to feel the painful pressure of the collar, swerves, and gibs, and backs, it is a more serious matter. Persuasion should here first be tried; and, afterwards reasonable coercion, but no cruelty; for the brutality which is often exercised in attempting to compel a gibbing horse to throw himself habitually into the collar, never yet 
accomplished the purpose. The horse may, perhaps, bo whipped into motion, but if has once begun to gib, he will have recourse to it again whenever any circumstance displeases or annoys him; and the habit will be rapidly, and so completely formed, that he will become insensible to all severity.

"It is useless and most dangerous to contend with a horse determined to back, unless there is plenty of room, and, by tight reining, the driver can make him back in the precise direction he wishes, and especially up-hill. Such a horse should be immediately sold, or turned over to some other work. In a stage coach as a wheeler, and particularly as the near wheeler, or, in the middle of a team at agricultural work, he may be serviceable. It will be useless for him to attempt to gib there, for he will be dragged along by his companions whether he will or no; and finding the inutility of resistance, he will soon be induced to work as well as any horse in the team. This reformation will last while he is thus cmployed, but, like restiffuess generally, it will be delusive when the horse returns to his former occupation. The disposition to annoy will very soon follow the power to do it. Some instances of complete reformation have occurred, wut they have been rare.

When a horse, not often accustomed to gib, betrays a reluctance to work, or a determination not to work, common sense and humanity will demand that some consideration should be taken, before measures of severity be resorted to. The horse may be taxed beyond his power. He soon discovers whether this is the case, and by refusing to proceed, tells his driver that it is so; and the utmost cruelty will not induce many horses to make the slightest effort, when they are conscious that their strength is inadequate to the task. Sometimes the withers are wrung, and the shoulders sadly galled; and the pain, which is intense on level ground and with fair draught, becomes insupportable when he tugs up a steep acclivity. These things should be examined into, ant, if possible, rectified; for, under such circumstances, cruelty might produce obstinacy and vice, but not willing obedience.

Those who are accustomed to horses know what scemingly trivial circumstances occasionally produce this vice. A horso whose shoulders are raw, or that have frequently been so, will not start with a cold collar. When the collar has accuired the warmth of the parts on which it presses, the animal will go without reluctance. 
Some determined gibbers have been reformed by constantly wearing a false collar, or strip of cloth around the shoullers, so that the coldness of the usual collar should nerer be felt; and others lave been cured of gibbing by keeping the collar on night and day, although the animal is not able to lie down so completely at full length, which the tired horse is always glad to do. When a horse gibs, not at starting, but while doing his work, it has sometimes been useful to line the collars with cloth instead of leather ; the perspiration is readily absorbed, the substance which presses on the shoulders is softer, and it may be far more accurately eased off at a tender place.

Shoulder straps and collars are frequently lined with sheep-skin, the woolly side outward, and much ease has been afforded tho animal by this contrivance, especially where the harness has been indifferently fitted, or bccome hardened for want of greasing. 


\section{CHAPTER FIFTEENTH.}

\section{DISEASES OF IIORSES.}

Bone 'diseases-Classifiention-Splints-Ringbone-Sparin-Fistula of the withers-Poll-evil-Uleer of the jaw-Bighead-Fracture.

AND now wo come to the consideration of a most complicated subject, concerning which a vast amount of nonsense has accumulitted. Nor can wo attempt such a medical treatiso as will dispense with tho serrices of the vetcrinary surgeon. A man who is conscious of ignorance and inexperienco had better do as little in the doctoring line as may be, for horses, like men, will do best, on an average, with rery little medicine. An ounce of prevention, in the various ways which we have pointed out, is worth several hundred weiglit of attempted cure. As a rule, " nursing " and rest are of more value than anything else, and it may be set down guite positively that "if you are not sure what should be done you harl bettor not do it." On an arerage, a man will stand a good real more of random poisoning than a horse will, though it is astonishing low some will recover at the same time from the effects of discase and quackery.

In the frontispieco at lise berinning of this book, vie hare given a somowhat exagrerated representation of the extemal signs of many of the ills thet horsenesh is heir to, and in our hints on buying we have tried to describs the more common of them, but all riscases are not to be looked for on the surface. Many of them a:e the temporary consequencos of harl usage, bad fecting, harl st zbling, or accidents, and in any case the cruse must he sought for lefore any clear idea can be formed as to the most desirable treatment.

lire shall be compelled to be more or less technical, but will tiy and anake the matter as clear as possible, so that no no neod bo Ied astray by unaccustomed phraseology.

Discisfs of tile Boxe are rarely attended by any general symptoms, and in treating them it is only necessaly to care for tho 
gencral health of the "animal, as they are purely local in their" nature. Those of them which may be classed as " malignant" are incurable, and no space need be wasted upon them.

All bone diseases may be classed under the following heads: First, Exostosis, or superfluous growth of bone. Second, Caries, or ulceration. Third, Anchylosis, or the unnatural union of two bones, in consequence of either or both of the other diseases. Fourth, Fractures.

Exostosis is peculiarly a disease of joung horses, and rarely occurs after six or seven years of age, except in cases where it has become chronic. It is caused by superabundant nutrition of the part: that is, nature is too active and supplies more bony matter than the wants of the structure call for. It is to be detected in recent cases by a slight swelling of the part, accompanied by soreness. Sometimes it will be so located that no swelling appears to the eje, or can be found by the finger, and its presence is only indicated by lameness or tenderness. A severe blow on any bono that is only covered by skin may produce an inflammation followed by exostosis. This is a too active effort of nature to repair the injury. Orerwork will stimulate a precisely similiar over supply.

The most common exhibitions of exostosis are Splints, Ringbone,

- Snprin, and their lindred affections. In describing these and their trcatment we must acknowledge our indebtedness to the English work of M.Ir. J. H. Walsch, F. R. C. S. ("Stonehenge "), a very gond reprint of which has appeared in this country. Of course_no "green land" will have the presumption to altempt the moro diflicult experiments which he suggests, but, on the whole, his vicws and indications may be accepted as sound and sensible. Ho says of.

\section{SPLINTS.}

"The strict definition of this disease is ' an exostosis from the Iorrer part of the small metacarpal bone, connecting it by bony union with the large metacarpal bone,' but among horsemen, any bony growth from the cannon bone is considered a splint, and tho latter is almost as common as the former. The regular splint rarely attacks the outer small metacarpal hone alone, but somictimes in very bad cases both are implicated in the disease. It is dinicult to give a valid reason for this greater frequency of splint on the inside than on the out, but it is commonly said that the 
inner splint bone receires more of the weight of the body than the outer one, and that it is more under the ceutre of gravity, but as it is merely suspended from the carpus, and is not supported from below (in any way, mediately or directly), this can produce no injurious effect upon it. The fact is so, however, whatever may be the cause.

"The symptoms of splint are generally a greater or less degree of lameness during its formation, but sometimes it may go on to attain a large size without any such result, especially if its growth is slow, and the horse is not severely worked. It is commonly remarked that a splint is of no consequence unless its situation is such as to interfero with the back sinews, or suspensory ligament, and although it is quite true, as has been asserted by learned veterinarians, that the splint is far removed from the former, and seldom interferes with the latter, yet it is almost always directly connected with the attachments of the sheath of the tendon, and this being stretched every time the leg is extended will occasion the pain which is expressed by the limp in the action. . The size of the morbid growth has no relation with the amount, or even with the existence of lameness, for a very small splint will often be far more productive of this symptom than a very large one. In examining a leg it is often only after careful manipulation in the flexed condition that a small bony tumor (of the size perhaps only of a garden pea) can be detected, but when once the finger presses upon it, the horse will almost invariably be found to flinch, and usually it will be thrown out just where the sheath of the tendon is attached. Here there is no union between the large and small metacarpal bones, and the injury is confined to the inflammation produced in the sheath, which will generally go off after proper treatment and rest. These small bony growths are not very uncommonly met with in the hindlegs, but they are not reconnized there as splints. No constitutional symptoms are met with in these cases, and they must be ascertained by the local symptoms alone. Unless the splint is in the way of the action of the other foot, and the skin on its surface is bruised by repeated blows, there is seldom any swelling of the soft parts, but when this occurs, the skin and cellular membrane become puffed and hot, and extreme lameuess is the result, temporarily aggravated by every blow.

"The treatment of a splint will depend upon tho stato in which it exists, and upon the purpose to which the horse possessing it is 
destined. If no lameness exists, and the blemish is not oljected to, it is far better not to meddle with it, for in the course of a few years it will disappear by absorption as a matter of course. Moreover, it often happens that in attempting to remove a splint by some irritating application, extensive inflammation is set up in the fibrous strictures attached to it, and lameness; which was not previously in existence, is thenceforth a most troublesome attendant. If, however, the horse is to be sold, in which case the existence of a splint would be regarded with suspicion, or if lamcness has shown itself, it will be necessary to adopt measures likely to effect the absorption of the morbid growth, and these are chiefly two:-1st, Sub-cutaneous scarification, with or without a scton, or the seton alone; and $2 d$, Counter-irritation by means of some form of blister. If the soft parts covering the splint are much inflamed, the horse should have his corn taken away, and a dose of physic given him, during which a wet bandage should be lsept constantly applied, and indeed, in any case of splint severe enourro to require operation, the cooling remedies mentioned above should be adopted beforehand. The operation is performed with a probepointed narrow lnife, shaped like a scimetar, with the cutting edgo on the convex side. A small opening is made in the skin about an inch below the splint, and just large enough to admit the linife, which is then introduced and pushed upwards with its flat sido towards the skin, till it reaches the tumor, when the convex edge is turned towards this, and several extensive scarifications are madó in the periosteum covering it, after which the knife is withdrawn and a fine seton-needle is introduced in its place, and passed upwards until it reaches above the splint, when it is pushed through, and the tape drawn out, and properly secured with a bandage. Of course the horse must be cast and properly secured before resorting to the knife. In the course of ten clays or a fortnight the tape may be withdrawn, and the splint will almost invariably disappear. Sometimes the seton is tried without the scarification, but it is not nearly so successful, and is nearly as troublesome an operation. In most cases both of theso operations are unnecessary, and the application of the following blister (which has a tendency to produce absorption, independently of its counter irritative powers) will have the desired effect.

$$
\begin{aligned}
& \text { Tulse of Biniortide of MIcrcury . . . . } 1 \text { drachm } \\
& \text { Inul . . . . . . . . . } 1 \text { onnce. Mris. }
\end{aligned}
$$


And after cutting the hair short, rub a little into the skin, corering the splint, every night, until a free watery discharge is produced from the surface. To facilitate this the leg should be fomented with very hot water every morning and aftemoon, and this should 3) continued for several days after the ointment has been discontinued. The horse will not gnaw the stin after this application, and it is a very useful one for general purposes, when counter-irritation is required to produce absorption. If after a week's interval, the splint does not appear much reduced in size, the ointment should be re-applied, and repeated at similar intervals till the swelling is removed. When the bony growth is very extensive, neither scarification nor counter-irritation will be of much serrice, and the leg must be fired, and afterwards repeatedly blistered, but even with the best and most energetic treatment, the part will seldom become sufficiently sound to stand anything but slow work.

\section{RINGBONE AND SIDEBONE.}

" Ringbone and sidebone both consist in the throwing out of bony matter about the joints of the os coronæ; the former name being given to the disease when it attacks that between it and the os suffraginis, and the latter when the seat is the parts around its union with the os pedis or coflin-bone. Very often, and especially in heary cart or dray horses, ringbone and sidebone co-exist in the same leg where the three bones are completely anchylosed, and in which, during life, the only action was in the fetlock joint. The disease attacks the hindleg as well as the foro; but it is moro common in the latter than in the former.

"The symptoms are a greater or less enlargement of the leg, of a hard or unyieiding nature, either immoliately above the coronet, as in sidebone, or a littlo higher, as in ringbone. In the latter case, if thoroughly established, it surrounds the joint, whence tho name of ringbone; but in the early stages it appears at ccrtain points from which it spreads all arount. Sidebone is seldom so extensive and usually attacks the postero-lateral parts of the os corone, where the swelling is denfuel, and, except in very lairylarged or gummy-heoled horses, can easily be felt. In the early stages the action is not impeded, but there is more or less soreness or lameness. After much bone is throrm out, the joints are either completely fixed or their movements are extremely limited. 
"The treatment in the early stage is precisely similar to that for splint; but the operation of scarifying the periosteum requires great care and some knowledge of the anatomy of these joints, or the knife will pierce the capsular ligament, and increase the evil it was intended to relieve. A seton without the scarification will often be of service, and for sidebone, fring in the early stage will be serviceable, though it is objectionable on account of the blemish it leaves behind. The biniodide of mercury ointment already described is most useful in slight cases, but in severe ones it will rather tend to aggravate the growth, and when anchylosis has taken place, nothing but time and patience for the subsidence of the inflammation will avail. When this has taken place, and the joint is fixed, a high-heeled shoo will enable the horse to work, with some awkwardness, it is true, and the addition of a leather sole will to some extent take off the jar, which occurs in a greatly increased ratio when the elastic action of the pastern-joints is destroyed.

\section{OSSIFICATION OF TIE IATERAL CARTILAGES.}

"This is commonly known as ossification of the cartilages, $\mathrm{Or}$ false ringbone, no other cartilages being subject to ossification, and these being therefore known par excllence as the cartilages. In heavy cart horses it often co-exists with ringbone and sidebone, especially the latter; but it also attacks well-bred carriage-horses, and high-actioned hacks, which are comparatively free from those diseases.

"The symptoms are more or less enlargement of the back of the coronet, and heel, the part feeling unnaturally hard and irregular or lumpy. If recent, there is generally increased heat on careful examination with the hand; but in old standing cases there is nothing of the lzind to be detected. Lameness is not always present, but if the horse is rattled over hard ground, he will bo more likely to show the effects on the next day, by going short and sore, than if he were free from this disease.

"The treatment should be confined to recent cases, for in old standing ones, unless lameness shows itself, it is better to aroid any interference. A seton, with rest, has sometimes proved very efficacious, even in confirmed ossification, and repeated dressings with biniodide of mercury ointment, will, in those cases where the 
inflammation does not run very high, afford the best chance of causing the absorption of some of the bone, for a complete cure is nerer effected. When there is much heat in the part, bleeding from the foot may be adopted, and afterwards the application of cloths dipped in cold water, with the addition of a glass of tincturo of arnica to a quart of water. In confirmed cases, where the parts have become callous, a leather sole to the shoe will take off the vibration, and should be used during the summer season. Scarification of the skin covering the enlargement with a lancet, encouraging tho bleeding by warm water, and followed by tho use of cold water as soon as the bleeding has ceased, will sometimes do wonders in recent cases. The scarification should be? repeated at intervals of five or six days, taking care to avoid injury to the coronary substance near the hoofs, which is sometimes followed by troublesome sores.

\section{BONE SPAVIN.}

"This disease, so frequently the cause of lameness in thoso horses which use their hocks severely (as for example, race-horses, hunters, carriage-horses, and more particularly cart-horses), consists in exostosis fiom the adjacent external surfaces of the tarsal bones, always showing itsolf at the inner sicle of the hock-joint, on the scaphoid and cuneiform bones, and extending to the head of the internal small metatarsal bone. As in the case of splint, tho occurrence of exostosis on the internal rather than on the external sile of the hock has been accounted for by the supposition that increased weight is thrown upon the inteinal small metatarsal bone, fiom the turning un of the outer heel of the shoe, which is the c)mmon practice of smiths. It appears to me, however, that the contrary is the case, and that though more stress is laid upon the foot on that side, there is less weight on the inner side of the hock, which has a tendency to spring open in that direction. This will cause a strain upon the ligaments connecting the tarsal bones, and inture coming to thicir ạid tinrows out bone, which ultimately sul)stitutes ancliylosis for ligamentous union lsetween these bones. In all the actions of the hindleg, from the natural shape of the hock, and more especially in those linrses which are naturaily "cowhocked," there is a tendeney to yield inwarils rather than in the opposite direction. The consequence is that there is more strain 
upon the ligamentous fibres which connect the scaphoid with the two cunciform and the internal metatarsal, than upon those uniting the cuboid with the os calcis and external metatarsal bone. Hence, although exostosis does sometimes show itself in other parts of the tarsal bones, it here, as in the foreleg, is almost always confined to what is called the "spavin place," namely, the contiguous surfaces of the scaphoid, cunciform, and internal metatarsal bones. In rery bad cases the articular cartilage becomes involved, and there is not only an external casing of new bone, but the internal surfaces absolutely coalesce or anchylose.

"The symptoms of sparin are a hard substance showing itself beyond the proper level of the hock-joint. There may or may not be lameness, but if bone is thrown out the disease is established. In recent cases whenever the horse is worked he will, ffer rest, limp in his action, but the lameness soon gces off, and does not show itself agran until the part has been suffered to become stiff by a rest of an hour or two. The lameness is very remarkable, and differs greatiy from that shown in any other disease. The leg is drawn up with a quick catch, and yet there is a dragging of the limb, indicating not only pain in the joint, bul a want of action in it. In the early stages the latter is not clearly developed, but afterwards it is so well marised that a spavin may be pronounced to exist without an examination of the joint. Where lameness is not establishel, gront caro should be exercised in pronouncing on the exictence of sparin, for some hocks are naturally formed with prominent heads of the intemal metatarsal bones, and the incxperienced eye and land are very apt to mistake these for exostosis. In such cases, by émparing the two hocks it will generally bz seen that thes are both exactly alike, while in spavin, although both joints may be the seat of mischief, yet they will selilom manifest the disease to the same extent.

"The tratmont should be directed to the abatement of the inflammation which gives rise to the pain, and also to promote absorption of the new growth. Teterinary surgeons are very apt to assert that the disease cannot be cured, and that a sparined lorso will always remain the suhject of it, and therefore unsound. But practicaliy it is known that many a hock which has been the seat of undoubted spavin loses all external enlargment, and no limeness is shown in it, although tried most severely through a series of 
years. Still on dissection after death, the ligaments will not show thei: natural white and glistening structure, and the tarsal bones will be to a certain extent united by anchylosis In very hat cases thers will be also caries of the articulatory surfaces, and with it inflammation of the synovial membranes, which may and often does exists without the caries. Now as these are much more formillable diseases than exostusis, and far more difficult either to cure or palliate, it follows that although certain remedies will be gonerally successful with genume bone spavin (exostosis), yet they will fail when the above complication exists. The treatment must therefore be adapted to the exact nature and cxtent of the discase. Prior to the adoption of any plan the joint should be rested, the outer heel of the shoe should be lowered, the corn should be taken away, and the system cooled by appropriato treatment. After these precautions are taken, the next thing is to decide upon the remedies which will bo suited to the case. They consist in-1, Blisters, which have a tendency to cause absorption; 2, Firing; 3 , Setons, with or without subcutancous scarification; 4, Division of the nerre. If there is simply a slight exostosis, with little lameness, and no evidence of the joint being implicated, the biniodide of mercury may be applied as described at page 108. Repeated dressings will be necessary, and the joint must have at least two months' absolute rest, the horse being placed in a loose box. This remedy is often successful, but it will fail utterly where the exostosis is extensive, or there is caries, or even serere inflammation of the synovial membrane. Arsenic, sulphuric acirl, and other caustic applications, have been counted as infallible cures; but while they are just as certain to produce a blemish as firing, the extent to which the inflammation and sloughing, caused by them, go, is far more completely beyond our control. Arsenic lias been known to destroy the joint, ly producines a slough of the synovial membrane, and it is said that the sulpluric acid, which, however, is often very successful, has had a similar unfortunate result; but of its being followed by serious blemishes there is abundant juroof. Firing is the safest and, therefore, the usual plan adopted for spavin, and on the first intimation of the disease it is often adopted without any necessity for having recourse to so disfiguring a process. Its chief advantage is, that while it is a certain means of establishing a strong counter-irritation, it has no tendency to cause any increase 
of inflammation in the structures beneath the skin, and therefore the good it does is unalloyed by any counterbalancing evil. It is now the fashion to deny its use, and horsemasters are often tempted in try some substitute for it, in the hope of escaping a blemish; but $(\cdots)$ often they are compelled to submit to it at last, and proin., w after the disease has been agravated by some " unfailing" remedy. If there is a strong desire expressed to aroid a blemish, the reterinary surgeon is perfectly warranted in doing all in his power to effect a cure without the use of the irons; but the mero fashion of the day should not induce him to decry a plan which has for so many years been proved to be successful. In luman surgery the same course has been adopted, and for the last thirty or forty years the actual cautery has been roted "barbarous" in this country. Now, however, a counter current is setting in, and it is the general opinion of the first hospital surgeons of the day that, in certain diseases of the joints, no remedy is nearly so efficacious. All sorts of attempts are made to render the use of the hot iron less repugnant to the senses; but in the case of the horse it is only necessary to measure its comparative utility and tho amount of pain which it gives. The former has been already considered, and as to the latter, if the irons are properly heated, I much doubt whether their action is not less painful than that of any other counter-irritant. Setons, perhaps, give less pain if skillfully inserted, and they are admirable remedies, haring nearly the samo beneficial effects as firing, and leaving a far slighter blemish. They should be passed beneath a considerable track of the skin, covering the "spavin place," and the tape requires to be smeared with blistering cerate to produce sufficient irritationTheir use by themselves is often sufficient, but when preçeded by subcutaneous scarification they seem to act even more certainly than firing.

"The method of operation is similar to that described for splints, but it requires more knowledge of the anatomy of the parts to aroid doing mischief by cutting into one of the joints. There is always afterwards considerable effusion into the subcutaneous collular membrane, demanding two or three months for its removal ;

- but as the spavined horse requires that interval of rest, this is of little or no consequence. When the disease has gone so far that no method of treatment will remove it, the nerve above the hock may 
be divider, which will enalile the horse to work without pain for a time, but the disease goes on the faster, and the benefit derived is only temporary.

\section{EXOSTOSIS OF THE HUMERUS AND SCAPULA.}

"The heads of the bones adjacent to most of the joints of the body are more or less subject to exostosis, though not so frequently as those of the pastern bones and tarsus. Next to these probally comes the shoulder joint, the neighborhood of which is often the seat of this disease. The left seapula and humerus of a horse are often completely anchylosed, and of course there co-exists a proportionate amount of lameness during the progress of the disease, while after the anchylosis talies place the want of action is complete. An examination by the hand of the point of the shoulder would readily detect so large a growth of bone as this; but smaller ores are often thrown out beneath the mass of muscles surrounding the shoulder joint, and consequently beyond the reach of the most accomplished finger. The treatment should be on the same principle as for spavin, omitting the subcutaneous scarification, which is not here practicable on account of the nature of the joint. Blisters, and especially with the biniodide of mercury, will be the most likely to succeed. but in most cases the cure will be only partial."

A disease much less common in the United States than in England, for the reason that horses are employed to a less extent under the saddle, is that which is known as "thiselo," which is a vulgar corruption of "FrsturA of the withers." It is caused by blows, pressure or other mechanical sources of inflammation. The first symptoms are heat and tenderness, accompanied by a slight swelling, and at this point perfect rest with warm fomentations will frequently check the difficulty. This, however, does not often happen, as-the symptoms are likely to be unnoticed or disregarded until an abscess has begun to form, and this may be detected by the fluctuating feeling when lightly pressed by the finger. No timo should be lost, and an opening should be made low down on the right side, so low that there is no part of the "sack" of the abscess below it to retain any of the poisonous matter, and large enough to let, the matter all run out as fast as it forms, for "fistula" is in a measure self projergating, and the secretion is not only 
an effect, but a cause of the inflammation. Entire relief from it, with rest, will sometimes be sufficienl to work a cure without special applications. In cases of long stauding, however, the "sack" itself and the passage leading to it lecome lined with a tough membrane, and nature is prevented from doing her work. In such cases a seton tape, passed through from end to end and left there, or an injection, will be of service. The latter may be one of several very good prescriptions. As good as any is one drachm of chloride of zinc dissolved in a pint of water, and carefully injected into every part of the "thiselo" two or three times a week.

A disease very similar to fistula, in cause, effect and treatment, is Poxis Evil. It may be brought on by a blow on the top of the head, or the animal "bumping" against his manger or his stable door, or by a too great strain caused by tight reining, or otherwise. The ligament of the neck passes over the "atlas" or first bone of the neck, without being attached to it, and the seat of the inflammation is between this ligament and the bone beneath. It will readily be seen what intense pain would be caused by the formation of matter at such a point if no way for its escape should bo provided.

The treatment is simple, almost identical with that for fistula, only great care must be taken to aroid the spinal cord, the knife should not be run in deeply, but slantingly, and on the right side, making a passage that will surely permit all the pus to run out. A seton should generally be employed. If the opening is made with the needle, put it in on the top of the swelling, make sure that it reaches the bottom, and bring it out a little below the abscess on the right side. The reason for this latter is that most horses lie down on the right side, and thus, both in fistuia and poll-evil the matter can continue running when he is lying down. If he happens to have formed the habit of laying on his left side, act accordingly.

Very bad cases of either of the two last mentioned diseases require severer treatment, and such nianipulation and surgery as can hardly be successfully attempted by inexperienced hands.

ULCERS on the jaw (carics) may be caused in various ways, perhaps more frequently by cruel and barbarous bits than in any other. Hard pullers and vicious lorses are likely in this way to suffer the reward of their ill doings and bad temper. 
The symptoms are a tendency to blecel at the inntil from a slight pressure of the bit, and an appearance of jirk froth. In such a caso a furthor examination may liscover a peculiar sore ; it may be on either the upper or lower jaw, or on the roof of the mouth. There will be a depression, indieating loss of substance, and containing more or less of prout flesh, clearly an umnatural growth, and but slightly attached to the sides of the carity. Thero is a continual discharge, ofrensive and watery, but this is generaliy lost in the horse's saliva.

The treatiment is simple but effectire. Take away the bit that caused the difficulty, ant, if the horse must be used, cmploy a lit that will press elsewhere and be milder in its operation. Keep) the wound open by the use of lunar caustic. Press the caustic in hard and quick, not letling it burn over two seconds, and not any more than is necessary to keep down the proud flesh. By keeping up this treatment patiently the disease can in time be pretty effectually cured.

In the northern and eastern parts of the United States we havo very little of what is known as the BIG IIEAD among horses, though as much can hardly be said for their owners. In the South, West and Surihi-West, this discase (nstco streomic) is more common. It is a malignarit growtin fron the collulai stucture of the jaws, and partakes both of the nature of bone and cartilage. The symptoms are altogether local, and cannot well be mistaken. Any largr, irregularly hard, unwieldy swelling on either of the jaws may be set down to this clisease. It is a terrible thing, not unfrequently growing in such an eccentric way that the ponr animal camot shut his mouth, and dies of starvation. Its arlvance is slow but sure, and there is nothing to be done for it. It has, in some cases, heen removed by amputation, but the swelling and the horse were gencrally destroyed at about the same time. If your horse has the "ligig head," work him as long as you can with humanity, ant then humanely shoot him.

it is a generally receired notion that when a horse has fractureil a bone it is all up with him, ant he must be clestruyed. This is practically true, in most cases, and yet many are on record in which such injuries were treated with a rery fair degree of success. The difficulty lics not so much in the refusal of broken lones to wite, as in the skill and appliances required to keep the parts 
which are to be rejoined "in position," the animal himself being apt to add his own obstinato strugglos to the other bad features of his misfortune. At all events, a higher degree of surgical skill must be called into play than is apt to fall to the lot of those for whom we are writing, and we can only advise them to take the best local advice they can get, promising that it will be, almost invariably, "Kill him." 


\section{CHAPTER SIXTEENTH.}

\section{DISEASES OF HORSES.}

The joints, muscles and tendons-Rheumatic inflammation-Bog-spavinThoroughpin-Windgalls-Capped hock-Strain of back sinews-Strain of shoulder, lnee, fetlock and cutfin-bone-Breakin's down-Strains of hip-joint, stille and hock-Curb-Dislucation-Wounds of joints.

IN attempting to deal with this class of horse-evils, and it is a very important one, we are confronted by a good deal of apparent difficulty in being clear and çoncise without being technical. The meaning of some terms will be best acquired by a study of the cuts, while for others the entirely inexperienced must bo referred to the dictiona, y.

Muscle is subject to simple atrophy, with or without fatty degeneration. The disease shows itself by a wasting away of tho part, accompanied by a flabby feel to the touch. It should be lieated by friction, gentle but regular work, and steel given internally, one drachm of the sulphate of iron, powdered, being mixed with the corn twice a day.

Rinematic inflamination of a muscle or muscles is one of tho most common of all the diseases to which the horse is subject. Most frequentiy it attacks the muscles of the shoulder, or of the loins, sometimes both those parts being involved at the same time. When acute it receives the namo of a chill, and is generally brought on by exposing the horse to a draught of air after work, or by immersing him in cold water up to his belly, with a riew either to refresh him, or when the groom is lazy, to save him the trouble of cleaning. The symptoms are lameness or inability to use the part, the horse, when forced to do sc, giving expressions of severe pain. If the shoulder is affected, the foot is not put to the grounl, and when the leg is mored backwards and forwards by the hand, great pain is evidently experiencel. In severe cases there is fever with accelerated pulse (70 to 80), accompanied often by profuse sweating, and heaving at thic flanks, the legs remaining warm. 
After a short time the part swells and is excessively tender. The treatment should be by a copious bleeding, if the horse is of a moderately strong constilution; indeed, in severe cases, it should be carried on till the pulse is greatly reduced, and repeated the next day, if it returns to its original hardness and fulness. The bowels should be acted on as soon as it is safe to do so, and if the dung is very hard, backraking and clysters should be used, to accelerate the action of the medicine. The best aperient is castor oil, of which a pint may be given with an ounce of sweet spirits of nitue. When this has acted, if the kidneys are not doing their duty, a quarter of an ounce of nitre and a drachm of camplior may be made into a ball and given twice a day.

Chrovic RHEUMatisu of the muscles is similar in its nature to the acute form, but, as its name implies, it is more lasting, and of lcss severity. It often flies from one part to another, attacking the ligaments and tendons, as weil as the muscular fibres. It is seldom much under control, and attention should be praid rather to improve the general health than to subdue the local affection.

SMALL Trors, of about the size of a pea, often form upon the tendons, especially the "back sinews" of the forelegrs. They may or may not occasion lameness, but they are always to be regarded with suspicion. As long as they remain indolent they are better left alone; but when they produce inflammation and pain, the best reniedy is the biniodide of mercury ointment.

Uleeration of the cartilage is by no meaus common in the horse, and when it occurs it is generally complicated with other difficulties. No general rulẹs can, therefore, be given for its treatment.

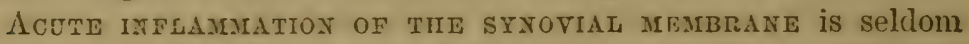
met with: but a chronic state, inlucing an excessive secretion of synoria, is extremely common. The most usual situation is at the lock, where the swelling has received the name of bog-spavin and thoroughpin; but they also occur at the fetlock and knee joints; in tho former case being sometimes confounded with windgalls, which are inflamed burse mucosa (mucous sacks).

BoG-SPAVIN is very apt to attack young horses, when they are orer-worked, before boing fully seasoned; but it may occur at all ages. It shows itself at the inner side of the joint, because here the ligaments are wider apart, and there is more room for distension. Its seat is the capsule between the tibia and astragalus 
- Which is here unprotected ly any strong fibrous covering, and readily yieldis to the gradual pressure of the secretion from it: internal surface.

Thoroughrix may be efther an increased sceretion of the synovial capsule, between the astragralus and os calcis, or between the scaphoid and cuneiform bones, or of the bursa mucosa lying leetween the tendo Acliiles and the tendo perforatus. In the first of these cases, it often co-exists wit: borg-spavin, and the synovia may be made to fluctuate from one bag to the other, the only line of clemarcation being the astragalo-calcanean ligament.

Both bog-spavin and thoroughpin may exist, or either separately, without occasioning lameness ; but where tirey are just established there is generally some small degree of active inflammation, which causes a slight lameness on first going out of the stable, but soon disappearing.

The treatment should be by pressure, kent up for a long time, by means of a carefully-acljusted truss, altemated with cold bathing, and the use afterwards of tincture of arnica, diluted with water, as a wash. Subcutaneons scarification has succeecied in some few cases in causing the secretion to cense; but it has so often produced extensive inflammation of the joint, that the operation is by no means to be recommended. Ilistering with biniodide of mercury has also occasionally answered; but no plan is so successful, on the whole, as pressure, alternating with cold bathing.

Delicate young foals are subject to a rheumatic inflammation of their synovial membranes, specially displayed in the knees and hocks, and apparently caused by exposure to cold. It seldom goes on io produce disorganization of the cartilages, but the cạpsular ligaments are distended with thin yellow synoria, causing considerable stiffness. The cellular tissue around the joints also becomes oclematous, and the lerss fill all the way down to the feet. It is commonly known among breeder's as the "joint evil," and though in utself it is not dangerous, yet it marks the existence of constitutional weakness which is likely to occasion some more fatal malady. The treatmont should consist in attending to the general health by strengthening the mare, which is best done by giving her a drachm of the sulphate of iron in her corn twice a day. The joints of the foal should be rubbed with equal parts of soap liniment and spirit of turpentine, and it should be assisted to stand 
for the purpose of sucking at regular short intervals if unable to help itself. In aggravated cases, however, the foal is not likely 10 recover its general strength, and it may be better to destroy it, but so long as it can stand and feeds well, hopes may be entertained of the joints recovering.

Every practical horseman is aware that the sheaths in which the back sinews and other tendons are lodged are liable to inflammation and thickening, without the tendon itself being involved. By passing the hand down the leg, an irregular network may be felt surrounding the tendons, which move up and down without disturbing it; and the surrounding cellular membrane is also thickened, and becomes hard and unyielding. There may be considerable heat about the part, but often it is quite cool; and tho disease may continue for months without any great lameness, and with nothing to draw attention to it (excepting a slight stiffness on leaving the stable) but the sensation communicated to the hand. At length; an unusually hard day's work sets up active inflammation, the leg rapidly fills, and there is so much lameness as to cause the horse to be thrown by. The treatincnt, in the early stage, should be the use of bandages, constantly kept wet with arnica and water, and nothing but walking exercise. After the thickening is fully established, no remedy short of blistering, or a charge, will be of the slightest avail, with a rest of two or three months.

The synovial bags are liable to inflammation, either from hard work, as in windgalls and thoroughpin, or from blows, as in capped hock and elbow. The latter are said by some reterinarians to be serous abscesses; but there is no doubt that in all horses a mucous sack exists under the skin on the cap of the elbow and hock; and these become inflamed and filled with a very thin synovia, when they are bruised. They never extend beyond a certain size, and have no tendency to burst; nor are they inclined to a healthy termination of their own accord, but go on in the same condition from year to year.

WINDGALLS or puffs, are the most usual forms of these enlargements, and may be observed in the legs (hind as well as fore) of nearly every hard worked horse, after a time. Great care in the management of the legs. by bandaging will sometimes keep them off, and some horses have naturally no tendency to form them, but in most cases, on examining the legs, just above the fetlock 
jointe, of horses at work, a little oval bag may be felt on each side, between the back sinew and the bone. If recent, it is soft and puffy; but if the work is hard, and the windgall is of long standing, it will be as tense as a drum. The synovial bag has no communication with the fetlock-joint; but there is another sack in front of the joint, and beneath the tendons of the extensors, which is often enlarged, though not so much so as the seat of the truo windgall, and which is generally, though not always, continuous with the synorial capsule of the joint. The treatment consists in pressure by means of bandages, and the application of cold lotions, if the legs are hot and inflamed. Blistering and rest will remoro them entirely; but no sooner is the horso put to work again, than they return as badly as ever. There is no radical cure but subcutaneous puncture and scarification, and this will produce too much adhesion to be advantageously applied.

CAPPED HOCK is often the result of a bruise of the superficial fursa or sack, which is situated on the point of the hock, immediately beneath the skin. It indicates either that the possessor has kicked in the stable or in harness; but it is more frequently caused in the former way than in the latter. The swelling is sometimes slight, being then just sufficient to show the joint slightly enlarged, and to give a soft, puffy sensation to the fingers, where there ought to be nothing but bone felt beneath the skin. The bursa always rolls freely on the bone, and when large, it can be laid. hold of and shaken like a bladder of water. The treatment should be directed to abate any slight inflammation that may exist, if the case is established; but in recent ones, it is doubly necessary to apply cold lotions, which, however, there is some difficulty in doing, owing to the prominent nature of the part. A piece of stout calico or fino canvas may, however, be shaped into a cap, carefully fitting the point of the hock; and this being tied by several pieces of tape in front of the leg, will allow not only of the application of cold lotions, but of pressure also. By this plan, continued for some weeks, considerable enlargements havo been removed, but they aro very apt to return on the slightest bruise. Setons through the lursa, and injections into its cavity of stimulating applications havo often been tried; but they generally do more harm than good, and nothing can be relied on but the conjoint use of pressure and cold applications. The best lotion is the following:-- 


\section{Take of Tincture of Arnica . . . . 3 oz. ILuriate of Ammonia . . . . 2 " Methylated Spirit of Wine . . . 4 " Water . . . . . . . 3 pints. Mix.}

CAPPED ELBOW is precisely similar in its nature to capped hock, and must be treated in the same way. It is also known by the name of capulet.

The fibres of muscles, ligaments, and tendons, and the fascia covering them, are all liable to be overstretched, and more or less, mechanically injured. This is called a strain, the symptoms of which are similar to the inflammation of the part occurring idiopathically. They are heat, swelling, and pain on pressure, or morement, shown by flinching in the one case and lameness in the other. In some cases there is considerable effusion of blood or serum, the former occurring chiefly in the muscles, and the latter among the torn fibres of the tendons or ligaments. The symptoms and treatment will depend upon the part injured, which will bo found described under the following heads; but in most cases an embrocation composed of equal parts of laudanum, olive oil, spirit of turpentine, and hartshom will be beneficial if applied after tho first active inflammation has subsided.

When a young horse is urged to excessive exertion he is very apt to orer-exert himself in his awkward attempts to clear tho obstacle, and next day he will often show a stiffness of the loins and back, which is seated in the large muscles connecting the pelvis with the thorax. He is said to hare "ricked his back," in in the language of the stable, and if the mischief is confined to the muscles alone, he may generally be permanently cured, though he will be more liable to a return than an animal which has nerei sufiered from any accident of the kind. If, however, tho spinal cord is injured, either from fracture of the vertebræ, or from effusion of blood, or serum pressing upon it, the case is different, and a perfect cure is seldom obtained. It is, however, very difficult to distinguish between the one case and the other, and the treatment may generally be conducted with the hope that the moro important organ is uninjured. When there is complete palsy of the hind extremities, so that the horse can neither feel nor use them in the slightest degree, the case is hopeless. For the management of the strain of the loins, a full bleeding should be adopted, as it generally happens that the horse is plethoric and full of corn. 
Then apply a doulble fold of thick flannel or scige, dipped in warm water, to the whole surface of the loins, cover this over with a layer of india-rubber sheeting, ancl let it remain on, taking care to renew the water if it has become dry. It generally produces a copious sweating from the part, followed by a slight irritation of the sisin, both of which afford relief. In three or four days tho flannel may bo removed, and the embrocation alluded to above rubbed in two or three times a day, which will gencrally relievo the muscles so much that at the end of a week or ten days the horse is able to move quietly about in a loose box, and the cure may be left to time, aided by a charge on the back.

SHoulder straix was formerly very often chosen as the seat of lameness in the fore extremity, solely because the case is so obscure that it is beyond the knowledgo of the unskillful examiner. Nevertheless, it is by no means so uncommon, as is supposed by some writers, and perhaps it may be asserted that it is now more frequently passed over when it really exists, than the reverse. It may be seated in any of the muscles round the shoulder-joint. The symptoms are very peculiar, and cannot well be mistaken by a careful olserver who has once seen a case of shoulder lameness. In all other kinds (except the knee), the limb is freely mored while in the air, and no pain is expressed until the foot is about to touch the ground; but here the lamenoss is greatest while the knee is being protruded, and the limb is slung forward sideways, in a circular manner, which gives an expression of great imbecility. It also occasions great pain when the foot is lifted and drawn forward by the hand, just as in rheumatism of the part. When the strain is caused by a jump or a slip, causing the logs to be widely separated, there is often great obscurity in the case; but the history of the accident will generally assist in forming a correct diagnosis. The trcatmont in tho early stage will consist in bleeding from the plate vein, to the extent of five or six quarts of blood, followed by fomentations with hot water, if thero is much heat and swelling, and giving a dose of physic as soon as the bowels will bear it. When the heat has disappeareil, or at once, if there is none, apply the embrocation described at page 124; and if this does not produce reiief, add to it one-quarter of its bulk of tincture of cantharides.

THe KXEe, unlike its analogue in the human sulject (the wrist), 
is seldom strained in the horse, in consequence of the strong ligaments which bind the bones of the carpus together. Still it sometimes happens that the internal lateral ligaments are overstretched, or, in calf-lneed horses, the posterior common ligaments, or that connecting the scaphoid with the pisiform bone, or probably all these will suffer from orer-extension. The acident may be recognized by the heat and swelling of the part affected, as well as by the pain given on using the joint. The anterior ligaments aro seldom strained, but they are liable to injury from blows received in various ways. The trcatment should be conducted on the samo principles as those of strains in the shoulder. Cold applications will seldom do anything but harm in the early stage; but after hot fomentations have relieved the active mischief, by encouraging tho effusion of serum into the stirrounding cellular membrane, tho former may be used with advantage. When the heat and other signs of active inflammation have disappeared, the biniodide of mercury ointment may be rubbed in, aroiding the back of the joint.

STRAIN ON THE FETLOCK shows itself at once, in consequence of the superficial nature of the joint, by swelling, heat, soreness to the touch, and lameness. It may be very slight or very severe, but in the latter case it is generally complicated by strain of the back sinews, or suspensory ligament. The treatment will be precisely on the same plan as for strain of the knee. When the anterior ligaments of the fetlock joint are strained and inflamed, as so often happens with race-horses, the condition is known as "shin sore." - Dissection proves that the coffin-joint is sometimes the seat of strains; but it is almost impossible to ascertain its existence with certainty during life. The diagnosis is, however, not of much consequence, as the treatment will be the same, whether the coffinjoint, or the navicular-joint is the seat of the mischief. In any case, if severe, bleeding from the toe should be had recourse to, followed by cold applications around the coronet, by means of a strip of flannel or felt, tied loosely around the pastern, and kept constantly wet. When the heat has subsided the coronet should be blistered.

The-SUSPENSORY LIGAMENT not being elastic, like the back sinews (which, though not in themselves extensible, are the prolongations of muscles which have that property), is very liable to strains, especially in the liunter, and to a less degree in the 
race-horse. The acciclent is readily made out, for there is local swelling and tenderness, and in the well-bred horse, which is alono likely to meet with a strain of this kind, the leg is rarely suficiently gummy to prevent the finger from making out the condition of tho ligaments and tendons. There is no giving away of the joints as in "break down," but on the contrary the leg is fexed, and if the case is a bad one, the toe only is allowed to touch the ground. In ordinary cases, however, there is merely slight swelling of tho suspensory ligament in a limited spot usually near its bifurcation, or sometimes in one division only close abore the sesamoid bone to which it is attached. Tho horse can stand readily on that lerg, but on being trotted he limps a good deal. Sometimes, however, there is a sivelling of tho feet without lameness, but in this case the enlargement is generally due to an effusion of serum into the cellular covering of the ligament, and not to an actual strain of its fibres. The treatment will depend greatly upon the extent of the mischief; if there is no great injury done, and the enlargement is chielly from effusion of serum, rest and cold applications by means of bandages or otherwise will in the course of two or three months effect a cure. Generally, however, the case will last six or eight months before the ligament recovers its tone; and in a valuablo horse no attempt should be made to work him before that time. Where the swelling is small, as it generally is, bandages have no power over it, as the projection of the flexor tendons L.: pls tho pressure off the injured part. Here, dipping the leg in a bucket of water, every hour, will be of far more service than a bandage, and the sudden shock of the cold water will be doubly efficacious. After all heat has disappeared the biniodide of mercury may bo, used as a blister two or three times, and then the horse may either be turned out, or put into a loose box for three or four months, after which walking exercise will complete the cure.

In STRAIN OF THE BACK sINEWs the position of the leg is the same as in strain of the suspensory ligament, and there is no giring way af the joints. The flexor tendons are enlarged, hot and tender, and there is great lameness, the horse having the power to flex the joints below the knee, but resolutely objecting to extencl them, by bearing what little weight is unavoidable upon his toe. The case is often confounded with a "break down," but it may readily be distinguished by the fact that in the latter the joints 
give way on putting the weight upon them, whilst in mere strains they do not, and the tendency is to the opposite extreme. Frequently after a bad strain of the flexor tendons, the fetlock is " over-shot," or beyond the upright, in consequence of the contin. ued flexion of the joint, to prevent pressure upon the injured fibres, and in the management this result should be carefully guarded against. The injury is generally confined to the sheath of the tendons, which, in most cases, gradually puts on inflammatory condition for some time before actual iameness is observed. In bad cases, however, the ligamentous fibres which are given off by the posterior carpal ligament to the flezor tendons are ruptured, greatly increasing the amount of inflammation, and subsequent loss of strength. In any case the tendon feels spongy, and slightly enlaryed, and there is more or less soreness on pressure, and on being trotted, but in the latter case exercise removes the tenderness, and very often temporarily causes an absorption of the effused Aluid, which is again deposited during rest. This state of things goes on for a lime, the keeper doing all in his power to alleviate it by wet bandages, ete., but at last severe work brings on an amount of inflammation, with or without actual strain of the fibres of the tendon, and there can be no doubt about the propriety of rest and severe treatment. It often happens that both legs are slightly affected, but one being more tender than the other, the horse attempts to sare it by changing legs, the consequence of which is that the comparatively sound tendons are strained, and he returns to his stable with both legs in a bad state, but with one of them requiring immediate attention. The treatment should be by local bleeding (from the arm, thigh, or toe), followed at first by warm fomentations, and in a few days by cold lotions. A high-heeled shoe (called a patten) should be put on the foot, so as to allow the horse to rest part of the weight upon the heel without distressing the tendon, and this will have a tendency to prevent him from over.shooting at the fetlock-joint, which he will otherwise be very apt to do from constantly balancing his leg on the toe. After three or four days the hot fomentations will have done what is wanted, and a cold lotion may be applied by means of a loose linen bandage. The best is composed as follows :

Take of Muriate of Ammonia . . . . 2 oz.

Vinegar . . . . : : $1 / 4$ pint.

Methylated Spirit of Wine . . . 3 pint.

Water. . . . ... . . 2 quarts. Mrix. 
With this the bandage should be kopt constantly wet, the application being continued for a fortnight at least, during which time the patient must be kept cool, by lowering his food, and giving him a dose of physic. At the end of three weeks or a month from the accident, the leg must be either blistered or fired, the choice depending upon the extent of injury, and the desire to aroid a blemish if such a feeling exists. The latter is the more efficacious plan, no doubt, but blistering will frequently suffice in mild cases. If, however, the tendons at the end of a month continue greatly enlarged, a cure can hardly bo expected without the use of the "irons."

\section{BBEAKING DOWN.}

"Stonehenge" says :

"Great confusion exists among trainers as to the exact nature of this accident, which is considered by the veterinary surgeon to consist in an actual rupture of the suspensory ligament, either above or below the sesamoid bones, which, in fact, merely separate this apparatus of suspension into two portions, just as the patella intervenes between the rectus femoris and the tibia. Whichever part of the suspensory apparatus is gone (whether the superior or inferior sesamoidal ligament is immaterial), the fetlock and pastern joints lose their whole inelastic support; and the flexor tendons, together with their ligamentous fibres, which they receive from the carpus, giving way, as they must do, to allow of the accident taking place, the toe is turned up, and the fetlock-joint bears upon the ground. This is a complete 'break down;' but there are many cases in which the destruction of the ligamentous fibres is not complete, and the joint, though much lowered, does not actually touch the ground. These are still called breaks down, and must be regarded as such, and as quite distinct from strains of the flexor tendons. The accident generally occurs in a tired horse, when the flezor muscles do not continue to support the ligaments, from which circumstance it so often happens in the last few strides of a race. The symptoms are a partial or entire giving way of the fetlcck-joint downwards, so that the back of it either touches the ground, or nearly so, when the weight is thrown upon it. Usually, however, after the horse is pulled up, he hops on three legs, and refuses altogether to put that which is broken down to the ground. In a very fow minutes the leg "fills" at the seat of the accident, 
and becomes hot and very tender to the touch. There can, therefore, be no doubt as to the nature of the mischief, and the confusion to which allusion has been made is one of rames rather than of facts. Treatment can only be directed to a partial recovery from this accident, for a horse broken down in the sense in which the term is here used can only be used for stud purposes or at slow farm work. A patten shoe should at once be put on after bleeding at the toe to a copious extent, and then fomentations followed by cold lotions should be applied, as directed in the last section. As there must necessarily be a deformity of the leg, there can be no objection on that score to firing, and when the serere inflammation following the accident has subsided, this operation should be thoroughly performed, so as to afford relief not only by the counter-irritation which is set up, and which lasts only for a time, but by the rigid and unyielding case which it leaves behind for a series of years."

THe Hip JonT, or round bone, is liable to be strained by the hindfeet slipping and being stretched apart, or by blows against the side of the stall, when cast, which are not sufficient to dislocate the femur, but strain its ligaments severely. The consequence is an inflammation of the joint, which is evidenced by a dropping of one hip in going, the weight being thrown more upon the sound side than upon the other. This is especially remarkable on first starting, the lameness soon going off in work, but returning at rest. The case is a rare one, but when it does happen, it is very apt to lead to a wasting of the deep muscles of the haunch, which nothing but compulsory work will restore to a healthy condition. The only treatment necessary in the early stage of strain of the hip-joint is rest and cooling diet, etc. ; but, after six weeks or two months, a gradual return to work is indispensable to effect a cure.

STRAINs of THE STIFLE, independently of blows, are rare. The symptoms are a swelling and tenderness of the joint, which can be ascertained by a careful examination; and on trotting the horse, there is manifested a difficulty or stiffness in drawing forward the hindleg under the belly. The ireatment must be by bleeding and physicking in the early stage, together with hot fomentations to the part, continued every hour until the heat subsides. After a few days, if the joint is still painful, a large blister should be applied, or what is still better, a seton should be inserted in the skin adjacent. 
TuE Hock itself is liable to strain, independently of the peculiar accident known as "curb." When it occurs there is some heat of the part, with more or less lameness, and neither spavin, thoroughpin, nor curb to account for them. The injury is seldom severe, and may be relieved by fomentations for a day or two, followed by cold lotions, as presented above, for strain of the back sinews.

The lower part of the posterior surface of the os calcis is firmly united to the cuboid and external metatarsal bone by two strong ligamentous bands, called the calcaneo-cuboid and calcaneo-metatarsal ligaments. The centre of these ligaments is about seven or eight inches below the point of the hock, and when a soft but elastic swelling suddenly makes its appearance there, it may with certainty be asserted that a "curb" has been thrown out. The accident occurs somewhat suddenly; but the swelling and inflammation do not always show themselves until after a night's rest, when the part is generally enlarged, hot, and tender. The precise extent of the strain is of little consequence; for whatever its nature the treatment should be sufficiently active to reduce the ligaments to their healthy condition. Some horses have naturally the head of the exiernal small metatarsal bone unusually large, and the hock so formed that there is an angle between the large metatarsal bone and the tarsus, leaving a prominence, which, however, is harl and bony, and not soft and elastic, as is the case with curb. Such hocks are generally inclined to throw out curbs; but there are many exceptions, and some of the most suspicious looking joints have been known to stand sound for years. Curbs are seldom thrown out by very old horses, and usually occur between the commencemence of breaking-in, and the seventh or eighth year, though they are not unfrequently met with in the younger colt, being occasioned by his gambols over hilly ground. The treatment should at first be studiously confined to a reduction of the inflammation; any attempt to procure absorption before this is effected being injurious in the extreme. If there is much heat in the part, blood may be taken from the thigh vein, the corn should be remored, and a close of physic given as soon as practicable. The curb should then be kept wet (by means of a bandage lightly applied) with the lution recommended for capped hocks, and this should bo continued until the inflanmation is entirely gone. During this treaiment, in bad cases, a patten shoe should be kept on, so as to keep the hock as 
straight as possible, and thas take the strain off the ligaments which are affected. After the part has become cool, it may be reduced in size, by causing absorption to be set up; which is best effected by the application of mercury and iodine (both of which possess that power), in such a shape as to cause a blister of the skin. The biniodide of mercury has this double advantage, and there is no application known to surgery which will act equally well in effecting the absorption of a curb. It should be applied in the mode recommended at page 109, and again rubbed on at an interval of about a week, for three or four times in succession, when it will generally be found that the absorption of the unnatural swelling is effected; but the ligaments remain as weak as before, and nothing but exercise (not too severe, or it will inflame them again) will strengthen them sufficiently to prevent a return. Friction with the hand, aided by a slightly stimulating oil (such as neat's-foot and turpentine wixed, or neat's-foot and oil of origanum, or, in fact, any stimulating essential oil), will tend to strengihen the ligaments, by exciting their vessels to throw out additional fibres; and in the course of time a curb may be considered to be sufficiently restored to render it tolerably safe to use the borse again in the same way which originally produced it.

By Dislocation is meant the forcible removal of the end of a bone from the articulating surface which it naturally occupies. In the horse, from the strength of his ligaments, the accident is not common; those that do occur being chiefly in the hip-joint, and in that between the patella and the end of the femur.

DisLocation of THE HIP-JOINT is known by the rigidity of the hindleg, which cannot be moved in any direction, and is carried by the horse when he is compelled to attempt to alter his position. There is a flatness of the haunch below the hip, but the crest of the ilium is still there, and by this the accident may be diagnosed from fracture of that part. No treatment is of the slightest avail, as the part cannot be reduced, and the horse is useless except for stud purposes. The accident is not very common.

Dislocation of THE PATELLA sometimes becomes habitual, occurring repeatedly in the same horse, apparently from a spasmodic contraction of the external vastus muscle, which draws the patella outwards, and out of the trochlea formed for it in the lower head of the fomur. When the cramp goes off, the patella drops into its 
place again as soon the horse moves, and no treatment is required. Occasionally, however, the dislocation is more complete, and nothing but manual dexterity will replace the bone in its proper situation. Great pain and uneasiness are expressed, and the operator must encircle the haunch with his arms, and lay hold of the patella with both hands, while an assistant drags forward the toe, and thus relaxes the muscles which are inserted in it. By forcibly driving the patella into its place, it may be lifted over the ridge which it has passed, and a snap announces the reduction.

THE KKEE is the joint most frequently suffering from wound, being liable to be cut by a fall upon it, if the ground is rough; and if the accident takes place when the horse is going at a rapid pace, the skin, ligaments and tendons may be worn through by friction against the plain surface of a smooth turnpike road. Whether the joint itself is injured, or only the skin, the accident is called a "broken knee," and for convenience sake, it will be well to consider both under the present head.

When a broken knee consists merely in an abrasion of the skin, the attention of the groom is solely directed to the restoration of the hair, which will grow again as well as ever, if the bulbs or roots are not injured. These are situated in tho internal layer of the true skin, and, therefore, whenever there is a smooth red surfaco displayed, without any difference in the texture of its parts, a confident hope may be expressed that there will be no blemish. If the skin is penetrated, either the glistening surface of the tendons or ligaments is apparent, or there is a soft layer of cellular membrane, generally containing a fatty cell or two in the middle of the wound of the skin. Even here, by proper treatment, the injury may be repaired so fully, that the space uncovered by hair cannot be recognized by the ordinary observer, and not by any one without bending the knee and looking very carefully at it. The best tratment is to foment the knee well with water, so as to removo every particlo of grit or dirt; go on with this every hour during the first day, and at night apply a bran poultice to the knee, which should be left on till the next morning. Then cleanse the wound, and apply a little spermacetti ointment, or lard without salt, and with this keep the wound pliant until it heals, which if slight it will in a few days. If the skin is pierced there will generally be a growth above it of red flabby granulations, which should be care- 
fully kept down to its own level (not beneath it), by the daily use of blue stone, or, if necessary, of nitrate of silver. As soon as the wound is perfectly healed, if the horse can be spared, the whole front of the knee and skin should be dressed with a mild blister, which will bring off the hair of the adjacent parts, and also encourage the growth of that injured by the fall. In about three weeks or a month from its application, the leg will pass muster, for there will be no difference in the color of the old and new hair as there would have been without the blister, and the new will also have come on more quickly and perfectly than it otherwise would.

When the joint itself is opened the case is more serious, and there is a risk not only of a serious blemish, which can seldom be avoided, but of a permanent stiffness of the leg, the mischief sometimes being sufficient to lead to constitutional fever, and the local inflammation going on to the destruction of the joint by anchylosis. The tratinent should be directed to cleanse and then close the joint, the former object being carried out by a careful ablution with warm water, continued until there is no doubt of all the dirt and grit having been removed. Then, if there is only a very small opening in the capsular ligament, it may be closed by a careful and light touch of a pointed iron heated to a red heat. Generally, however, it is better to apply some dry carded cotton to the wound, and a bandage over this, leaving all on for four or five days, when it may be remored and reapplied. The horse should be bled largely and physicked, taking care to prevent all chance of his lying down by racking him up. He will seldom attempt to do this, on account of the pain occasioned in bending the knee, but some animals will disregard this when tired, and will go down somehow. When the cotton is reapplied, if there are granulations above the level of the skin, they must be kept down as recommended in the last paragraph, and the subsequent treatment by blister may be exactly the same. By these means a very extensive wound of the knee may be often speedily cured, and the blemish will be comparatively trifling.

The knee is sometimes punctured by a thorn, causing great pain and lameness. If it can be felt externally, it is well to cut down upon it and remove it; but groping in the dark with the knife among important tendons in front of the knee should not be attempted. The knee should be well fomented, fivo or six 
times a day, until •the swelling, if there is any, subsides, and, in process of time, the thorn will either show its base, or it will grad. ually free itself from all its attachments, and lie beneath the skin, from which position it may be safely extracted with the knife. 


\section{CHAPTER SEVENTEENTH.}

\section{DISEASES OF THE HORSE.}

Internal diseases-Catarrh-Distemper-Bronchitis-Chronic cough-Roaring and whistling-Pneumonia-Congestion-Pleurisy-Broken windPhthisis-Bleeding at the nose.

WE have hitherto been dealing with diseases and difficulties whose presence is indicated by some external sign, visible to the eye, or to be detected by feeling. We now come to a class of not less important erils, which are strictly internal, and although their effects may be visible in emaciation, or other indications of bad condition, their nature, locality and extent can only be judged of by actual trial and careful observation, and this will be necessary to determine their treatment even after their character has been sufficiently announced.

There is nothing more important than that a horse's wind should be sound. No matter how perfect may be his other machinery, - if his respiratory organs are out of order, his elegant shape and serviceable limbs become of little account if he has "bellows to mend." The inexperienced observer will here meet with special difficulties, and will do well to pay careful heed to such hints as we are about to give him.

Diseases of the chest are of a most deceptive and treacherous nature, and may gain very dangerous headway before they give any external signs that would be detected except by a practised horseman, but in most of them the first symptoms are a disturbance or difficulty in breathing. These may be manifest even when the horse is quiet, but in some forms are only developed by action. During or immediately after a sharp trot or gallop the breathing will be very apt to "speak for itself."

Dr. Walsch says :

"CATARRI may be considered under two points of view; either as an inflammation of the mucous membrane of the nasal cavities, accompanied by slight general fever; or as an ephemeral fever of 
three or four days' duration, complicated with this condition of the nose. The latter is, perhaps, the more scientitic definition, but for common purposes it is more convenient to consider it as mainly consisting in the most prominent symptom. There is invariably some degree.of feverishness, sometimes very considerable, at others so slight as to be easily passed over. Usually the pulse is accelerated to about forty or fifty, the appetite is impaired, and there is often sore throat, with more or less cough. On examining the interior of the nostrils, they are more red than natural, at first dry and swollen, then bedewed with-a watery discharge which soon becomes yellow, thick, and, in bad cases, purulent. The eyes aro generally involved, their conjunctival coat being injected with blood, and often some slight weeping takes place, but there is always an expression of sleepiness or dulness, partly owing to the local condition of the organ, and partly to the general impairment of the health. The disease is caused, in most instances by a chill, cither in the stable or out, but sometimes, even in the mildest form, it appears to be epidemic. The treatment will greatly depend upon the severity of the seizure; usually, a bran-mash containing from six drachms to one ounce of powdered nitre in it, at night, for two or three consecutive periods, will suffice, together with the abstraction of corn, and, if the bowels are confined, a mild dose of physic should be given. In more severe cases, when there is cough and considerable feverishness, a ball composed of the following ingredients may be given every night:-

Take of Nitrate of Potass . . . . 2 drachms.

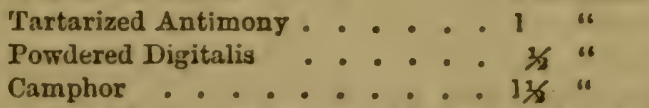

Linseed meal and boiling water enough to make into a ball.

"If the throat is sore, an embrocation of equal parts of oil, turpentine, tincture of cantharides, and hartshorn, may be rubbed in night and morning.

"Should the disease extend to the bronchial tubes, or substance of the lungs, the treatment for bronchitis or pneumonia must be adopted.

"The stable should be kept cool, taking care to make up for the difference in temperature by putting on an extra rug; water should be allowerl ridl libitum, and no corn should be given. 
"Somenmes the discharge becomes chronic. and it is then known by the name ozena.

"INFLUENZA, or distemper, may be considered to be an epidemic catarrh, but the symptoms are generally more severe, and leavo greater prostration of strength behind them. They also require more careful treatment, which must be specially adapted to the attack, for remedies which will arrest the disease in one year will totally fail the next time that the epidemic prevails. The fever. of late years has had a tendency to put on the typhoid type, and bleeding, which formerly was often beneficiai, is now completely forbidden. The symptoms are at first similar to those already described as pertaining to common catarrh, but after a few days the accompanying ferer is more severe than usual, and does not abate at the customary period. The appetite is altogether lost, and the appearance of the patient is characteristic of severe disease rather than of a trifling cold. It is, howerer, chiefly from the fact that a number of horses are seized with similar symptoms, either at the same time or rapidly following one another, that the disease is recognized. 'It usually prevails in the spring of the year, or in a wet and unhealthy autumn. Sometimes almost every case runs on to pneumonia, at others the bronchial mucous membrane alone is attacked; but in all there is extreme debility in proportion to the apparent nature of the disease. The ordinary appearances exhibited in recent epidemics have been as follows:-The first thing observed is a general slight shivering, accompanied by a staring coat. The pulse is weak and slightly accelerated, but not to any great extent; . the mouth feels hot; the eyes and the nostrils are red; the belly is tucked up; there is no appetite; cough, to a varying extent, begins to show itself; and there is generally a heaving of the flanks. The legs and feet are not cold as in pnoumonia, but beyond this they afford no positive signs. The cellular membrane around the eyes and of the legs, generally swells about the second day, and often the head and limbs become quito shapeless from this cause. In the early stage the bowels are often relaxed, but afterwards they are as frequently confined. Scre throat is a very common complication, but it is not by any means an invariable attendant on influenza. It is, however, somewhat difficult to ascertain its existence, as in any case there is no appetite for food. The trentment should be conducted on the principle of 
husbanding the strength, and, unless urgent symptoms of inflammation show themselves, the less that is done the better. If the trachea or larynx is involved only slightly, counter-irritation, by means of a liquid blister, must be tried, without resorting to strong internal medicines; but if serious mischief ensues, the case must, to a certain extent, be treated as it would be when coming on without the complication of influenza, always taking care to avoid bleeding, and merely acting on the howels by gentle aperients, and on the skin and kidneys by the mildest diaphoretic and diuretic. Tho following is the ordinary plan of treatment adopted :

Take of Spirit of Nitric Ether ..... . $1 \mathrm{oz}$

Laudanum ....... 4 drachms.

Nitrate of Potass . . . . . . 3 drachms.

Water . . . . . . . . . l pint.

Mrix, and give as a drench, night and morning.

"By constantly offering to the horse thin gruel (taking care that it does not become sour), and no plain water, sufficient nourishment may be given, as his thirst will induce him to drink.

"During the stage of convalescence the greatest care must be taken. At first, as soon as the cough has somewhat subsided, a mild stomachic ball will be desirable, such as

Take of Extract of Gentian . . . . 6 drachms.

Powdered Ginger ...... 2 drachms. Mrix.

Afterwards, if the case goes on favorably, and the appetite returns, the restoration may be left to nature, giving the horse by degrees his ustal allowance of corn, and adding to his morning and evening feed one drachm of sulphate of iron in fine powder. It must not be attempled to give this until the appetite is pretty keen. or tho horse will be disgusted, and will probably refuse his corn altogether. .

"Should typhoid symptoms be clearly established, the case must be treated according to the directions hereafter laid down for typhus ferer.

"Broxchits is an inflammation of the mucous membrane lining the bronchi, and almost invariably extending to these parts through the trachea, from the larynx and nasal passages, which are primarily affected as in ordinary cold. The membrane in the early stage becomes filled with blood, and as a consequence the diameter of the tubes is diminished, attended by some difficulty, and in- 
creased rapidity of breathing. After a time a frothy mucous is poured out from it, and this still further interferes with respiration, and necessitates a constant cough to get rid of it. These symptoms are always present, but they will vary greatly in intensity, and in the rapidity with which they progress, from which circumstances bronchitis is said to be acute or clironic, as the case may be. In the acute form there are also several variations, and reterinary writers are in the habit of again subdividing it into acute and sub-acute, but the two leading divisions are sufficient for all practical purposes. It begins with the usual premonitory appearances of a severe cold, accompanied by a staring coat, and entire loss of appetite. The breathing is somewhat quicker than natural, and the pulse is raised to sixty or seventy. The legs remain of the usual temperature, and there is a hard dry cough, the lining membrane of the nostrils being intensely red, and in severe cases dry and swollen. On auscultation there is a dry rattling sound, very different from the crepitation of pneumonia, and as soon as mucous is secreted, succeeded by gurgling, and, soap-bubble sounds, easily distinguished when once heard. If the attack goes on farorably, the cough becomes loose, and there is a free discharge of mucous, both from the lungs, as evidenced by the nature of the cough, and from the nostrils as shown by the running from them. On the other hand, the promise is unfavorable when the breathing is very laborious, with the legs extended, and the cough constant and ineffectual in affording relief. Should no relief be afforded, death takes place a a week or ten days after the onset of the disease, from suffocation. The treatment should depend greatly upon the urgency of the inflammation, which only an experienced eye can judge of. If slight, nitre and tartar emetic internally, and a blister (to one or both sides, according to the extent of bronchi involved), will suffice, but in very severe cases blood must be taken at the onset, or it will be impossible to control the inflammation. Bleeding should be avoided if it is judged prudent to do so, for of late years the type of diseases has changed so much in the horse, that he is found to bear loss of blood badly. Nevertheless, it is not wise to lay down the rule that it is never desirable. The bowels must be acted on by the ordinary physic ball, resorting to raking and clysters, if the time cannot be afforded for the usual laxative preparation. For 
the special control of the morbid state of the membrane the following ball will be found advantageous:

$$
\begin{aligned}
& \text { Take of Digitalis } \ldots \ldots \ldots \text {. . . . drachm } \\
& \text { Calomel ........ 1/ drachm. } \\
& \text { Tartar Emetic . . . . . . } 60 \text { to } 80 \text { grains }
\end{aligned}
$$

Mrix with treacle, and give twice a day.

Should the disease continue after the blister is healed, a large seton may be put in one or both sides with advantage.

"Chronic BRoNCHITIS seldom exists except as a sequel to tho ncute form, and after adopting the balls recommended for that state, it may be treated by attention to the general health, a seton in the side, and the exhibition of an expectorant ball twice a day, composed of the following materials:

Take of Gum Ammoniacum . . . . . $3 / 2 \mathrm{oz}$

Powdered Squill ...... 1 drachm.

Castile Soap . . . . . . 2 drachms.

Mix and make into a ball.

BY curonic covar is understood a cough that comes on without any fever or evidences of the horse having taken cold. It differs in this respect from chronic bronchitis, which generally supervenes upon the acute form, and is always attended in the early stage by feverishness. It appears probable that chronic cough is dependent upon an unnatural stimulus to the mucous membrane, for it almost always malies its appearance when much corn is given without due preparation, and ceases on a return to green food. It is, therefore, very commonly termed a stomach cough. The symptoms are all summed up in the presence of a dry cough, which is seldom manifested while in the stable, but comes on whenever the breathing is hastened by any pace beyond a walk. Two or three coughs are then given, and the horse perhaps is able to go on with his work, but after resting for a few minutes, and again starting, it comes on again, and annoys the rider or driver by its tantalizing promise of disappearance followed by disappointment. Very often this kind of cough is caused by the irritation of worms, but any kind of disorder of the digestive organs appears to have the power of producing it. The usual treatment for chronic bronchitis seems here to be quite powerless, and the only plan of proceeding likely to be attended with success, is to look for the cause of the irritation, and remove it. Sometimes this will be found in a hot stable, the horrse 
having previously been accustomed to a cool one. Here the alteration of the temperature by ten or fifteen degrees will in a few days effect a cure, and nothing else is required. Again, it may be that the corn has been overdone, in which case a gentle dose of physic, followed by a diminished allowance of corn, and a bran-mash twice a week, will be successful. If the stomach is much disordered, green food will be the best stimulus to a healthy condition, or in its absence a few warm cordial balls may be tried. The existence of worms should be ascertained in doubtful cases, and if they are present, the proper remedies must be given for their removal. Linseed oil and spirit of turpentine, which are both excellent worm remedies, are highly recommended in chronic cough, and whether or not their good effect is due to their antagonism to worms, they may be regarded as specialiy useful.

"A very successful combination is the following mixture:

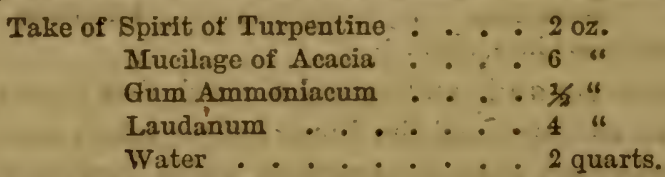

Mix, and gire half a pint, as a drench, every night; the bottle must bo well shaken before pouring out the dose.

LARTNGITIS, ROARING, WHISTLING, ETC.

"One of the most common diseases among horses, is the existence of some mechanical impediment to the passage of the air into the lungs, causing the animal to "make a noise." The exact nature of the sound has little practical bearing on the cause that produces it; that is to say, it cannot be predicated that roaring is produced by laryngitis; nor that whistling is the result of a palsy of some particular muscle, but undoubtly it may safely be asserted that all lesions of the larynix, by which the shape and area of its opening are altered and diminished, are sure to have a prejudicial effect upon the wind, and either to produce roaring, whistling, wheezing, or trumpeting, but which would result it might be difficult to say, although the precise condition of the larynx were known, which it cannot be during life. Until recently veterinary surgeons were puzzled by often finding on examination of a roarer's larynx after death no visible organic change in the opening, and many were led to imagine that this part could not be the seat of the disease. On a careful dissection, however, it is found that a muscle or muscles 
whose office it is to dilate the larynx is wasted and flabby. The other muscles are perhaps equally atrophied, but as their office is to close the opening, their defects are not equally injurious, and at all erents are not shown by producing an uunatural noise.

"BY ACUTE LARY:itis is meant a more than ordinary inflammation of the larynx, and not that slightly morbid condition in which the mucous meinbrane of that organ is always involved in " the passage of a cold into the chest." In the latter state the ear detects no unusual sound, and indeed there is plenty of room for the air to pass. But in true laryngitis, on placing the ear near the throat, a harsh rasping sound is heard, which is sufficient at onco to show the nature and urgency of the symptoms. The mucous membrane is swollen, and tinged with blood; the rima glottidis is almost closed, and the air in passing through it produces the sound above described, which, however, is sometimes replaced by a hissing one. In conjunction with these well marked symptoms there is always a hoarse cough of a peculiar character, and some considerable fever, with frequent respiration, and a hard, wiry pulse of seventy to eighty. The treatment must be of the most active kind, for not only is life threatened, but even if a fatal result does not take place, there is great danger of permanent organic mischief to the delicate apparatus of the larynx generally from tho effusion of lymph into the submucous cellular membrane. A full bleeding should at once be practised, and repeated at the end of twelvo hours if there is no relief afforded and the pulse still continues hard. The hair should be cut off the throat, and the tincture of cantharides brushed on in a pure state until a blister arises, when the part may be constantly well fomented, to encourage the discharge. Large doses of tartar emetic, calomel, and digitalis, must also be given, but their amount and frequency should be left to an experionced vetcrinarian, the preliminary bleeding and blistering being done in his absence to sare time. It is a case in which medicine must be pushed as far as can be done with safety, and this cannot well be left to any one who is not well acquainted with its effects, and with the powers of the animal economy. Gruel is the only food allowed during the acute stage, and there is seldom time to have recourse to aperient physic until the urgent symptoms are abated, when an ordinary dose may be given. During convalescence the greatest care must be taken to prevent a relapse, 
by avoiding all excitement either by stmulating food or fast ex ercise.

"CHRoNIC LARYNGITIS may occur as the result of the acute form above described, or it may come on gradually, without any violent inflammation preceding it. In either case the symptoms are similar in their nature to those met in the acute form, but less in degree. The noise made is not nearly so harsh, and can often hardly be heard on the most careful examination. The peculiar harsh, grating cougb is, hotrever, always present, and by it the nature of the case may generally be easily made out. The disease often accompanies strangles, although in nine cases out of ten it is overlooked. Very commonly, however, it makes its ravages in so insidious a manner that no suspicion is felt of its presence, until the horse begins to make a noise, though he must in all probability have shown by the cough peculiar to the complaint, that it has been working its way for some weeks at least."

Whatever may be the cause there can be no doubt that the trcatment is most troublesome, and often baffles the skill of the most accomplished veterinarian. Blistering is not so useful as counter-irritation by a seton, which must be inserted in the lonse skin beneath the jaw, as close as possible to the larynx. This alone will do much towards the cure, but no pains must be spared to assist its action by a cooling regimen, consisting of bran-mashes, and if in the spring or summer, green food, or in the winter, carrots. Corn must be entirely forbidden, and the kidneys should be encouraged to act freely by two or three drachms of nitre given in the mash twice a day. When the case is very intractable, the nitrate of silver may be applied to the part itself by means of a sponge fastened to a piece of flexible cane or whalebone. The mouth should then be kept open with the ordinary balling iron, and the sponge rapidly passed to the situation of the top of the larynx, and held there for a second, and then withdrawn.

Dr. Walsch says :

"ROARING is the bugbear of the purchaser at the hammer, and not without good reason. The most experienced veterinarian, or dealer, will often fail to ascertain its existence, in spite of all the artifices he may call into play. Not the slightest sound is heard during a state of quiescence, or even when the horse is trotted or galloped for the short distance which "the ride " will afford. The 
blow on the side given with due artistic effect elicits no grunt, and yet the animal is a contirmed roarer, and not worth a shilling perhaps for the purpose to which he is intended to be devoted. On the other hand, many a sound horse is condenned as a roarer for giving out the obnoxious grunt; and though there is no doubt that this sign may be relied on in a great many cases, yet it cannot be accepted as either negatively or positively a certain proof. T'he only real trial is the noiseless gallop on turf or plough, when the ear can detect the slightest sound, and can distinguish its exact nature, and the precise spot from which it proceeds. Many a horse will, when he is excited, make a harsh noise in his breathing, accompanied by a kind of "gluck," proceeding from a spasmodic flapping of the velum palati ; but on galloping him all this goes off, and he may probably exhibit excellent wind. Such cases I have many times known, and they would be condemned as unsound by those who have had little experience, or are content with a careless and inefficient trial. Stallions are particularly prone to make this kind of noise, and it is extremely difficult to ascertain their soundness in this respect by any means which can be safely resorted to. The causes of roaring are of three kinds: 1st, inflammation, which has left a thickening or ulceration of the mucous membrane, or a fungous growth from it; $2 d$, paralysis of the muscles; and $3 \mathrm{~d}$, an alteration of the shape of the cartilages of the larynx, produced by tight reining.

"In roaring produced by an ulcerated or thickened condition of the mucous membrane, or by a fungous growth, the sound elicited is always the same in proportion to the rapidity of respiration. None of the ordinary expedients by which the breath is introduced in a modified stream (such as a full meal, or pressure on the nostrils or windpipe), will be of much-avail, and the horse roars sturdıly whenever his pace is sufficiently accelerated. If a horse so affected can be made to grunt by the blow on the side, the sound will alwars indicate the disease, for it will be harsh and rough, and not the natural grunt of the animal. It is usually supposed that no treatment can be of the slightest avail here.

"Setons, blisters, and embrocations are all useless, as has been proved in numberless cases; and beyond the palliation which can be afforded by employing the horse only at such a pace as his state will allow, nothing else can be suggested.; 
"Where paralysis of the muscles that open the rima glottidis is the seat of the roaring, no plan has yet been suggested which is of the slightest avail.

"An alteration in the shape of the cartilages, so as to permanently c!n? of roa ing. Pressure for a very long time will be required to eficici his, and far more than suffices to paralyze the nerve. Cases, however, are recorded, and the parts have been preserved, so that there can be no doubt of their occasional occurrence. No treatment can be of the slightest service.

"Although roaring, in all its varieties, may be said to be generally incurable, yet it may be greatly palliated by general attention to the state of the lungs and stomach, by proper food."

"HignbLowixg is a perfectly healthy and natural habit, and cannot be confounded with roaring by any experienced horseman. It is solely confined to the nostrils ; and the noise is not produced in the slightest degree during inspiration, but solely during the expulsion of the air, which is more forcible and rapid than usual, and accompanied by'a vibratory movement of the nostrils, which is the seat of the noise. Roaring, on the contrary, continues during inspiration, as well as expiration; and by this simple test the two may readily be distinguished. Most highblowers have particularly good wind, of which the celebrated Eclipse is an example, for there is no doubt that he was addicted to the habit.

Whisturng (and piping, which is very similar to it), are produced by the same causes as roaring, in an exaggerated condition. Thus, a roarer often becomes a whistler as the rima glottidis is more and more closed by disease; on the other hand, the whistler is never converted into a roarer. The noise made is seldom a decidedly shrill whistle, but it has more resemblance to that sound than to roaring, and the name may well be retained, as descriptive of it. Whistlers are always in such a state of confirmed disease, that treatment is out of the question-indeed, they can only be put to the very slowest kind of work.

"WIEEZING is indicative of a contracted condition of the bron chial tubes, which is sometimes of a spasmodic nature, and at others is only brought on during occasional attacks after exposure to cold. The treatment should be that recommended for chronic 
bronchitis, which is the nature of the disease producing theso symptoms.

Pxedroxis, or peripneumonia, must be examined, with a view, first, to its inteusity, whether acute or sub-acule; ard secondly, as to its effects, which may be of little consequence, or they may bo so serious as to completely destroy the subsequent usefulness of the patient. It is not, therefore, alone necessary to provide against death by the treatment adopted, but due care must also be taken that the tissue of the lungs is not disorganized by a deposition of Lymph, or of matter, so as to lead in the one case, to a consolidation of their air-cells, and in the other, to the formation of a large abscess, and consequent destruction of substance. The former is a very cominon sequel of pneumonia. In very severe cases, gangrene of the lungs is induced : but as death almost always speedily follows this condition, it is not necessary to consider it, excepting as bearing upon the fatal result.

The cause of pneumonia may be over-exertion, or it may come on as a primary disease after exposure to cold; or it may follow upon bronchitis when neglected and allowed to run on without check. For these reasons when the lungs are evidently congested, no pains should $b$ s spared to reliere them by causing the skin to act, beforo the aid of nature is invoked, since it can nerer be certain that sho will stop short at the proper point.

CoxGEstiox of THE LUNGS is too often neglected and allowed to go on to inflammation. Veterinary surgeons, indeed, are seldom called in before this stage has run its course and inflarmation is established. The great mass of horse-masters are wholly ignorant of its action, and we shall therefore endeavor to lay down instructions which may bo beneficial to those who are so unlucky as to have a horse with congesterl lungs, either caused by over-exertion, or by a chill, or by a combination of the two, as most frequently happens.

When a horse is put to too severe and rapid, especially too sudden and heating labor, when he is too high in flesh, or when he is but just up from pasture, and has had no opportunity of accustoming himself to the changed order of things, the blood is apt to collect and stagnate in his lungs, from a defect in the circulating apparatus, and he becomes absolutely choked from a want of that decarbonization which is necessary to his existence. He respires 
freely, but circulation in his lungs almost ceases, and in spite of his hurried panting he is almost as completely suffocated as if a cord was tied around his neck. His eyes and nostrils become bloodshot and purple, the vessels being filled with carbonized blood, his heart beats feebly, and his every motion and the expression of his face indicates his distress. Many books on horsemanship recommend copious bleeding, and in slight cases it may do very little harm. Even in them it will do no good, and in severer cases it will destroy the only chance remaining. What the horse wants is not so much depletion as stimulation. Turn his head to the wind; bathe his head and chest in cold water; give him some mild whiskey and water, a quart of that or of ale, and let him stand still awhile. Then lead him to the nearest good shelter, and leave him there for a good rest. This is the best way of treating this description of congestion.

Dr. Walsch prescribes as follows:

"When congestion shows itself as the result of a chill, the following symptoms are displayed :-First and foremost there is rapid and laborious breathing, the horse standing with his legs wide apart, his head thrust straight forward, and his flanks heaving. The skin is generally dry, but if there is any sweat it is a cold one. The legs are icy cold, and also the ears. The whites of the eyes and lining of the nostrils are of a purplish hue, but not very deep in color. The pulse is slightly accelerated (from forty to fifty), but not hard and incomprehensible; and lastly, the attack is of recent duration. These signs, however, are not to be fully relied on as marking congestion rather than inflammation, without having recourse to an examination of the lungs by means of the ear. Placing it against the side of the chest, in inflammation there would be certain marked sounds, presently to be described, whilst in the state we are now considering they are wholly absent, and all that is heard is the usual respiratory murmur slightly increased in intensity. It is of the utmost importance to make out exactly the nature of the case, for the treatment should be very different in congestion and inflammation. If in the former condition the blood can only be drawn into the skin, relief is at once afforded, and all danger is at an end; but in the latter, though some slight advantage would be gained, the progress of the disease would not be materially checked. To produce this determination of blood to the 
Bkin rithout loss of time, is sometimes very difficult ; but by the application of hot water and blankets it may generally be accomplished. Two men, supplied with a tub of very hot water and plenty of clothing, should be rapid in their morements, and proceed as follows :-Have an assistant ready to strip the patient when ordered, then, dipping a blanket in the water, it is taken out and partially wrung, leaving as much water in its meshes as it can hold without dripping; as soon as it is cool enough for the human hand to bear its pressure, it should be gently but quickly laid upon the horso's back, and the rug, which has just come off, while still warm, placed over it, with two or three more over all, the number depending upon the temperature of the air. Another smaller rugr may in the same way be wetted, and applied to the neck, covering it with two or three hoods, but taking care to avoid pressure upon the windpipe. The legs also should be wrapped in flannel bandages made as hot as possible before the fire, but dry. In the course of half an hour, if the skin of the parts uncovered does not become warm, and show evidences of sweating coming on, another rug must be dipped in the same way, and substituted quickly for the first. Usually, however, the desired effect is produced within twenty minutes, and then great care and some little tact are required to manage the operation. If the sweating is allowed to go on beyond a certain point, exhaustion is produced, attended by almost as much danger as inflammation; while on the other hand, in attempting to moderate the action of the skin, risk is incurred of a chill, and thus upsetting all the benefit which might otherwise have been derived. But by throwing open the doors to the external air, which may freely be admitted as soon as the skin acts, and by reducing the number of additional rugs, the amount of sweat given off may be kept within dus bounds, and in the course of two or three hours the previously wetted rug or"blanket may be removed and a dry, warm one substituted for it, but the assistants must be quick and handy in effecting the change. Many a case of inflammation of the lungs, kidneys, or bowels might be stopped at once by the adoption of this plan; but the misfortune is, that it requires all the skill and tact of the veterinary surgeon, first of all to understand the case, and afterwards to manage its treatment.

"TIE SYMPTOMS OF ACUTE PNEUMONIA are a quick and distressed respiration, averaging about sixty inspirations in the minute. 
Pulse quick (from seventy to eighty-five); hard, often small, but always compressible. Nostrils distended, and the lining membrane red (except in the last stage when suffocation is imminent). Cough short, and evidently giving pain, which occasions it to be checked as much as possible. Legs and ears generally cold, often icy. Feet wide apart; evidently with an instinctive desire to dilate the chest as much as possible. On putting the ear to the chest, if the attack is very recent, there will be merely a greatly increased respiratory murmur; but when fully developed there may be heard a crepitant rattling, which is compared to the crackling of a dried bladder; but I confess that I could never make out the similarity between the two sounds. In the later stages this is succeeded by an absence of all sound, owing to the consolidation of the lungs, or by mucous rattles depending upon the secretion of mucous. On tapping the exterior of the chest with the ends of the fingers (percussion), the sound given out is dull in proportion to the extent of mischief, the effect of pneumonia being to convert the spongy texture of the lungs into a solid substance like liver. The treatment will greatly depend upon the stage of the disease, the age and constitution of the horse, and the nature of the prevailing epidemic, if there is one. In modern days bleeding is rery badiy borne, either by man or horse, nevertheless few cases of genuine pneumonia will be saved without it. Sufficient blood must be taken to make a decided impression on the circulation, without which the inflammation will not be mastered. The "quantity necessary for this cannot be fixed, because the effect will vary so materially, that the abstraction of three or four quarts of blood in one case will do more than double or treble that quanity in another. A large orifice must be made in the vein, and it must not be closed until the lining membrane of the nose or the white of the eye is seen to have become considerably paler. It may possibly even then be necessary to repeat the operation six hours afterwards, or next day, according to the symptoms. The rule should be followed of taking enough, but not a drop too much, for blood removed from the circulation takes a long time to replace. With regard to medicine, tartar emetic is the only drug which seems to have much influence over pneumonia, and it must be given every six hours in drachm doses, with from a half drachm to a drachm of powdered digitalis, or white hellebore, to keep down the pulse, and two or three drachins 
of nitre, to increase the action of th kidneys. Dnless the bowels are confined no aperient should be given, and if necessary only the mildest dose should be used. The diet should consist of bran mashes, gruel, and a little hay, or green food, if the season of the vear allows. A cool airy stable, and warm clothing are indispensable in this disease. When the first violence of the attack has subsided, a large blister on the side of the chest will afford great relief, and when it ceases to act if the disease is not entirely cured, a second may be put on the other side.

"SUB-ACUTE PXEUMoria differs in no respect from the acuto form, excepting in degree, and the symptoms and treatment will vary only in proportion."

PLeErisy is characterized by a very peculiar respiration, the expirations boing much longer than the inspirations, owing to the pain which is given by the action of the muscles necessary for the latter, while the former, if the chest is allowed quietly to fall, is almost painless. Nevertheless, the breathing is quicker on the whole than natural. The pulse is quick, small, and incompressible. Nostrils and eyes of a natural color, and the former are not dilated. The countenance is anxious, and the legs are rather drawn together than extended, as in bronchitis and pneumonia, and they are not colder than usual. There is a short hurried cough, with great restlessness, and the sides are always painful on pressure; but this symptom by itself is not to bo relied on, as it is present in pleurodynia, which will be presently described.

The treatmont should consist of copious bleeding, followed by a mild purgative, and the same ball as recommended for pneumonia, with the addition of half a drachm of calomel. Blisters are not desirable to be applied to the sides of the thorax, as there is so littlo space between the two surfaces of the pleura and the skin that they aro apt to do harm by immediately irritating the former, rather than to act beneficially by counter-irritation of the skin. A large rowel may, however, be placed in the breast with advantage.

Between PLEURODYria and the last there is some similarity in the symptoms; but in their nature, and in the treatment required, they are widely separated. It is therefore necessary that they should not be confounded, for in the one case, blood-letting and other active measures may be unnecessarily adopted, and in the other a fatal result will most probably occur for want of them. 
In pleuritis there is a quick pulse, with general constitutional disturbance, which will serve to distinguish it from pleurodynia, besides which, it is rarely that we meet with the former without some other affection of the lungs co-existing. When, therefore, a horse is evidently suffering from acute pain in the walls of the thorax, unaccompanied by cough hurried breathing, quick pulse or fever, it may safely be gathered that the nature of the attack is a rheumatism of the intercostal muscles (pleurodynia), and not pleurisy. In treating it, bleeding and tartar emetic must be carefully avoided, and hot mustard and vinegar rubbed into the sides will be the most likely renedy to afford relief.

When a horse has long been subject to a chronic cough, and, without losing appetite, wastes away rapidly, it may be assumed that he is a victim to phthisis, and especially if he is narrowchested and has long shown signs of short-wind. On examining the chest by the ear, it will be found to give out sounds of various kinds, depending upon the exact state of the lungs; but in most cases there will be great dulness on percussion, owing to the deposit of tubercles, in which the disease consists. In a confirmed case no treatment will avail, and the poor animal had better be destroyed. When the attack is slight, the progress of the disease may be stayed by, counteracting inflammation in the ordinary way, avoiding loss of blood when possible.

A BROKEN-WINDED horse can be detected at once by any horseman possessed of experience, from the peculiar and forcible double expiration. Inspiration is performed as usual, then comes a rapid but not violent act of expiration, followed by a forcible repetition of the same, in which all the muscles of respiration, auxiliary and ordinary, are called into play. This is of course most marked when the horse has been galloped, but even when he is at rest the double expiration is manifest almost at any ordinary distance from the olserver. The disease almost (if not quite) invariably consists in emphysema, or entrance of the air into unnatural cells, which is retained there, as the urine is in the bladder, from the valvular nature of the openings, and cannot be entirely expelled, nor in the slightest degree, without calling into play al! the muscles of the chest. The presence of unchanged air is a constant source of irritation to the the lungs, and although sufficient may be expired easily enough to carry on their functions while 
the body is at rest, yet instinctively therc is a desire to get rid of the surplus, and hence the two acts of respiration. Immediately after this second act the muscles relax, and the flank falls in, and this it is which catches the eye is so remarkable a manner.

The treatment can only be palliative, as there is no recognized cure for the disease, though M. Hew of Chaumont, has lately published a report of ten cases in which treatment by arsenic, given with green food or straw, and in some cases bleeding, was perfectly successful. The arsenic was given to the extent of fifteen grains daily, and at the end of a fortnight the symptoms of broken wind were completely removed; but it is impossible to say whether the cure was permanent. It is known, however, that one of them relapsed after three months, but speedily yielded to a repetition of the treatment. It may certainly be worth while to try the experiment of the effect of arsenic where a broken-winded horse is valuable in other respects. Broken-winded horses should be carefully dieted and even then confined to slow work. The water should never be given within an hour of going out of the stable, but it is better to leave a constant supply, when too much will never be taken. Carrots are peculiarly suited to this disease, and a diet of ban mixed with carrots, sliced, has sometimes been known to relieve a brokenwinded horse most materially.

THICK WIND is the horseman's term for any defective respiration, unaccompanied by a noise, or by the signs of emphysema just al- luded to. It usually follows pneumonia, but it may arise from chronic bronchitis. No treatment will be of any service except such as will aid the play of the lungs mechanically, by avoiding overloading the stomach.

The horse is very subject to hemorrhage from the nose, coming on during violent exertion. Fat over-fed horses are the most likely to suffer from hemorrhage; but most people are aware of the risk incurred in over-riding or driving them, and for this reason they are not so often subject to this accident (for such it is rather than a disease) as they otherwise would be. It is unnecessary to describe its symptoms, and the only point necessary to inquire into is, whether the lungs or the nasal cavities are the seat of the rupture of the vessel. In the former case the blood comes from both nostrils, and is frothy ; while in the latter it generally proceeds from one only, and is perfectly fluid. The treatment should consist in cooling 
the horse clown by a dose of physic and a somewhat lower diet; but if the bleeding is very persistent, and returns again and again, a saturated solution of alum in water may besyringed up the nostril daily, or if this fails, an infusion of matico may be tried, which is far moro likely to succeed. It is made by pouring half a pint of boiling water on a drachm of matico-leaves, and letting it stand till cool, when it should be strained and is fit for use. 


\section{CHAPTER EIGHTEENTH.}

\section{DISEASES OF THY HORSE.}

The abdomen and its appendages-Sore throat-Strangles-Lampas-Gastritis-Dyspepsia-Bots and their history.

Tue horse, as well as his master, is subject to many painful and dangerous diseases of the abdominal viscera and their appendages. They generally exhibit themselves externally, more or less, by emaciation, and a flabby state of the muscles, accompanied by a "staring" coat different in character and feel to that produced by overwork and poor feeding. They are not considered " unsoundness," and for the most part yield readily to treatment, but the latter should be prompt and wise.

Before dealing with those difficulties which come more manifestly under the proper scope of this chapter, we will say a few words more about the mouth and throat, as being in a manner connected therewith.

Sore throAt is readily detected by swelling or hardness of the parts, with difficulty in swallowing. External sweating should at once be resorted to. The tincture of cantharicies diluted with an equal part of spirit of turpentine, and a little oil, may be rubbed in with a sponge until it produces irritation of the skin, which in a few hours, will be followed by a discharge from the part. 'Six or cight drachms of nitre may be dissolved in the water which the horse drinks. He will not like it, but thirst will force him to tako it. If ho eats with more ease than he drinks, the nitre may bo . given in a bran-mash instead of in the water.

STRANGLES.

Between the third and fifth year of the colt's life he is generally seized with an acute swelling of the soft parts between the branches of the lower jaw, accompanied by more or less sore throat, cough and feverishness. These go on increasing for some days, and then an abscess shows itself, and finally bursts. The salivary glands 


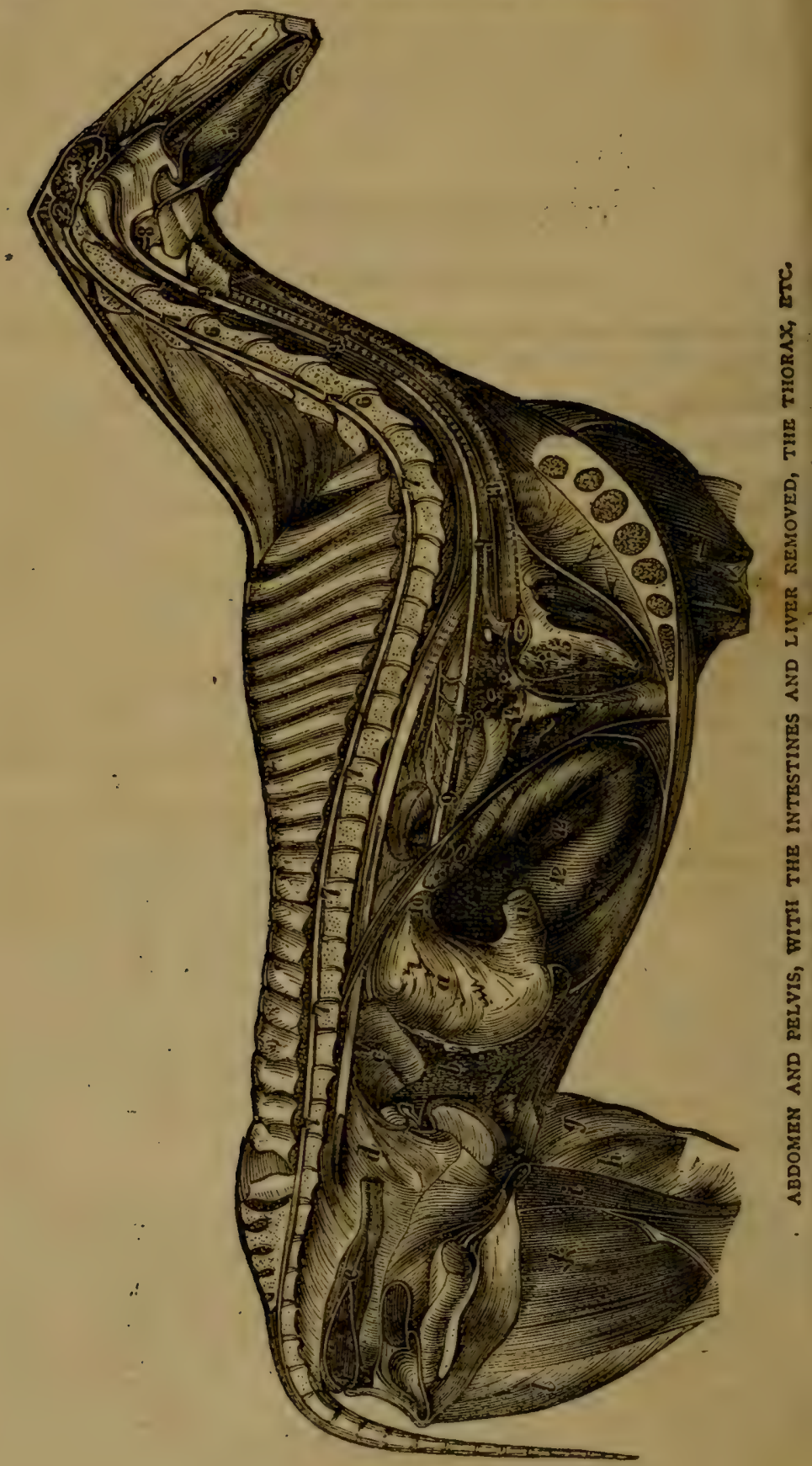


a. The Stomach (ro Cardiac orifice.Is Pylorus.)

\section{Spleen.}

c. Left kidney.

d. Broad ligament of the uterus, with left cornu and ovary displayed.

e. Rectum.

f. Anus.

g. h. i. $j . k$. . Internal muscles of the thigh.

1. Occiput.

2. Cerebellum.

3. Cerebrum.
4. Nasal membrane.

5. Tongue.

6. 6. Cervical vertebra.

7. 7.7. 7. Spinal cord.

8. Pharynx.

9. 9. 9. CEsophagus.

10. Cardiac orifice of the stomach passing through the diaphragm.

38. Pylorus.

12. 12. Posterior surface of the dia. phragm.

83. 25. Trachea.

14. Lungs.

25. Heart. 
are often involved, but the matter forms in the cellular membrane external to them. The treatmont should be addressed to the control of constitutional symptoms by the mildest measures, such as bran-mashes with vitre in them, abstraction of corn, hay tea, etc. At the same time the swelling should be poulticed for one night, or thoroughly fomented two or three times, and then blistered with the tincture of cantharides. As soon as the matter can plainly be feit, it may be let out with a lancet; but it is very doubtful whether it is not the best plan to permit the abscess to break. The bowels should be gently moved, by giving a pint, or somewhat less, according to age, of castor oil ; and afterwards two or three drachms of nitre with half a drachm of tartar emetic may be mixed with the mash twice a day, on which food alone the colt should be fed, in addition to gruel, and a little grass or clover, if these are to be had, or if not, a few steamed carrots. The disease has a tendency to get well naturally, but if it is not kept within moderate bounds it is very apt to lay the foundation of roaring or whistling. Any chronic swelling which is left behind may be remored by rubbing in a weak ointment of biniodide of mercury (one scruple or half drachim to the ounce.)

LAMPAS is an active inflammation of the ridges, or "bars," in the roof of the mouth, generally occurring in the young horse while he is shedding his teeth, or putting up the tushes. Sometimes, however, it comes on, independently of this cause, from over-feeding with corn after a run at grass. The mucous membrane of the roof of the mouth swells so much that it projects below the levelof the nippers, and is so tender that all hard and dry food is refused. The treatment is extremely simple, consisting in the scarification of the part with a sharp knife and lancet, after which the swelling generally subsides, and is gone in a day or two; but should it obstinately continue, as will sometimes happen, a stick of lunar caustic must be gently rubbed over the part every day until a cure is completed. This is far better than the red-hot iron, which was formerly so constantly used. If the lampas is owing to the cutting of a grinder, relief will be afforded by a cross-cut across the protruding gum.

BARBS, PAPS, ETC.

The swelling at the mouth of the ducts may generally be re- 
lieved by a dose of pliysic and green "food,"but should it continūe, a piece of lunar caustic may be held, for a moment, against the opening of the duct every second day, and after two or three ap plications the thickening will, suddenly disappear.

Gastritis (acute inflammation of the stomach) is extremely raro in the horse; but it sometimes occurs from eating regetable poisons as food, or from the wilful introduction of arsenic into this organ, or, lastly, from licking off corrosive external applications, which have been used for mange. The symptoms from poisoning will a good deal depend upon the article which has been taken, but in almost all cases in which regetable poisons have been swallowed, there is a strange sort of drowsiness, so that the horse does not lie down and go to sleep, but props himself against a wall or tree with his head hanging almost to the ground. As the drowsiness increases he often falls down in his attempt to rest himself more completely, and when on the ground his breathing is loud and hard, and his sleep is so unnaturally sound that he can scarcely be roused from it. At length convulsions occur, and death soon takes place. The trcatment, in each case, should be by rousing the horse mechanically, and at the same time giving him six or eight drachmis of aromatic spirit of ammonia, in a pint or two of good ale, with a little ginger in it. This may be repeated every two hours, and the horse should be perpetually walked about until the narcet:c symptoms are completely gone off, when a sound sleep will resture him to his natural state.

Corrosive sublimate is sometimes employed as a wash in mange, or to destroy lice, when it may be licked off. The tratment consists in a similar use of thin starch or gruel; or, if the poison has recently been given wilfully, of large quantities of white of egg.

Every domestic animal suffors in health if he is constantly fed on the sâme articles, and man himself perhaps more than they do. Wo cannot, therefore, wonder that the master is often told that some one or other of his horses is " a little off his feed; " nor should we be surprised that the constant repetition of the panacea for this, "a dose of physic," should at length permanently establish the condition which at first it would always alleviate. It is a source of wonder that the appetite continues so good as it does, in the majority of horses, which are kept in the stable on the same kind of food, always from July to Mas, and often through the other 
months also. The use of lucerne, or clover, in the spring, is supposed to be quite sufficient to restore tone to the stomach, and undoubtedly they are better than no change at all; but at other seasons of the year something may be done towards the prevention of dyspepsia, by varying the quality of the hay, and by the use of a few carrots once or twice a week. In many stables one rick of hay is made to serve the whole, or a great part of the year, which is a very bad plan, as a change in this important article of food is as much required as a change of pasture when the animal is at grass. When attention is paid to this circumstance, the appetite will seldom fail in horses of a good constitution, if they are regularly worked; but without it, resort must occasionally be had to a dose of physic. It is from a neglect of this precaution that so many horses take to eat their litter, in preference to their hay; for if the same animal was placed in a straw-yard, without hay, for a month, and then allowed access to both, there would be little doubt that he would prefer the latter. Some horses are naturally so voracious, that they are always obliged to be supplied with less than they desire, and they seldom suffer from loss of appetite; but delicate feeders require the greatest care in their management. When the stomach suffers in this way, it is always desirable to try what a complete change of food will do before resorting to medicine; and, if it can be obtained, green food of some kind should be chosen, or if not, carrots, or even steamed potatoes. In place of hay, sound wheat or barley straw may be cut into chaff, and mixed with the carrots and corn; and to this a little malt-dust may be added, once or twice a week, so as to alter the flavor. By continually changing the food in this way, the most dyspeptic stomach may often be restored to its proper tone, without doing harm with one hand while the other is doing good, as is too often the case with medicine.

\section{Bots.}

In enumerating the so-called diseases of the horse, it would hardly be fair to other writers to omit so fruitful a subject of useless discussion as the "bots," but after all, what we can say will have its greatest value as a warning, and preventive of aimless and injurious quackery, for the bots, properly considered, do not constitute a "disease." Let us give the subject a common sense and half-way scientific examination. 
What are called "bots" are the larre, or grub, of a species of gadfly which seems to come into being wherever the horse is introduced, if it did not exist there before. This fly is known to science as the astrus equi, and the grubs are provided with a pair of hooks or nippers, by which they adhere to the inner membrane of , the cardiac extremity of the horse's stomach, sometimes gathering in considerable masses, until such time as, in the regular course of nature, they let go their hold, and are expelled through the intestines. They may be seen at times clinging to the edges of the amus, and the first impression of ignorance naturally is that the horse is doomed, and "going to the worms" before his time, but such is not by any means the case. Their history is this:

This kind of gadfly begins to fy in the latter half of the summer, and the natural instipct of the female is to deposit her eggs upon the hair of the nearest horse. If she cannot find one turned out to grass, she will hunt for him in thesstable, and no sort of defensive measures are of any avail except the removal of the lide of the horse. That done, and the danger is orer in that particular case. The fly selects those parts of the horse's coat in readiest reach of his tungue, and so glues her eggs on that they will not come off easily till softened by the saliva of the horse. Here they stay till the heat, aided by the tongue, causes the cggs to hatch, and then they aro licked off and swallowed, being about the size of a small "pin worm." Being swallowed, they. hitch themselves to the walls of their new home in the way we have described, and remain till the next spring. They are now, and for some time have been, as large as a bee grub, sometimes larger, and fulfill their destiny by passing out to become first each a chrysalis, and then a fly on his own account. The ordinary grooming of a well-stabled horse cleans the eggs off in time, especially as he is not likely to have many, but few horses in America get enough of stable care to keep them free.

The proper treatment is to let them alone until nature takes care of them, for they do not seem to do any great harm, and those medicines which will really kill the bots are equally dangerous to the horse. They are only a grub-bear. 


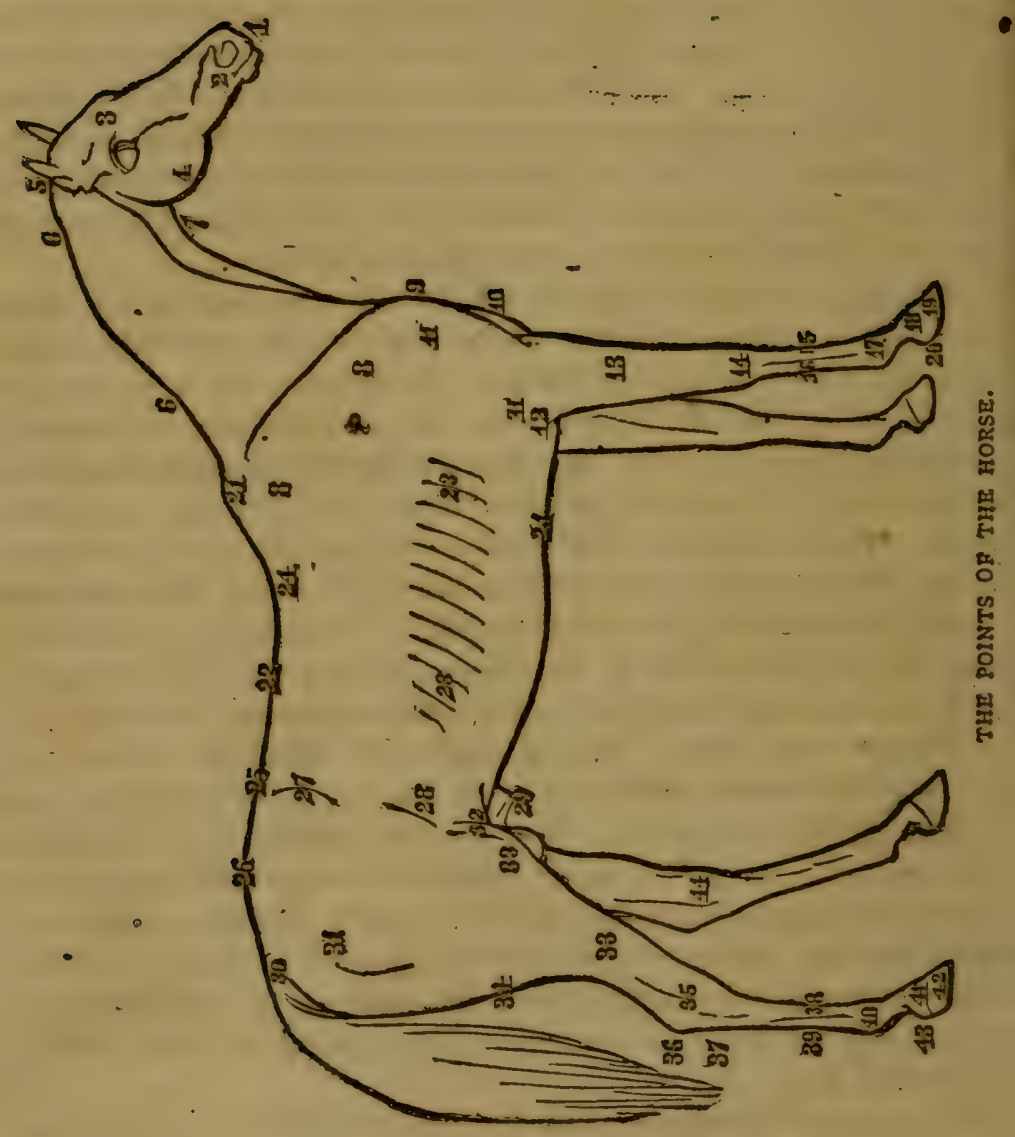


8. Muzzle.

HEAD.

2. Nostril.

3. Forehead.

4. Jaw.

5. Poll.

6. 6. Crest.

NECK.

7. Thropple or windpipe. FORE-QUARTER.

8. 8. Shoulder blade.

9. Point of the shoulder.

io. Biosom or breast.

II. xr. True-arm.

12. Elbow.

13. Forearm (arm).

14. Knee,

25. Cannon-bone.

16. Baek sinew.

17. Fetlock or pastern-joint.

18. Coronet.

19. Hoof or foot.

20. Heel.

BODY OR MIDDLEPIECE.

2r. Withers.

22. Back.
23. 23. Ribs (forming together the barrel or chest).

24. 24. The circumference of the chest at this point, called the girth.

25 The loins.

26. The croup.

27. The hip.

28. The flank.

29. The sheath.

3०. The root of the dock or tail.

THE HIND-QUARTER.

3r. The hip-joint, round, or whirl-bone.

32. The stifle-joint.

33. 33. Lowet thigh or gaskin.

34. The quarters.

35. The hock.

36. The point of the hock.

37. The curb place.

38. The cannon-bone.

39. The back sinew.

40. Pastern or fetlock-joint.

4x. Coronet.

42. Foot or hoof.

43. Heel.

44. Spavin-place. 


\section{CHAPTER NINETEENTH.}

DISEASES OF HORSES.

Inflammation of the bowels-Colic-Diarrheea and dysentery-Strangriation and hernia-Worms-Liver disease-Kidneys-Diabetes-Bladder, etc.

Veterixary surgeons describe various classes of inflammation of the bowels, but we may dismiss the entire mass of useless learning with this note, that the distinction can only be drawn with any certainty on cutting up the animal in case the attack kills him. The same kind of treatment is good for all, the main care being to be sure that you do not mistake your disease for colic, or vice versa.

The symptoms of inflammation of the bowels vary in severity and in the rapidity of their development, but they come on generally in about the following order: at first there is simple loss of appetite, dulness of eye, and a general uneasiness, which are soon followed by a slight rigor or shivering. The pulse becomes rapid, but small and wiry, and the horse becomes rery restless, pawing his litter, and looking back at his sides in a wistful and anxious manner. In the next stage all these signs are aggravated; the hind-legs are used to strike at but not touch the belly; and the horse lies down, rolls on his back and struggles violently. The pulse becomes quicker and harder, but is still small. The belly is acutely tender and hard to the touch, the bowels are costive, and the horse is constantly turning round, moaning, and regarding his flanks with the most anxious expression of countenance. Then comes the final and fatal stage, which is thus described by an English writer: "The next stage borders on delirium. The eyo acquires a wild, haggard, and unnatural stare-the pupil dilateshis heedless and dreadful throes render approach to him quite perilous, he is an object not only of compassion but of apprehension, and seems fast hurrying to his end-when all at once, in the midst of agonizing torments he stands quiet, as though every pain had left him and he were going to recover. His breathing becomes tranquillized-his pulse sunk beyond all perception-his body 
bedewed with a cold, clammy sweat-he is in a tremor from head to foot, and about the legs and ears has even a dead-like feel. Tho mouth feels deadly chill-the lips drop pendulous, and the eye seems unconscious of objects. In fine, death, not recovery, is at hand. Mortification has seized the inflamed bowel-pain can no longer be felt in that which a few minutes ago was the seat of most exquisite suffering. He again becomes convulsed, and in a few more struggles, less violent than the former, he expires." Tho whole duration of the attack being from twelve to forty-eight hours in acute cases, and extending to three or four days in those which are denominated subacute

Dr. Walsch says, in the treatment of this disease, as in all those implicating serous membrane, blood must be taken largely, and in a fuil stream, the quantity usually required to make a suitable impression being from six to nine quarts. The belly should be fomented with very hot water, by two men holding against it a doubled blanket, dipped in that fluid, which should be constantly changed, to keep up the temperature. The bowels should be backraked, and the following drench should be given every six hours till it operates, which should be hastened by injections of warm water:

\section{Take of Linseed Oil . . . . . . 1 pint. \\ Laudanum ...... $20 z$.}

If the first bleeding does not give relief in six or eight hours, it must be repeated to the extent of three or four quarts, and at the same time some liquid blister may be rubbed into the skin of the abdomen, continuing the fomentations, at short intervals, under that part which will hasten its operations. The diet should be confined to thin gruel or bran-mashes, and no hay should be allowed until the severity of the attack has abated.

To distinguish this disease from colic is of the highest importance, and for this purpose it will be necessary to describe tho symptoms of the latter disease, so as to compare the two together.

In colic there is spasm of the muscular coat of the intestines. Various names have been given to its different forms, such as tho fret, the gripes, spasmodic colic, flatulent colic, etc., but they all display the above feature, and are only modifications of it, depending upon the cause which has produced it. In spasmodic colic, the bowels are not unnaturally distended, but in flatulent colic 
their distension by gas brings on the spasm, the muscular fibres being stretched to so great an extent as to cause them to contract irregularly and with a morbid action. Sometimes, when tho bowels are very costive, irritation is established as an effort of nature to procure the dislodgement of the hardened facal matters, and thus a third cause of the disease is discovered. The exact nature and cause are always to be ascertained from the history of the case, and its symptoms, and as the treatment will especially be conducted with a view to a removal of the cause, they are of tho highest importance. The symptoms in all cases of colic, by which it may be distinguished from the last described disease, are as follows: In both acute pain is manifested by stamping, looking at the flanks, and rolling; but in inflammation of the bowels the pain is constant, while in colic there are intervals of rest, when the horse seems quite easy, and often begins to feed. In both the poor animal strikes at his belly; but in the former he takes great care not to touch the skin, while in the latter (colic) he will often bring the blood by his desperate efforts to get rid of his annoyance. In inflammation of the bowels the belly is hot and exquisitely tender to the touch, but in colic it is not unnaturally warm, and gradual pressure with a broad surface, such as the whole hand, always is readily borne, and generally affords relief. The pulse also is little affected in colic; and, lastly, the attack is very much more sudden than in inflammation.

Such are the general signs by which a case of colic may be distinguished from inflammation of the bowels, but beyond this it is necessary to investigate whether it is pure spasmodic colic, or produced by flatulence, or by an obstruction in the bowels.

Ir SPASMODIC colic all the above symptoms are displayed without any great distension of the abdomen; and if the history of the case is gone into, it will be found that after coming in heated the horse has been allowed to drink cold water, or has been exposed in an exhausted state to a draught of air.

Ir FLATULEXT coLIC the abdomen is enormously distended; the attack is not so sudden, and the pain is not so intense, being rather to be considered in the average of cases, as a high degree of uneasiness, occasionally amounting to a sharp pang, than giving tho idea of agony. In aggravated attacks, the distension is so enormous as to leave no doubt of the nature of the exciting cause. 
Hero also the spasms are often brought on by drinking cold water while the horse is in a heated and exhausted state.

Where there is a stoppage in the bowels to cause the spasm, on questioning the groom, it will be found that the dung for some days has been hard and in small-lumps, with occasional patches of mucous upon it. In other respects there is little to distinguish this variety from the last.

The treatment must in all cases bo conducted on a totally different plan to that necessary when inflammation is present. Bleeding will be of no avail, at all events in the early stages, and before the disease has gone on, as it sometimes will, into an inflammatory condition. On the other hand, stimulating drugs, which would be fatal in inflammation of the bowels will here generally succeed in causing a return of healthy muscular action. The disease is indeed similar in its essential features to cramp in the muscles of the human leg or arm, the only difference being that it does not as speedily disappear, because it is impossible to get at the muscular coat of the intestines, and apply the stimulus of friction.

As soon as a case is clearly made out to bo of a spasmodic nature, one or other of the following drenches should be given, the choice being made in proportion to the intensity of the symptoms :

1. Sulphuric Ether . . . . . . 1 oz.

Laudanum ... . . . . . . 2 "

Compound decoction of Alocs . . . . 5 "

Mix, and give every half hour until relicf is afforded.

2. Spirit of Turpentine . . . . 4 oz.

Linseed Oil . . . . . . . . 12 "

Laudanum ......... . . 11/2"

Mix, and give every hour till the pain ceases.

3. Aromatic Spirit of Ammonia .... 11/2 oz.

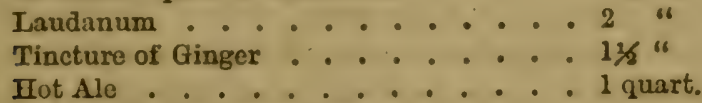

Mix, and give every hour.

Hot water should also be applied to the abdomen, and if an injection syringe is at hand, large quantities of water, at a temperature of $100^{\circ}$ Fahrenheit, should be injected per anum, until in fact the bowel will hold no more without a dangerous amount of force.

IN FLATULENT coltc the samo remedies may bo employed, but the turpentine mixture is hero especially beneficial. Tho use of 
warm water injections will often bring away large volumes of wind, which at once affords relief, and the attack is cured.

The administration of aperient medicines by the mouth of tho horse is only likely to increase the difficulty. Nothing but injections can be safely employed to relieve costive symptoms. An injection, in a bad case, of a gallon of gruel, containing a quart of castor oil, and half a pint of spirit of turpentine, may be useful, and half an ounce of laudanum may be given, in water, at the mouth, to relieve the spasms.

When the urgent symptoms of colic in any of its forms are relieved, great care must be exercised that a relapse does not take place from the use of improper food. The water should be carefully chilled, and a warm bran-mash should be given, containing in it half a feed of bruised oats. Nothing but these at moderate intervals, in the shape of food or drink, should be allowed for a day or two, and then the horse may gradually return to his customary treatment, avoiding, of course, everything which may appear to have contributed to the development of colic.

It will not be easy, in most cases, especially in their boginning, to distinguish between diarrhœa and dysentery, nor is it of any special importance. The difference in treatment is based more on the cause of the difficulty than on anything else.

When too much physic has been foolishly given, the organs of the horse are not unapt to obstinately refuse to reassume their natural operation.

When the action of the bowels has gone on for three or four days consecutively, and there is no disposition to "set," the eyes become staring and glassy, the pulse is feeble, and the heart flutters in the most distressing manner; the mouth has a peculiarly offensive smell, the tongue being pale and covered with a white fur having a brown centre. The abdomen is generally tucked tightly up, but in the later stages large volumes of gas are evolved, and it becomes tumid.

The treatment should consist in a feed of rice, boiled till quite soft, and if not taken voluntarily, it should be given as a drench, mixed into a thin liquid form with warm water. If the case is severe, one or two ounces of laudanum may be added to a quart of rice milk, and given every time the bowels act with violence. Or a thin gruel may be made with wheat flour, and the laudanum bo 
mixed with that instead of the rice. A perseverance in these remedies will almost invariably produce the desired effect, if they have not been deferred until the horse is very much exhausted, when a pint of wine may be substituted for the laudanum with advantage.

IN DIARRHEA resulting from cold, or over-exertion, the treatment should be exactly like that prescribed above, but it will sometimes be necessary to give chalk in addition to the remedies there alluded to. The rice or flour milk may be administered as food, and the following drench given by itself every time there is a discharge of liquid dung:

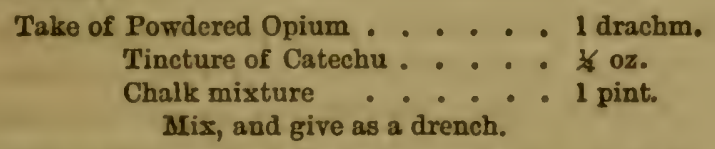

During the action of these remedies the body must be kept warm by proper clothing, and the legs should be encased in flannel bandages, previously made hot at the fire, and renewed as they become cold.

IN DYSENTERY (or molten grease) it is often necessary to take a little blood away, if there is evidence of great inflammation in the amount of mucous surrounding the dung, and when aperient medicine does not at once put a stop to the cause of the irritation by bringing the lumps away. Back-raking, and injections of two ounces of laudanum and a pint of castor oil with gruel, should be adopted in the first instance, but they will seldom be fully efficient without the aid of linseed oil given by the mouth. A pint of this, with half a pint of good castor oil, will generally produce a copious discharge of lumps, and then the irritation ceases without requiring any further interference.

Whenever there is diarrhœe or dysentery present to any extent, rice-water should be the sole drink.

The horse, like his human owner, is very apt a times to be troubled by worms, and these are not to be confounded with " bots." They are of two classes, of which the larger and more injurious are like ordinary "angleworms," except in their color, which is of a pinkish white. These latter have their peculiar field of operations in the smaller intestines, and the symptoms of their presence are not as clearly defined as it could bo wished. A rough, staring, hollow coat, a craving appetite without any seeming benefit from the 
food-for the animal grows thin on it all the while-and the passage of mucous with the dung, these are some of the ordinary indications of the presence of worms. Sometimes a small portion of the mucous will adhere to the anus, in its passage out, producing an itching sensation, which the animal tries to allay by rubbing with the tail, but such irritation may also arise from other causes. When these several symptoms are combined, it may with some degreo of certainty be supposed that there are worms in the intestines, but before proceeding to dislodge them, it is always the wisest plan to obtain proof positive of their existence, by giving an ordinary dose of physic, when on watching the evacuations, one or more worms may generally be discovered if they are present. When the case is clearly made out the plan of treatment is as follows:

Take of Tartar Emetic . . . . . . I drachm

Powdered Ginger . . . . . . . 1/4 " “

Linseed Meal sufficient to make into a ball with boiling water.

One should be given every morning for a week, then a dose of physic; linseed oil being the most proper. Let the stomach rest a week; give another course of balls and dose of physic, after which let the horse have a drachm of sulphate of iron (powdered) twice a day with his feed of corn.

There is no medicine which is so effectual for removing worms in the horse as tartar emetic, and none which is so entirely innocuous to the stomach. - Calomel and spirit of turpentine were formorly in use as vermifuges, but they are both dangerous drugs; the former, if given for any length of time, causing great derangement of the stomich and liver; and the latter often producing considerable inflammation after a single dose, if sufficiently large to cause the expulsion of the worms. Linseed oil given in halfpint doses every morning is also an excellent vermifuge, but not equal to the tartar emetic. If this quantity does not relax the bowels, it may be increased until they are rendered slightly more loose than usual, but aroiding anything like purgation.

The smaller specics of intestinal worm chiefly inhabits the rectum. It produces great irritation and uneasiness, but has not the same prejudicial effect on the health as the larger parasite. It is about ono to two inches in length, and somewhat smaller in diameter than a crow quill. The term thrcad worm is correctly applied to them, as they are not unlike sections of stout thread or cotion. 
The only symptom by which their presence can be mado out is the rubbing of the tail, when if on examination no vermin or eruption is found in the dock, it may be presumed that worms exist in the rectum. The remedy for these worms is by the injection every morning for a week of a pint of linseed oil, containing two drachms of spirit of turpentine. This will either kill or bring away the worms, with the exception of a few which are driven by it higher up, but by waiting a week or ten days (during which time they will have re-entered the rectum) and then repeating the process, they may generally be entirely expelled. The sulphate of iron must be given here, as before described.

\section{Dr. Walsch says :}

"The liver of the horse is less liable to disease than that of any other domestic animal, and the symptoms of its occurrence are so obscure that it is seldom until a post-mortem examination that a discovery is made of its existence. This unerring guide, however, informs us that the liver is sometimes unnaturally enlarged and hard, at others softened, and in others again the subject of cancerous deposits. It is also attacked by inflammation, of which the symptoms are feverishness; rapid pulse, not hard and generally fuller than usual ; appetite bad ; restlessness, and the patient often looking rouud to his right side with an anxious expression, not indicative of severe pain. Slight tenderness of the right side; but this is not easily made out satisfactorily. Bowels generally confined, but there is sometimes diarrhœa. Very frequently the whites of the eyes show a tinge of yellow, but anything like jaundice is unknown. The treatment must consist in the use of calomel and opium, with mild purging, thus:

Take of Calomel . . . . . . 1 drachm."

Powdered Opium ....... 1 "

Linseed Meal and boiling water enough to make into a ball, which should be given night and morning. Every other day a pint of Linseed Oil should be administered.

The diet should if possible be confined to green food, which will do more good than medicine; indeed, in fine weather, a run at grass during the day should be preferred to all other remedies, taking care to shelter the horse at night in an airy loose box.'

THE KIDNEYs aro particularly prone to disense, and are subject 
to inflammation; to diabetes, or profuse staling; to hæmaturea, or a discharge of blood, and to torpidity, or inaction.

INFLAMMATION OF THE KIDNEXS is generally produced by an exposure of the loins to wet and cold, as in carriage-horses standing about in the rain during the winter season. Sometimes it follows violent muscular exertion, and is then said to be caused by a strain in the back, but in these cases there is probably an exposure to cold in a state of exhaustion, or by the rupture of a branch of the renal artery or vein, as the inflammation of one organ can scarcely be produced by the strain of another. The symptoms are a constant desire to void the urine, which is of a very dark color-often almost black. Great pain, as evidenced by the expression of countenance and by groans, as well as by frequent wistful looks at the loins. On pressing these parts there is some tenderness, but not excessive, as in rheumatism. The pulse is quick, hard, and full. The attitude of the hind quarters is peculiar, the horse standing in a straddling, position with his back arched, and refusing to move without actual compulsion. It is sometimes difficult to distinguish this from inflammation of the neck of the bladder, but by attending to the state of the urine, which is dark brown or black in the former case, and nearly of a natural color in the latter, the one may be known from the other. To make matters still more clear, the oiled hand may be passed into the rectum, when in kidney disease the bladder will be found coatracted and empty (the urine being so pungent as to irritate that organ), while in inflammation or spasm of its neck, it will be distended, often to a large size. The treatment to be adopted must be active, as the disease runs a very rapid course, and speedily ends in death if neglected. A large quantity of blood must at once be taken. The skin must be acted on energetically, so as to draw the blood to its surface, and if a Turkish bath is at hand, it will be highly beneficial. If not, the application of hot water, as recommended on page 165 , may be tried, and in many cases it has acted like a charm. Failing the means for carrying out either of these remedies, the loins should be rubbed with an embrocation consisting of olive oil, liquid ammonia and laudanum in equal parts, but - cantharides and turpentine must be carefully aroided, as likely to be absorbed, when they would add fuel to the fire. A fresh sheepskin should be warmed with hot (not boiling) water, and applied over 
the back, and the liniment should be rubbed in profusely every hour, restoring the skin to its place immediately afterwards. Mustard is sometimes used instead of ammonia, and as it is always at hand, it may form a good substitute, but it is not nearly so powerful an irritant to the skin as the latter, especially when evaporation is prevented by the sheepskin, or by a piece of any waterproof article. A nild aperient may be given, linseed oil being the best form, but if the bowels continue obstinate, and it is necessary to repeat it, eight or ten drops of croton oil may be added to a pint of the oil, great care being taken to assist its action by raking and injection, the latter being also useful as a fomentation to the kidneys. The diet should consist of scalded linseed and bran-mashes, no water being allowed without containing sufficient linseed tea to make it slightly glutinous, but not so much so as to nauseate the patient. If the symptoms are not greatly abated in six or eight hours, the bleeding must be repeated, for upon this remedy the chief dependence must be placed. A mild and soothing drench, composed of half an ounce of carbonate of soda, dissolved in six ounces of linseed tea, may be given every six hours, but it is of no certain effect. Unless the inflammation subsides the horse will dio in a few hours.

DrabETES of late years has been much more frequent than was formerly the case, probably owing to the enormous quantities of corn which are allowed in the present day. But whatever may be the cause, the symptoms are clear enough, the horse constantly staling and passing large quantities of urine each time. The treatment should be condusted on the principle that the cause should if possible be ascertained and removed. Mowburnt hay will often bring on diabetes, and new oats have a similar tendency in delicate horses. In any case it is wise to make a total change in the food as far as it can possibly be done. Green food will often check it at once, and a bran-mash containing a few carrots has a similar chance of doing good. With these alterations in the quality of the food attention should also be paid to the quantity of the grain, which should be reduced if more than a peck a day has been given: IIalf a drachm of the sulphate of iron (powdered) should be mixed with each feed (that is four times a day), and the horse should be well clothed and his legs warmly bandaged in a cool and airy stall or box. By attention to these directions the attack may generally. 
bo subdued in a few days, but there is always a great tendency to its return. Should it persist in spite of the adoption of the measures already recommended, the following ball may be tried :

Take of Gallic Acid . . . . . $1 / 2 \mathrm{drachm}$.

Opium ...... 1 drachm.

Treacle and Linseed Meal enough to make into a ball, which should be given twice a day.

Hematurea, like diabetes, is easily recognized by the presence of blood in greater or less quantities passed with the urine. It is not, however, of the bright red color natural to pure blood, but it is more or less dingy, and sometimes of a smoky-brown color, as occurs in inflammation. Bloody urine, however, may often be passed without any sign of that condition, and therefore unaccompanied by pain, or any other urgent symptom. The causes are exceedingly various. The symptoms are the existence of bloody urine unaccompanied by pain or irritation, marking the absence of inflammation of the kidneys. As to treatment, little can be done in severe cases, and mild ones only require rest, a dose of physic, and perhaps the abstraction of three or four quarts of blood. Green food should be given, and the diet should be attended to as for diabetes. If the urine is scanty, yet evidently there is no inflammation, two or three drachms of nitre may be given with the mash at night, but this remedy should be emplojed with great caution:

INACTION OF THE KIDNEYS is common. Very often the kidneys are only inactive because the horse has not been regularly watered, and where an unlimited supply is allowed this condition is comparatively rare. There is no harm in resorting to nitre occasionally, but if it is often found necessary to employ this drug, the health is sure to suffer, and an alteration in the diet should be tried in preference. At all events, if it is given, the horse should be allowed to drink as much and as often as he likes.

THE BLADDER is subject to inflammation of its coats or neckto spasm-and to the formation of calculi.

INFLAMMATION OF THE BLADDER is not very common excepting when it is produced by irritants of a mechanical or chemical nature. Thus when the kidneys secrete a highly irritating urine, the bladder suffers in its passage, and we have the two organs inflamed at the same time. Again, when cantharides have been given, the bladder is liable to become inflamed. The symptoms 
are-a quick pulse-pain in the hind-quarter, erinced by tho looks of the animal in that direction-and constant straining to pass the mrine, which is thick and mixed with mucous, or in aggravated cases, with purulent matter. The treatment to be adopted, if the case is severe, will consist in bleeding, back-raking, and purgation with linseed or castor oil, avoiding aloes, which have a tendeucy to irritate the bladder. Linseed tea should be given as the solo drink, and scalded linseed mixed with a bran-mash, as food. Tho following ball may also be given, and ropeated if necessary :

Take of Powdered Opium . . . . 1 drachm. Tartar Emetic . . . . 11/2 drachms.

To be made up into a ball with linseed meal and boiling water, and given every six hours.

RETENTION OF URINe may be due either to inflammation of the neck of the bladder, occasioning a spasmodic closure of that part, or there may be spasms unattended by inflammation, and solely due to the irritation of some offending substance, such as a calculus, or a small dose of cantharides. The treatment, in either case, must be directed to the spasmodic constriction, which is generally under the control of large doses of opium and camphor, that is, from one drachm to two drachms of each, repeated every five or six hours. If the symptoms are urgent, bleeding may also be resorted to, and when the bladder is felt to be greatly distended, no time should bo lost in evacuating it by means of the catheter, which operation, howerer, should only be entrusted to a regular practitioner accustomed to its use.

BaLANITIS, or inflammation of the penis, is very common in tho horse, being brought on by the decomposition of the natural secretions, when they have been allowed to collect for any length of time. At first there is merely a slight discharge of pus, but in process of time foul sores break out, and very often fungus growths spring from them, which block up the passage through the oprening of the sheath, and causo considerable swelling and inconvenience. These are quite distinct from warts, which occur in this part just as they do in other situations. The treatment requires some skill and experience, because mild remedies are of no use, and severe ones are not unattended with danger. The parts first of all must be well cleansed by syringing, or if the end of the po- 
nis can be laid hold of, by washing with a sponge. The following wash may then be applied, and it should be repeated every day:

Take of Solution of Chloride of Zinc. . . . 2 drachms.

Water ......... 1 pint. Mix.:

If the morbid growths are very extensive, nothing but amputation of the penis, or the use of corrosive sublimate will remove them. Severe bleeding sometimes follows both of these measures, but it scldom goes on to a dangerons extent. Still it is scarcely advisable for any one but a professional man to undertake the operation.

In the mare the vagina is sometimes inflamed, attended with a copious yellow discharge. An injection of the wash mentioned in.the last paragraph will generally soon set the matter right. At first it should be used only of half the strength, gradually increasing it, until the full quantity of chloride of zinc is emplojed.

IN VERSION OF THE UTERUS sométimes follows parturition, but it is very rare in the mare. The uterus should be at once replaced, using as little force as possible, and taking care before the hand is withdrawn, that it really is turned back again from its inverted position.

NYMPHOMANIA occurs sometimes in mares at the time of being "in use," and goes on to such an extent as to render them absolutely regardless of pain, for the time being, though not to make them lose their consciousness. They will kick and squeal till they become white with heat, and no restraint will prerent them from trying to continue their violent attempts to destroy everything behind them. These symptoms are especially developed in the presence of other animals of the same species, whether mares or geldings; but the near proximity of an entire horse will be still worse. If placed in a loose box, without any restraint whatever, they generally become more calm, and when the state is developed, such a plan should always be adopted. It is chiefly among highly-fed and lightly worked mares that the disease is manifested; and a dose of physic, with starvation in a loose box, away from any other horse, will very soon put an end to it in almost every instance. 


\section{CHAPTER TWENTIETH.}

\section{MISOELLANEOUS DISEASES.}

Convulsions-Mad staggers-Madness-Megrims-String-halt-SunstrokeStomach staggers-Lockjaw-A poplexy.

Convolsioss, properly so-called, are almost entirely confined to young colts, and constitute a "pasture disease" or summer complaint. Very little is known about them, or can be done for them. They are variously attributed to heat and worms. The attacks are generally brief, the sufferer falling to the ground without much warning, and kicking violently, and then in a few minutes getting up, apparently as well as well as ever. A mild dose of linseed oil may prevent a second attack, or it may not, but il will do no harm to try the experiment.

Good veterinarians differ both as to the causes and nature of the rare but fatal disease known as MAD STAGGERs, and some have had much to say of its treatment. As to this latter, inasmuch as we have never known a case in which treatment was of any use, we will only say that humanity calls for a bullet through the animal's head, as soon as the true nature of the disease is definitely ascertained, and devote our attention to such a description of the symptoms as to prevent any error.

Youalt describes the mad staggers as a species of brain fever, and that, no doubt, is sufficiently accurate. The first symptoms are not such as to give any indication, to an inexperienced eye, of what is coming. The eyes will be heary, and the horse will reject his food, but that is about all. After a day or two, sometimes three, the fever suddenly shows itself more acutely, and delirium comes on. The flanks will heare, the nostrils aistend, and the unfortunato brute will dash himself furiously about, kicking, biting and plunging. He seems to be bent on mischief, but is more likely blindly unconscious of all but his sufferings. He will dash himself to pieces, sometimes, if not checked. He must by all means be kept penned up, or he will be sure to do harm. Severe bleeding will make him quiet from exhaustion, but except it may be in very mild 
cases, it will do no permanent good. He may even pass out of his first fit into a state of stupor, for the disease is a varying and treach-

\section{- erous one.}

$N_{c}$ (he with any coolness or judgment need mistake the pain and distrens of colic for the disease, though it has been done in some cases. In genuine madness, though the results and treatment are about the same, the symptoms differ. Both being incurable, we may classify and describe them together. Madness is never primarily developed in the constitution of any horse, but must always come, in some manner, from an animal of the dog or cat kind. If a mad dog has been in the neighborhood, that fact will assist in understanding the symptoms, but if these latter are sufficiently marked, no time need be wasted in hunting for the dog, as the effects of the virus require from three to eight weeks before they show themselves. At once on the appearance of any signs of madness, such measures should be taken as will absolutely prevent the animal from doing mischief, in any event, to any other living thing. In case of a mistake in the disease no harm will be done, and if there is no error' the horse can be killed before he has communicated the fearful malady, or inflicted other damage in his paroxysms. Dr. Walsch and others erroneously declare that horses taken with madness always show the same fear of water, and the like, that causes the discase to be termed hydrophobia in other animals, and thus might lead to dangerous mistakes. On the contrary, even when there is dread of liquids, the thirst produced is sometimes excessive, although swallowing is performed with painful and difficult gulps. The attack is apt to come with very little if any" warning. The horse may go to his work as usual, and suadenly stop in his traces, tremble, heave, paw, stagger and fall; then he will rise again as if to go on, look wildly about him, give a frantic pull or two, and then again go down. No time is to be lost. If the case is otherwise a clear one, destroy him at once. If thero is any reasonable doubt, get him confined as quickly as possible in the nearest secure place, or you do not know for what evil you may be responsible. Theareneral symptoms have been better described by Youatt than by anybody else, for fortunately madness is not common. He says that it begins with "a spasmodic movement of the upper lip, particularly of the angles of the lip. Closely following on this, or contconporaneous with it, are the depressed and anxious 
countenance and inquiring gaze, suddenly, hotrerer, lighted up and becoming fierce and menacing from some unknown cause, or at the approach of a stranger. From time to time different parts of the frame, the eyes, the jaws, particular limbs will be convulsed. The eye will occrsionally wander after some imaginary object, and the horse will snap again and again at that which has no real existence. Then will come the irrepressible desire to bite the attendants, or the animals within its reach. To this will succeed the demolition of the rack, the manger, and the whole furniture of the stable, accompanied by the peculiar dread of water which has already been described. Towards the close of the disease there is generally paralysis, usually confined to the loins and hinder extremities, or involving those organs which derive their nervous action from this portion of the spinal cord: hence the distressing tenesmus which is occasionally seen."

The main difference to be noted between genuine madness (rabies), and bad cases of mad staggers is, that in the latter, the victim seems to lose all fear of man, if not all consciousness of his presence, while the mad horse, however savage and destructive, will know his master, and exhibit other signs of "horse sense," even amid his sufferings.

The best reterinary authorities lead us to believe that the external symptoms known as MEGRIMs may be indications of raried forms of disease of the brain or heart of the horse, but whose precise nature can only be ascertained by that last resort of scientific curiosity, a post-mortem examination. All the purposes of this book will, therefore, be answered by briefly indicating the disease and its treatment.

The horse is perhaps trotting along, when all at once he begins shaking his head as if the bridle chafed his ears, which are drawn back close to the poll. The driver gets down to examino these facts, and observes the eyelids quivering, and the nostrils affected with a trembling kind of spasn. Sometimes the rest will allow of the attack going off, but most frequently, the head is drawn to one side, the legs of that half of the body seem to be paralyzed, and the horse making a segment of a circle goes down, lies a few minutes on the ground, and then rises as if nothing had happened beyond a slight sweating and disturbance of the respiration. Treatmont can be of little avail. If the attack has happened while 
in harness, the collar should always be carefully inspected, and if at all tight it should be replaced by a deeper one. A diseased state of the valves of the heart ought to be discoverable by auscultation, but it requires a practised ear to do this, and the directions for ascertaining its presence are beyond the scope of this book. The only plan which can be safely adopted, is to take the subject of megrims quietly home to his stable, and carefully examine into the condition of all his functions, with a view to improve the action of any organ which appears to be out of order, whatever it may be. If all seems to be going on well-if the appetite is good, and the heart acts with regularity and with due force, while the brain seems clear, and the eye is not either dull or suffused with blood-nothing should be attempted, but the horse being subject to a second attack, as proved by experience, should be put to work in which no great danger can be apprehended from them.

Tetanus, or lockjaw, is not a very common thing, and may generally be recognized by the rigidity of the lower jaw and the muscles of the neck. The head is stretched out and turned to one side, the nostrils are dilated, the eyes drawn back, the ears stiff and erect. Gradually, the whole body, to the very tail, becomes affected in a similar manner. The horse evidently suffers great pain., The disease is a treacherous one, but something may be done by prompt and severe treatment. If the "dilute Prussic acid " of the U. S. Pharmacopœia is obtainable, which it seldom is, give thirty drops night and morning, and keep the animal in a quiet place. This must be given at once to be of any service. Chloroform, however, can almost always be got at, and this must be carefully administered, through a flannel cloth, guarded by a piece of "sieve wire" to keep the chloroform from dripping on the lips and mouth. A little ingenuity and skill will force the horse to breathe through the wire, and inhale the chloroform. Keep it up until the horse does not feel the prick of a pin, and the spasm will probably be relieved temporarily, so that other medicines can act. Then blister the whole length of the spine with tincture of cantharides, and give a pint of castor oil and six or eight drops of croton oil. If this cannot be got down him, try two drachms of calomel, and as much of tartar emetic. Use all means to get them into the mouth, 
and to force him to swallow them. If you can get the bowels to operate copiously, give two drachms of solid opium, or what is better, repeat the chloroform in about six hours, keeping the horse under its influence for an hour or two, according to the severity of the case, and withdrawing it slowly.

Do not attempt any quack remedies for the proposed cure of STRINGIILT, as nothing can be done for it.

Sunstroke is a rery common disease, in our large cities especially, and is best prevented by regular and frequent watering, care not to over-feed or over-work, and a small pad or shade fastened on the headstall so as to not touch the head. The latter is not needed unless the horse is to be much exposed.

In case of an attack, take the animal into the shade. If you can get ice, pound it small, wrap it in a cloth and pack it on his forehead and between his ears. Give him two ounces of sulphuric ether and 20 drops of tincture of aconite and a quart of ale or porter. Do not use him again until he is entirely recovered, and remember that he is doubly likely to be attacked again.

The first symptoms of sтомАсн sTAGGERs closely resemble those of mad staggers, but the effects are not always so fatal. It is the result of over-feeding, or too heavy a feed after too long a - fast, and this fact is a sufficient suggestion of the best mode of prevention. The symptoms are: the horse stands dull, sleepy, staggering; when roused, he looks vacantly around him; perhaps seizes a lock of hay, and dozes again with it in his mouth; at length he drops and dies; or the sleepiness passes off, and delirium comes on, when he falls, rises again, drops, beats himself about, and dies in convulsions.

"Bleed very largely; - that cannot do harm, and in mad staggers is indispensable. Gire a good dose of physic-that also cannot do harm, although in stomach staggers it cannot do much good, for it can scarcely find its way into the over-distended stomach, and it certainly cannot find its way through it. Keeping the horse from all food will be a very proper proceeding, whichever be the disease." So says Youatt, and we may add that if you can get and use a stomach pump, and relieve the poor beast of that which is poisoning him, you may do better still.

In a case of APOPLEXY it will not be often that you will know 
what is the matter until it is too late. Bleeding copiously, severe purgation, and blisters to the head and neck, are the only treatment and will probably fail. A marked symptom is great sleepiness, accompanied by snoring and a heavy stupidity in the swing of the head. 


\section{CHAPTER TWENTY-FIRST.}

Diseases of the ear-Diseases of the eye-Cataract-Buckeje-Simple inflammation - Epidemic ophthalmia - Specific ophthalmia - Surfeit Mange - Mallenders - Seratches-Founders-Navicular disease-Overreach.

THERE is but one disease of the horse's EAn to which we need allude. When deafness is occasioned by the formation of an abscess, from any cause, wait for the proper time, open the abscess so, that the matter will flow out as fast as it forms, and leave the caso to nature.

The EYE of the horse is very liable to various diseases, and for some of them treatment is very effective. Nothing can be done for CATARACT or BUCKEYE, and humanity forbids that anything should be attempted. They are local in their nature and do not depend upon or affect the general health of the horse.

Srmple ixflamation may be a disease by itself, or a symptom of something worse, but should receive prompt attention. It is easily recognized by the half-shut eye, afraid of the light; the gummy, sticky lids; the formation of "tears;" the redness inside the lidis, and the swollen, bloodshot look of the eye itself. It may te caused by local injury, a bad cold, or orer-feeding, and if it is not checked it may destroy the eje.

In bad cases bleed from the jugular vein very freely; gire a good dose of physic; bathe the eyo frequently in warm water or weak tea; in a very severe case put a seton into the skin of the up) per jaw, two inches below the eye. This latter, however is only for bad cases, and should not be tried in a hurry. Mild cases will do well with the physic and without bleeding. Another treatment, for ordinary cases, consists of cold water bandages, washing several times a day with cold tea, and a careful touching of the insiclo of the lid twice a day with a soft camel's hair brush dipled in a weak solution of nitiate of silver, 12 grains to four ounces of raiu water. If the inflammation is taken in its very first stages a judicious employment of these simple remedies will geverally ef- 
fect a cure. Bear in mind that over treatment will do for your horse's eye just what it would for your own.

Epidemic ophthatmia is only too common in some parts of the country, and most horse owners know the symptoms. One of these is a free discharge of purulent fluid, and the eyelid becomes much swollen, while the eye seems covered with a puffy red membrane.

Begin, at first, as for simple inflammation, but if the disease has got into the chronic stage, double the strength of the nitrate of silver wash, and use a quill in getting it into the eye. A few drops once a day will be sufficient.

SPECIFIC OPHTHALMIA is the worst disease to which the eyes of horses are liable, is swift in its action, difficult to cure and likely to return. Even if the eye is "cured" it is generally injured in some way. It is an inflammation of the iris or colored part of the eye. The symptoms are, the "white" of the eye becomes of a deep red, the cornea has a muddy look, the iris loses its brightness and often shows one or two white specks, while light seems to be unendurable.

Bleeding, purging, and the seton, as before described, are the only remedies, but they must be set promptly at work, or not only will this eye be surely gone, but the other will be in danger. In any of these diseases, low feed, little corn, quiet, plenty of fresh air and freedom from dust and other irritants, must be looked out for as matters of course. If the eye has been injured by an accident, proceed with warm water fomentations and a bandage, precisely as if it were your own.

Amadrosis, or palsy of the retina, if caused by a disordered stomach, will sometimes yield to a good run at grass. Bleeding and a seton, as above, in bad cases, are not without effect, but when that is required the disease is generally incurable. The symptoms are, deficient or absent sensibility to light, and a consequent indisposition of the pupil to contract, while the latter maintains also an unnatural expansion. This should be carefuliy looked for in buying a horse.

SURFEIT shows itself in small scabs on the back and loins, matting the hair. It indicates simply a bad condition of the blood and deficient action of the skin in carrying off secretions, and may be caused by various errors in feeding and stable care. In treat- 
ing it, adopt only such a course as is best calculated to bring the horse into good condition, without reference to the disease, or at most give him an occasional mild dose of nitre to act on his kidneys. The cure must be left to time, and all sharp remedies aroided.

HrDEBound, a dry, tight skin, that seems too small for the horse, is a symptom and consequences of other diseases, or is caused by bad food and derangenent of the digestive organs. All the treatment must be directed to the other diseases, if known, and to promoting healthy and regular action of the stomach and bowels. No horse will be hidebound while these latter work well.

MANGE is simply "horse itch," and is of the same cause and character with the human disease. The treatment must aim at killing the itch insect and preventing its return. The stable and everything the horse touches must be thoroughly washed with a solution of spirits of turpentine. Nothing but a washing in a solution of corrosive sublimate will safely cleanse the harness. For the horse the following recipes are commonly in use, and may be regarded as sufficient:

1. Take of Common Sulphur ...... 60 oz.

Sperm or Train Oil :. . . 1 pint.

Spirit of Turpentine . . . . $3 \mathrm{oz}$.

Mrix, and rab well into the skin with a flannel, or in preference with a painter's brush.

2. Take of Compound Sulphur Ointment . $8 \mathrm{oz}$.

Train or Sperm Oil ...... 1 pint.

Spirit of Turpentine …. $3 \mathrm{oz}$.

Mrix, and use as above.

Mallexders and sallenders are both of the same nature, differing only in the locality where they are displayed. The former shows itself in the flexure at the back of the knee, and the latter at the bend of the hock. The symptoms are shown in the appearance of a foul scurf mixed with a few thin scabs, the skin underneath being stiff and unyielding. They are generally brought on by washing the legs and leaving them undried. The treatment required is merely the application of the following ointment, which should be well rubbed in every night:-

Take of Cerate of Superacetate of Lead . $1 \mathrm{oz}$.

Creosote ....... 10 drops.: 
If the skin continues to be very hard and stifi, a little glycerine should be brushed on two or three times a week.

WARBLES, SITFASTS, IARNESSGALLS, and other local evidences of too much friction and pressure, are best cured by rest, gentlo fomentations, and an application of arnica liniment. Many other common liniments, to be had every where, will answer the purpose of keeping the parts soft and stimulating natural action.

SWELLED LEGS will come to almost any horse on being changed from pasture to stabling, and in that case will disappear with use. Other horses have it in a chronic form every morning, the swelling going off as they are worked in. Too long standing on hard floors, or a general weakness, may also cause swelling. . In any case the treatment must be guided by the cause. When the weak horse gets stronger his legs will get well, and no medicine will strike at them directly. Bandages and bathing, with gentle ubbing, are the only local applications, but in any case exercise is desirable.

CHAPPED IEELS, the skin cracking and exuding a watery eruption, are very common consequences of careless stabling in bad weather. Rub in cerate of acetate of lead every night, to make the skin soft and keep it from cracking, and in the morning rub in common gljcerine before taking the horse out.

Scratcres is a worse form of chapped heels, and is peculiarly common in the prairie countries. The discharge itself then becomes foul, acrid, offensive, and spreads. the disease. The treat. ment is simple. Cut off the hair over the diseased part, and wash thoroughly in warm soapsuds. Rinse well and dry, and then gently apply a very mild solution of chloride of zinc. Begin with thirty grains to a pint of water, but make it stronger for chronic or obstinate cases. Half an hour afterwards gently rub in glycerine. Keep up this treatment, and from time to time scrape or cut away the dead matter that will be left. With some horses the disease becomes constitutional and keeps breaking out afresh. In such cases the surgeons advise a wineglass full of liquor arsenicalis, given with the food twice a day for eight or nine weeks, as a specific.

CORNS $\triangle N D$ SANDCRACK, generally the consequences of bad shoeing and subsequent neglect, require, in the first place, long rest, for a cure, and in the second a shoe especially adapted to the individual case, and which can only be devised and fitted by a 
competent farrier. Such directions as we could give, or as aro ordinarily given in popular works on farriery, will neither aid nor dispense with the skill of the "expert."

Quitron is a chronic abscess in the foot caused by some external bruise or other injury. It is indicated by an opening in the horn, emitting a foul discharge. The sore must be probed and a way made for the pus to come out, but here again it will be necessary to call in the aid of practical experience.

THRUsI is an offensive dischargo from the frog. If caused by a damp stable floor, or standing too much in a yard choked with manure, that treatment must be promptly reversed, and the softening of the part further checked by an application of tar ointment. If then the decomposition does not stop, or the hoof dry and harden, wash it daily in a solution of chloride of zinc, fivo grains to an ounce of water.

If the thrush is a simple inflammation of the sensible frog, and a spongy substance is deposited instead of horn, the frog will look uneven and ragged, breal away in places, have a greasy surface, smell foul and feel hot. The cause is here internal as well as external. Give a dose of physic, reduce the food, give very little corn, exercise the horse, keep the feet and the stable clean and dry. Then keep on a bran poultice several days, until the inflammation subsides. After this use tar ointment or solution of chloride of zinc, as prescribed above.

Dr. Walsch describes a third kind of thrush and its treatment, thus: "It occurs in contracted feet, and is due to chronic inflam-. mation of the sensible frog, produced by overwork, aided in many cases by neglect in shoeing. There is a tendency to tho secretion of unsound horn over the whole foot, sometimes too thick and hard, and at others of a cellular structure, without sufficient strength to bear the pressure of the road. The horny frog gencrally looks shrunken and withered; and in its cleft there is a foul discharge, on wiping out which a soft spongy matter may be seen at the bottom, which is the sensible frog itself, but in a diseased condition. In bad cases, the sides of the horny frog have separated, and even the toe is sometimes deficient of its covering; but gencrally the horn has-only disappeared in patches, and there a!o ragged portions remaining. The disease here is of too chronic a nature to be easily cured, and if there is much disorganization of 
the laminx it will be almost impossible to effect a perfect cure, The first thing to be done is to clear away all the ragged portions of horn, so as to be able to reach the sensible frog. Some tow is then to be smeared with the following ointment :-

Take of Ointment of Nitrate of Mercury $\ldots 11 \mathrm{drachm}$.
Zinc Ointment
Creosote

and pressed into the cleft of the frog, where it can best be retained by a bar-shoe lightly tacked on, and in this case taking its bearing on the heels and not on the frog. Sometimes a wash answers better than a greasy application, and then a strong solution of the chloride of zinc may be employed, about six grains to the ounce of water. Tow dipped in this may be applied in the same way as with the ointment, and either one or the other should be re-applied every day. As the new horn grows, it must be kept supple by tar ointment, and until it is fully developed, the bar-shoe should be kept on, applying some degree of pressure by means of the tow, which should be stuffed in so as to compress the frog, beginning with very light pressure, and, as the horn increases in substance, augmenting it in proportion. By attention to these directions a thrush of this kind may be cured, if the foot is not damaged throughout, and even the frog may be restored to a comparative state of health."

FOUNDER, or fever of the feet, called by the surgeons "laminitis," is only too common. It is either an acute or chronic inflammation of the parts between the crust or wall of the hoof and the pedal bone, and these parts are so full of blood vessels that when once the disease starts it grows rapidly. The causes are-any fever "settling" in the feet; severe use on hard roads; long standing on a hard floor.

It is a treacherous disease in its chronic form, and often goes on without being noticed until the horse is ruined. When "acuts laminitis" sets in, there will be the usual signs of fever; quick, strong pulse ; hurried respiration, with restlessness as if from pain; the horse tapping the ground lightly with his feet, lying down and getting up. If the founder is only in the forefeet, and this is usual, the horse will throw all the weight he can on his hindfeet. He will object to having his hoofs taken up, and they will feel very hot. If something is not promptly done, the animal has lost his useful- 
ness. Removo the shoe, pare down the sole, so. as to permit internal expansion, and bleed copiously from the toe. Next tack the shoes on lightly again, and then give a smart dose of physic, or else, what is perhaps a better plan, give the following:

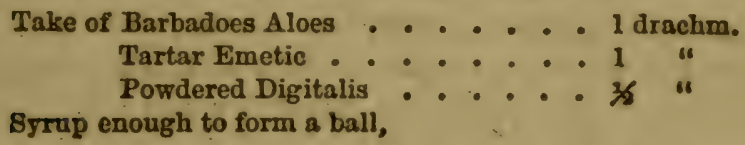

which should be given every six hours, until the bowels act, when the other materials may be continued without the aloes. The feet should be kept constantly wet and cool, by tying a piece of felt or flannel around each pastern, and allowing it to fall over the hoof, when it is to be continually wetted. If the inflammation is not abated next day, the bleeding may be repeated, and it will be well also to act on the kidneys by adding two or three drachms of nitre to the tartar emetic and digitalis.

Tho chronic form of this disease is, as has been said, treacherous, coming generally in buth forefeet at once, so that the horse does not faror either one especially, and careless eyes, do not discover the difficulty. On coming in from work a heated feeling will be found at the coronet, but this goes off during the night. After a month or so, the nails of the shoe do not hold so well, and the quarters break away, while the horse becomes shambling in his action. He will not go well on a hard road, or under the saddle, though he may go well enough on a soft road, or in harness. He will exhibit a disposition to save the toes of his forefeet, and this will give him a very low and shambling movement. This will catch experienced eyes at once, and any one may take "founder" for granted, when he sees a horse carefully putting his heels down first, with a low action. The best preparation for such a detection will be the continued study of the action, and "foot fall" of sound and active horses. The outer shape of the hoof undergoes a change after awhile, but not until the disease has advanced beyond cure. The sole, howerer, is always flatter than usual, or it may even present a "bulged" appearance, while the horn of the hoof becomes brittle and spongy. This latter makes what is known as "pumiced foot." The frog becomes unnatually large and spongy. The effect of the disease is to throw the whole weight of the horse on the parts below the coffin-bone and navicular-bone. 
For cases of long standing very little can be done in the way of a cure, though the disease may be so got under control that the animal is worth something for some kinds of work.

Do not bleed the foot unless there is marked inflammation that cannot be otherwise reduced. Keep the horse from all heating food, and allow him as small a ration of oats as is consistent with keeping up fair condition. Keep the stable dry and cool, give an occasional bran-mash, with nitre, and now and then a mild dose of physic, to keep down inflammation, apply cooling devices to tho feet after any work or exercise, and avoid hard roads, or any fast or pounding work. In this way, a horse not badly foundered may not only be made very useful, but will be likely to improve. If the frog is not very prominent, a leather sole may save it some of the jar, but if it is, the sole must be put in between the foot and the shoe, and have a hole cut in it to the shape of the frog, so as not to bear on it. If the case is not a bad one, the horse may work with such a contrivance for several years.

If the animal seems disabled, give him soft tan or sawdust to stand on, take off his shoes, blister his coronets two or three times, and do not so much as "walk him over hard ground for six months. Then, if he is improved, get him into work again very gradually. He will never again be a reliable road horse, but for farm work, or over turf roads, he may do tolerably. well.

SEEDY TOE, as it is called, is only one stage and consequence of laminitis, and calls for about the same treatment, but very littlo improvement can be hoped for.

Coniraction of THE PEET, unless found in connection with actual disease, is a humbug. An examination of the next mule or donkey you may meet will convince you that an animal may have his hoofs in that shape, and never know what disease is.

NAVICUlar DISEASE, or joint lameness, may come to the best made foot, for it is a "farrier's disease," and generally the result of bad shoeing and hard battering.

The symptoms vary somewhat, but there it always more or less lameness, and it generally comes in both feet at once, so that it may be carelessly overlooked, as in founder. The particular sign is the forward pointing of the toe, and a peculiar rounding forward of the fetlock-joint, in an effort to relieve tlie navicular-bone of any weight. In the stable, if both feet are affected, the horse will 
point forward first with one and then the other, clearly showing his rlistomfort, and out of doors, the toes will dig into the ground, so . that a sufferer from this disease is almost always a stumbler. Ho will nerertheless walk very well, but the moment he is trotted, his shortened gait will tell of him.

Various remedies for recent cases aro proposed by different writers, but they are such as require an experienced hand, except that advantage may be gained by standing the horse, daily, for two or three hours, in yielding clay, to lead him to let himself down more on his heels, and givo a better chance for naturo to work in restoring the injured parts. There is one resourco which may seem cruel, but which is often the only thing left, and which will generally restoro the animal to something like usefulness, unless there is caries of the bone, or ulceration of the synovial membrane; it cannot be regarded as a "cure," however. This is " neurotomy," or the division of the nerres of sensation which go to the foot. It ought not to be done without evident necessity, and requires a good knowledge of the anatomy of the foot, a clear head and a steady hand. We will quoto Youatt's description of it, as it is sometimes advisable in ringbono and other difficulties of the feet:

"The horse is cast and secured, and the limb to be operated on remored from the hobbles, and extended-the hair having been previously shaved from the part. The operator then feels for the throbbing of the artery, or the round, flrm body of the nerre itself, on the side of the shank-bone, or the larger pastern. Fic vein, artery, and nerve, here run close together; the vein nearest to tho front of the leg, then the artery, and the nerve behind. He cautiously cuts through the skin, for an inch and a half in length. The ressels will then be brought into veiw, and the norvo will be distinguished from them, by its being behind, and by its whiteness. $\Lambda$ crooked needlo, with silk, is passed under it, to raiso it a little ; it is dissected from the cellular substance beneath, and about threequarters of an inch of it cut out; the first incision being mado at tho upper part, in which case the second cut will not be felt. The horse must then be turned, and the operation performed on the other side, for thero is a nervous trunk on both sides. Tho wounds are now closed with strips of adhesive-plaster, a bandage placed over them, the head tied up for two days, and the animal kept rather low, and as quiet as possible. The incisions will gen- 
erally rapidly heal, and in three weeks or a month, and sometimes earlier, the horse will be fit for work."

A healthy, unshod horse, would probably never " CUT "in travel. ling, and this at once suggests both the causes and the remedy of any such defect. If the cause is overwork, low condition, and consequent weakness, do what you can to feed him up and strengthen him at the same time that you treat him locally. If he has brought out a splint on the cannon bone in any manner, so that he strikes on that, both must be cared for. If his shoeing is bad, have that rectified. The part which he is likely to hit, however, must be padded, stockinged or booted, and this must be kept on until the soreness disappears, the swelling goes down, and the skin is healed. A bit of carpeting tied on with cloth strips and turned down over the fetlock joint, is a good pad, all the better with a piece of leather over it. Nothing but laziness will leave on any boot or pad until it has become such a mass of mud and roadgrit as to wear off the hair like a coarse sandpaper. Very little common cuteness will suffice to fit on a good "buffer" of this kind, and we leave it to your own ingenuity.

What is called "SPEEDY cUTTING" is only a worse form of ordinary cutting, requiring the application of some good healing liniment to the injured part, such as arnica liniment, and the continued wearing of a regular speedy-cut boot, in which there is a pad buckled on the inside of the leg, and reaching from the knee to the fetlock. It must be of this length in order to keep its place. Both of these difficulties occur with all imaginable gradations of severity, and must be dealt with accordingly. When they arise from malformation of the horse, or confirmed habit of travelling, there is no remedy but a perpetual use of the padded protector.

Careless smiths will sometimes drive their nails too close to the quick, and this is very apt to happen when the hoof is too much used up, even if the horse has not showed any shrinking at the time. When, on the day after shoeing, a horse which was previously sound, goes lame, and the foot is hot to the touch, it may generally be assumed that a nail or nails have been driven too near to the quick, unless there is evidence of lameness from other causes. On tapping the crust with a hammer, the horse will flinch at some particular spot, and there is the nail which is in fault. Sometimes there is little inflammation as yet set up, but the pressure of the 
nail is sufficient to cause lameness, and in either case the shoe should be taken off. Then, if there is reason to supposo that matter has formed, the opening fiom which the nail came out should bo enlarged, and the matter ailowed to escape. If, however, tho foot has been merely "bound," it may be either left to nature, with a shoe lightly tacked on, and a wet "swab" round the coronct, or it may bo placed in a bran poultice, which is the safest plan.

WUEX A XAIL IS PICKED UP ON TIE IOND, if it has entered deeply into the toe of the frog, the probability is that the navicular-joint has been wounded, or probably the tendon of the flexor at its insertion into the pedal bone, either of which are very sorious accidents. If the wound is further back, there is less risk of permanent injury, as the bulbous heels or cushion of tho frog will bear a considerable amount of injury without permanent mischief. In any caso the treatment should consist in cutting away the horn round the opening, so as to allow of a free escape of matter if it forms. At tho same time inflammation should be lept under by cold "swabs" to the coronet, cr by putting tho whole foot into a bran poultice.

Over-rescues, when slight, may be treated by the application of tincture of arnica, or other good liniments in full strength, which will havo a tendency to dry them up and prevent suppuration. If, however, the heel is very much bruised, a poultice must bo applied, but eren then a little tincture of arnica should be sprinkled on it. When the bruise is so severe that a slough or coro comes away, tho wound may be dressed with a piece of lint, dipped in a solution of nitrate of silver, eight grains to the ounce of distilled water, and orer this a bran poultice. In most cases, however, it is better to foment the part well and then apply the tincture of arnica neat.

A BRUISE on a thin sole will sometimes cause matter to form, in which case the horn must be cut away, and the case treated as for quittor. Before matter forms, the horn should be reduced, and tho foot should bo placed in a cold bran poultice. 


\section{CHAPTER TWENTY-SECOND.}

. FEVER-TYPHOIN FEVER.

Ferer-Typhoid ferer-Glanders-Farcy.

FEVER in the horse is not generally anything moro than an incident or accompaniment of other disease, such as we have already described. As an exterual symptom and warning, it may even be said to have its valuable uses. In all such cases the treament should be directed towarls the cause, or if aimed at the fever itself, only so far as that is part and parcel of the real difficulty under which the animal is suffering. In this country, however, more commonly than in Eir:ope, horses aro subject to discases similar in cause and character to those in the human system which are known as "fevers" of various kinds and types.

Simple fEVER, as we may call it, almost duplicates human symptoms. It shows itself by dulness and reluctance to move, a staring coat, and cold legs and feet, with increased warmth of the body. The pulse is quick, soft, and variable-breathing a littlo accelerated, but not much - appetite entirely lost-bowels confined, and urino scanty. These symptoms continuo for two or three days, and then either go on into the typhoid form, or they aro complicated by inflammation in some organ of the body. The treatment merely consists in giving a mild dose of physic, followed by a febrifugo drink, such as the following :-

Talse of Spirit of Nitrous Ether . . . . . $1 \mathrm{oz}$.

Nitre
Tincture of Ginger
Camphor Misture...
ad give twice a day.

Mix, and give twice a day.

Trpmord types of fever are more common in those parts of the United States where they also afflict the human race, and are likewise prone to assume an epidemic form. To this class we may assign the "black tongue" of the Southwestern States; tho 
" choking fever" of the Middle States; the "putrid fever" of tho West and Northwest; and several other lucal names of the same genoral distemper. Symptoms will vary, as a matter of course, but there are strong points of resemblance which cannot fail to serve as a guide.

The first signs present little more than debility, but, if any such disease is known to be prevalent, they should be watehed for, and promptly attended to. The next is a difficulty in swallowing. II ence the name " choking ferer." Then, with still-failing strength, the breath of the animal becomes fetid, the tongue is discolored, and there is a black discharge from the tongue and gums. Henco tho names "putrid fever," and "black tongue." Thero is very little danger that any one who has ever seen one case will fail to recognize the next, so soon as the symptoms become at all pronounced. The first thing to be done is to get the horse into a dry place, away from low ground or miasma, or the neighborhood of other animals similarly affected. If he is too weak to stand, at any time, do not let him lie too long on one side, but turn him over morning and evening. Tho diseaso is generally of a rapid and peculiarly fatal nature, but we give two prescriptions, the first from Dr. Walsch, and the second from the very able American editor of his book to which edition, by the way, we would refer our readers, for a most valuable collection of skillful information and commonsense advice, which could not be embraced in a smaller work. Wo regard erery good "horse book" as a public benefaction.

Tho treatment should be of the most generous kind, as soon as the bowels have been gently mored, which should be effected, if possible, by injection. Then give a ball two or three times a day, composed thus :

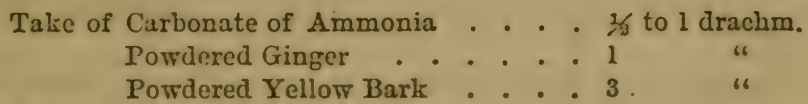

Syrup enough to make into a ball.

This should be washed down with a quart of ale caudle, and hay tea should be allowed as the drink ad libitun; or if there is diarrhoxa, rice-water may be used in the same way. Few cases, however, will recover, in spite of every exertion and careful treatmont on the part of the attendant.

Or, give the following in a drench, morning noon and night : 


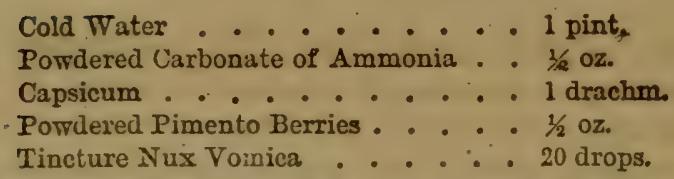

If the horse cannot swallow, drench him with cold water aud meal several times daily-adding thirty drops of commercial sulphuric acid to the drench.

If there is one horse ailment more than another to be dreaded, a sort of nightmare of horse owners, it is the GLANDERs. Nothing could be more subtly and dangerously infective, and men as well as beasts are liable to be the victims of its destructive contagion. Until. within a very few years it was but little understood and was regarded as incurable. It certainly is so, unless taken hold of in its earlier stages. When a cough, in connection with glanders, indicates diseased lungs, or when what we-describe below as the "second stage" has become confirmed, no remedies will be likely to avail, and the animal should be destroyed to prevent contagion. The disease, in the first stage, seems to be confiued to the inside lining of the nostrils; which will become of a leaden or purple color, sometimes deep, but generally very light and pale, and not of the red shade produced by chronic catarrh. There will be a thin, acrid, odorless, transparent discharge from one nostrils only, rarely from both. The horse may otherwise seem as well as ever and go on with his work, but he should be immediately put by himself, in a dry and well ventilated stable. Give him, at morning, noon and night, every day, half an ounce at a time of sulphate of soda, and five grains of Spanish fly once a day, and feed him generously to keep up his system. Keep up the treatment till every trace of the disease is removed, or until the appearance of worse symptoms declare the animal's death sentence. This may require several weeks.

In the second stage, the discharge increases in quantity, and though still watery and transparent, it is slightly sticky, indicating, the pressure of mucous. The lymphatic glands below the jaw enlarge, and become adherent to the bone, feeling hard to the touch and almost like exostosis. Here the permanent character of the discharge and the adherence of the glands to the bone distinguish it from chronic catarrh. In the third stage the discharge increases rapidly and becomes yellow and opaque-in fact, it is pure pus. 
If the nose is carefully examined, its lining membrano will be seen to present one or more sores, with depressed centres and ragged edges, and surrounded by 'small raricose ressels leading to them frum all directions. In proportion to the extent of the local mischief, constitutional disturbance is displayed. The appetite fails-the horse loses flesh and spirits-the coat is turned the wrong way - the skin is hidebound, and the legs fill slightly during the day, but go down at night-the noseis, at last, frightfully ulcerated, the sores spreading to the larynx-ulcers break out on the body - and the horse finally dies, worn to a skeleton.

No man with any regard for himself or his neighbors will keep a horse who has developed any of these later symptoms of glanders.

Farcy is supposed to be of the same cause and nature as glanders, and is equally dangerous and infectious. If taken in its earlier stages it may yield to a precisely similar treatment. If it gets beyond them, there is nothing for it but to destroy the horse at once, before more harm is done. The disease first shows itself in one or two small hard knots in the skin, called "farcy buds.' These soon soften, forming small quantities of pus. Then other buds form, usually in the thin skin of the inside of the thighs and arms, or on the neck and lips. They vary in size from a quarter to a half-dollar piece. The remaining symptoms resemble those of glanders, and the horse wastes miserably a way and dies, if his owner does not wisely and humanely anticipate the decease with a bullet. 


\section{CHAPTER TWENTY-THIRD.}

BREEDING.

Influence of sire and dam-Heat-Inheritance of qualities-Ago-SizoFoaling-Working mares-Weaning-Feeding-Handling.

I $\mathrm{T}$ is generally considered that the horse has more to do with the special characteristics of the colt than the mare, but it must not be forgotten that before birth and for some time afterward the young one gets all his nourishment from his mother, and his health and constitution cannot fail to depend very much upon the condition of her own. In fact, the preponderance of the influence of either the male or female parent upon the character of the colt will depend very much upon the relative strength of their nervous systems at the time of eoition. Hence the impossibility of laying down any general law. In the employment of any given brood-mare for the first tims, it must be borne in mind that every subsequent colt she may have is likely to bear traces of that first impregnation. Do not start her with an inferior horse. Not only natural but acquired qualities are transmitted, whether they belong to the siro or dam, and also both bodily and mental. As bad qualities are quite as easily transmitted as good ones, if not more so, it is necessary to take care that in selecting a male he is free from bad points as well as furnished with good ones. It is known by experience that the good or bad points of the progenitors of the sire or dam are almost as likely to appear again in the offspring as those of the immediate parents in whom they are dormant. Hence, in breeding, he rulo is, that like prodnces like, or the likeness of some ancestor.

The period of "heat" is marked by certain discharges and other symptoms in the mare, and the horse will show it plainly enough, and the latter part of the time of heat is considered the best and surest.

In this country our mares are generally of a more "mixed" descent than our breeding stallions, and as pure blooded animals 
transmit more of their own nature to their offspring, this adds very materially to the greater importance of the selection of the male. We do not generally find ourselves in danger of too much "in-andin "breeding, and need not discuss that point, except to say that "once in and once out" has been accepted as a gnod rule among very successful breeders.

You cannot expect a slow, stout mare, with no fast ancestry, to bring you a rapid traveller from ever so fast a stallion, but that colt, if a mare, will do a great deal better when her turn comes, and so on. When single instances of apparent good luck seem to contradict this rule, an explanation will generally bo found by going back two or three generations, if that is at all possible.

Do not expect to make an arithmetical example of a horse and mare, and produce a colt representing both of them in any exact proportion. The young animal will be heir not only to his own father and mother, but to theirs before them, and the sum total of his " birthright" is quite likely to be a puzzle of reproduction.

There can be no doubt, however, of the importance of noting tho health; habits, vices and other peculiarities, of both sire and dam, and of avoiding anything in either which you would consider undesirable in the colt.

Do not let both horse and mare be either very young or very old. If one is young, let the other be older, and vice versa. Many of tho best horses on record havo been begotten by vigorous old stallions of seventeen to twenty-two years, and the same is true of sound old mares, and age is no bar to success, but such instances are raro where both parents were old or feeble. The general rule adopted by English breeders is that the dam should not be less than threo years old, and the sire at least seven. Wo should much prefer the mare to be at least fire.

The size of a colt will be governed less by the accidental bulk of either of his parents than by that of their "lino" or breed, and this occasions not a few disappointments, both pleasant and unpleasant.

Mares of moderate size are generally stronger and mako better breeders than large ones, unless the latter come from an exceptionally largo breed.

Bearing these hints in mind, and using a fair degree of judgment, almost anybody ean manage to secure colts that it will bo worth while to raise. 
Keep the mare up near the stable at foaling time, and she will be pretty sure to give a few hours notice of what is coming. After foaling keep mother and colt enclosed by themselves, if possible, until the latter is able to take care of itself, somewhat. We lost a very nice colt, a while ago, by neglecting this. Do not forget that colts are full of mischief and nonsense, and will be very apt to hurt themselves if they have a chance.

As to working brood-mares, all mares are the better for moderate work up to within two months of foaling, but care should be taken not to urge them or over-drive them.

Mares should be so timed that the foals may be dropped about the time grass becomes good for the mother, aud out-door weather fairly steady, and this varies too much in our broad territory to give a rule.

WHEN the MARE IS IN FOAL, if not intended to be kept at work, she should be turned out in goud pasture; but it should not be so rich and succulent as to disagree with her stomach, or mako her unwieldy from fat. The former mistake is a constant cause of miscarriage, the bowels becoming relaxed from the improper nature of the food. On the other hand, if it is not sufficiently good, the mare will becoms thin, and will starve her foal in its growth. Mares that have been corned highly all their lives should have a feed or two daily, after they are six months gone, and especially if the autumnal grasses are not rich and plentiful. Most animals, however, do very well till about Christmas; after which, hay and corn, with a few carrots, should be liberally given them, still allowing them to pick up what grass they can find. Excessivo fat interferes with the due nutrition of the fatus, while it is very dangerous at foaling-time, when it not only interferes with the process, but also tends to produce fever. Supposing the mare to be at work, she should have some kind of green food. Any of tho grasses or clovers answer well; and, after they are done carrots are excellent, given sliced in a bran-mash every night. By adopting these articles of food, the mare is kept free fiom inflammation, and yet the foal is well nourished, which are tho two essential points to be considercd.

EXCITEMExt of every kind is a fertile source of "slipping " the foal; and everything which is at all likely to have that effect should be carefully avoided. The smell of blood is said to have a 
very prejudicial influence in this way. If a mare has "slipped" a foal in a previous pregnancy, double care should be taken, as sho will be far more likely to do so again than another which has hitherto escaped the acciclent. It occurs most frequently about the fourth or fifth month, therefore extra care should be taken at that time. Purging physic should not be giren, unless it is absolutely neces6ary; and if the bowels are so confined as to require some stimulus of this kind, and bran-mashes and other changes in tho food fail to produce any effect, choice should be made of the mildest aperient which is likely to answer the purpose.

At the time of foaling, the mare will to a great extent talie care of herself, but if you can have experienced assistance at hand it is well to do so.

A good healthy mare is rery litule cxhausted by the birth of a foal, and if the weather is good, she may be let out in a couple of clays. Care should be taken as to what other animals are permitted in the same enclosuie, aroiding vicious or ugly-tempered brutes. Until the grass is plentiful see that the mare has plenty of good fool. Carrots, bran-mashes, oat-gruel, cut clover, nothing nice and succulent is likely to come amiss, and both mare and colt will show the good effects. If otherwise in good health, neither mare nor colt require other attention than gool shelter from bal weather and regular feeding, during the rest of suckling time. At weaning time, the mare is generally nearly dry, and nceds no help. If otherwise, a close of some cooling medicine may be bencficial.

The future value of a horse depends a good deal upon his treatment when a colt. Ile will get along splendidly by himself for his first summer, accidents and diseases exeepterl, but will be all the better, after his second month, for a mall fecl of bruised oats daily. Shelter from storns he must have, and particularly when the chilling weather of later autumn comes on. In winter he must have a place to get warn in and something dry to stand on, if he is to derelop a sound constitution. Crueliy and neglect aro miserable waste, and a man who is careless of his colt is throwing away his horse. The care, howcrer, must not be umatural, or such as will make the animal tender and helpless. Make him take the cold, dry air, and trust his young blood that he will take all the exercise he can get.

If we were askod at what age "training and breaking " ehould 
begin, we should reply, "By no means before the colt is bo:n." $A$ s soon as possible afterwards, he should be made familiar with gentle handling, and gently taught to obej. Rough language, rough handling, teazing, anything that will startle or scare him, any show of bad temper at his caprices, will surely give his education a wrong turn. This is the time when the horse berins to collect his habits, bad and good, as well as to show what he has inherited. If the latter is bad it can be mostly got rid of now. The process of handing must be gradual, and without any unnecessary "foolery." Bofore weaning, and about the fourth or fifth monilh, it will bo well to put on a light headstall, and after that a leading rein, and the little follow can be taught to follow and obey in such a way that he will never dream of resistance. It will be naiure to him. After the sixth month, in which a colt is usually weaned, the process of feeding will give good chances for carrying on his education, and, if his feed and care are what they ought to be, his growth need have no check, and his tomper may almost invariably be kept good. 


\section{CHAPTER TWTNTY-FOURTH.}

\section{TRAINING FOR WORK.}

THE idea of breaking a colt to work seems to be naturally associated in the minds of most, and especially the inexperienced, with overcoming some terribie natural obstacle by a combination of human force and fraud, and the product of many generations of domestic use and education, familiar from his birth with human companionship and the ways of men, is practically put upon the same level with the wild horse of the savannas, or even the vicious carnivora of the menagerie. The common-sense and sound teaching of these latter days has done much to dissipate such erroneous and hurtful notions, but they are still permitted to accomplish a vast amount of needless mischief.

Even the humane doctrines of MIr. Rarey, and other trainers, are lost sight of by stupidity in a sort of open-mouthed wonder at his conquests over exceptional cases of acquired or inherited vice, and too many are apparently inclined to imagine that the gentlo and tractable pets of their own farmyards, the playmates, it may be, of their own children, are under some inscrutable necessity of boing "Rareyfied" before they will take kindly to the weight of the saddle, or the drag of the harness. The writer of this book has no fear of being contradicted by any respectable trainer in laying it down as a fundamental principle that, other things being equal, that horse will be the best "broken," freest from trick and vice, most reliable and obedient, and, at the same time, the most spirited and enduring, whose course of education has been such that he cannot recall any time when he was not broken. He should have no memory of any hour of great trouble and fear when he first discovered that man was his master, and that all his strugogles for freedom were in vain. Here we can do no better than to quoto what Mr. Rarey lays down as the net result of his own remarkably wide and varied experience. Ho says :

"First, That the horse is so constituted by nature that he will 
not offer resistance to any demand made of him which he fully comprehends, if made in a way consistent with the laws of his nature.

"Secondly, That he has no consciousness of his strength be. yond his experience, and can be handled according to our will without force.

"Thirdly, That we can, in compliance with the laws of his nature, by which he eximines all things new to him, take any object, however frightful, around, over, or on him, that does not inflict pain, without causing him to fear."

It will at once be gathered from this that as God intended the horse for the friend, companion and servant of man, he made no blunder in so constituting the animal that men of average sense should be able to turn him to account without great trouble or any cruelty whatever. Of Mr. Rarey's special method in dealing with brutes that have been spoiled in the training, or whose early education has been neglected, we haro no room to speak, and must content ourselves with a few hints concerning the class of colts of which we have been mpre particularly speaking.

If the owner of the colt has begun with him as we suggested in the last chapter, he will alreacly be accustomed to wear something on his head and neck, and the form and style of this can be so changed, from time to time, that he will find nothing "strange," or alarming, in any sort of headgear. Nor is this attended with any especial expense of time or trouble. Eren if haitering has been neglected until the animal is two or three years old, the process of getting him used to it should have as little of suddenness about it as may be.

The next stumbling block is the bit, and this should be of a sim. ple form, with side pieces to keep it from slipping in the mouth. The more gratnally the colt is taught to bear pressure on his mouth, the less likely he will be to become "hard bitted," and disposed ta make the reins and his driver's arms do the work of the traces and singletree. The forms and styles of "breaking. bits " are numerous now-a-days, and none of them are rery bad if they are used rightly. Do not attempt to teach the colt what the bit is put in his mouth for until he has become somewhat indiffer. ent to having it there. He will readily consent to receive ideas and orders through it, as if it was, in a way, a pait of himself. 
Do not forget that a badly educated mouth means a badly trained horse. The whole business of management hinges upon this beginning. If the colt, for any reason, takes unkinaly to his bit. ting, keep, him in the stable, and keep his head down somewhat with a martingale.

Do not carry this too far, lowever, for at all stages of his training the horse must be accustomed to exercise with his gear on, whatever it is. The more he can be taught to bear pressure on his. bit by a gentle human hand on the reins, the better, and if a surcingle: is employed, the reins shoukd be drawn littlo by littic, so that the animal can at any time relieve the pressure en his mouth by lowering his head. The more quiet handling and kind words yout can give him, the better, varying the time taken for each successivo lesson according to the temper shown, and the tractability of tho animal, for no two horses are exactly alike in their requirements.

The next point of education is the surcingle, of which the colt. should be allowed a good smell, and which should be rubbed orer him until he is no longer afraid of it. The buckling on and tightening should not be hurried, especially with thin-skinned and nervous fellows. Even with such we havo passed readily from surcingle to blanket, and from that to pad and saddle, without a single vicious plunge, or anything like a "scare."

If the horse is to be sadule-broken first, which is generally easiest and best, he should be tanght the meaning of the reins, and become accustomed to the pressure of the saddle, and some light. weight on it, as well as to the jingle and motion of the stirrups, before he is mounted. The first mounting is necessarily quite an event in the life of a horse, howerer carefully be may have been prepared foi it, though some will tale it quite as a matter of course, aid make alinost no fuss at all. Another writer, who. evidently agrees with us, says :

"The breaker should during the last week's exercise, before mounting; put on a saddle instead of a roller and surcingre, keeping it in its place by loose girths and a crupper. Every day lie should bear occasionally upon the stirrups, smacking them against. the saddle, and thus accustoming the colt to noises, and also topressure on his bacis. When all is rearly, he has cnly to put his foot in the stirrup, standing with his back to the shoulder, and then, after partially rising two or three times, and coming downs 
again, he finally plants himself firmly in the saddle. Most careful breakers have a roll of cloth buckled firmly in front of their saddles ; and with this precaution, even if the colt bucks or kicks, it is almost impossible for him to dislodge them. When thus mounted the breaker should be in no hurry, but let the colt get accnstomed to the intruler. Let him wait till the pupil has somewhat recovered from the shock, and then only let him urge him forwail at as slow a pace as he likes. If all has been conducted well throughout the preliminary stages, and the colt is good-tempered, he will walk away quictly enough, and generally no trouble will be given for a day or two ; when. probably, there will be somo slight fight, which may be either in causing the pupil to go where he does not want to go, or in making him face some object which frightens him. At first, neither whip nor spur should be used, for the object of neither is understood; and if the colt will not readily move forward, he should be led or driven by an assistant, and not whipped or spurred by his rider. In jrocess of time, however, he is made gradually to understand these signs by the tact of the breaker; and then if he offends, he must be punished accordingly, but it must always be remembered that the fault must be met immediately, or not at all."

We have long held the opinion that liorses generally laid the foundation, so to speals, of their worst faults and tricks, in their very first experiences, at any kind of work, and probably often in incidents or accidents that were unnoticeable at the time.

It is partly for this reason that we urge so strongly that the "brealing" process should be attended with the very least possible degree of pain or fear. At no other time is courage, patience and thorough good temper of such importance on the part of the trainer. For this reason also, we would not allow a timid, quicktempered, cruel or ignorant person, to have any thing to do with a colt, at any time, as such a person would be so very likely to do or omit something, in a way to permanently diminish his value or usefulness If an unbroken colt comes into the hands of any of -our readers, and they desire to experiment on him, we would advise, before going on with our instructions, that the first step should be to so to make the stranger's acquaintance that he will feel entirely "at home and among friends" before anything more is attempted with him. If this cannot be dcne, for any reason, why, then the ordinary methods must take their course, hit or miss, with a fair chance for making some kind of a "miss."

If a colt has progressed so far that he will go kindly under the saddle, and has learned to have some confidence in his rider, or if it is not intended to saddle-break him, and he has veen pretty thoroughly bitted and taught the meaning of the reins, the next step will probaluly be to break him to harneos. This ought to bo a very easy and simple process, if the colt is so taught not to fear 
his harness that his first lesson is reduced to the mere fact of pulling. If the colt is at all shy or nervous, it would be well to put on and take off the harness for several days in succession, before going any farther. He should be made especially familiar with his collar, both by sight and smell, and it should from the first bo put on orer his head in the ordinary way, so that he shall know just what it is that is pressing on his shoulders when he begins to pull. That knowledge may savo him a deleterious fright and consequent backing and plunging.

It may be that circumstances will compel you to break the colt by himself, in single harness, and this may have its advantages, enabling you to humor him and let him take his own time in getting used to his new circumstances. The better way, probably, is to take advantage of the fict that the horse is a very imitative fellow, and very apt to be reassured by the company of one of his own kind, and put him in for the first time in double harness with some steady-going and reliable old roadster, who will start and stop at the will of the driver, and force his young companion to do the same. For our own part, we would drive a green horse double for a good while, if possible, before allowing him to be put in by himself. Even then it may be found that he hardly understands himself or knows what to do. It is a curious fact that an old horse who has been used several times as a "break horse," will take quite an interest in the education of his young companion and be of more than a little service. Do not employ in such a capacity a beast that has shown any signs of vice, unless you desire to get into the worst kind of a scrape with both of them.

Be sure that you have not provided too heavy a pull for your pupil, to hurt his shoulders at first, and give him such a disgust with his collar that he will be inclined to back or baulk the next time he feels its pressure. Put in the old horse first, and havo things headed right and all clear for a sudden start, if one should come. Then lead up the colt quietly, with all his harness on. Crowd him gontly into his place. Buckle up as near like lightning as you can without making the least degree of fuss or worry. Then the driver may spring to his seat, take the reins, and say nothing. No shouting, no whipping, only a quiet chirp to the old horse, and no notice to the young one, and the chances are three to one that the pair will step right off without a sign of resistance from the colt. If he should rebel, the conduct of the driver may depend somewhat on that of the colt, with this proviso, that steady patience and plenty of time are worth all the lashing in the world.

Do not drive very fast, no matter how well you get off, and travel straight on without stopping until you are sure that your pupil begins to feel some degree of ease at his work. This will of course require a longer time if there has been anything of a struggle or bad temper at the outset. You may drive three or 
four miles, perhaps, and then, if all is going well, try a few lessons in stopping or starting, or in turning. Do not do this, howerer, if you have had any trouble, but leare it until next day, contenting yourself with what you have taught at the collar. And now do not overdo this, but hasten home beiore the colt's shoulder is over tired or rendered likely to be stiff next day, for if it is he will be sure to flinch and back, and your second lesson will be harder than your first. This is one of the ways in which bad backers are made. By degrees the colt will learn all that you can teach him in double harness, and become as stearly and reliab!e as his veteran companion.

As a general thing there is more to be feared from a colt's first attempt to pull alone than from the experiments which we have described, as in the latter case the companion horse counts for a great deal, and the sense of independence seems to have a natural tendency to "bring out the bad," whether of temper or timidity. Therefore it is well to use some care on the first trial, and to provide for emergencies. Use a strongr larness and a "break-wagon," if you can get one, the latter hi-h enough to make it almost impossible for the horse to lick over the bar. Always put on a kicking strap and safety rein, for fear of accilents, and have the tugs open above so as to clrop the shafts into them. If all things have been woll managed hitherto there will probably be no trouble, and if there is it will be in starting, in the absence of the other horse. In the absence of any cause of fright, strong arms and a steady hand will pretty surely prerent a runaway-and it must be prevented-bul for refusing to start it is best to wait patiently. It is not time yet to use the whip, except in rare cases. Backing is not often tried, but if it is every exertion should be used to mule the attempt absolutely unsuccessful. If we were asked what was the one most important piece of harness in teaching a horse to work, we should unhesitating!y answer, " tho patience and couragro of his driver."

It is of more importance with young horses than even with old that tb. barness should sit easily upon him, so as not to chafe or gall, a o that no worls should be required beyond the animal's reasonfile stiength.

The nest care should be against fright, or the acquisition of real or pretendel tricks of fear concerning particular objects. A little care at the beginning will secure comfort and safety in uso and higher price on the day of sale. 


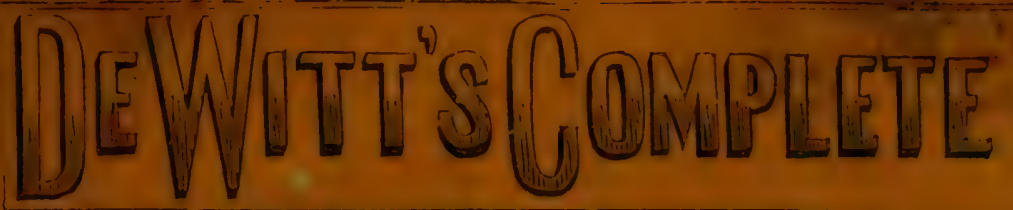

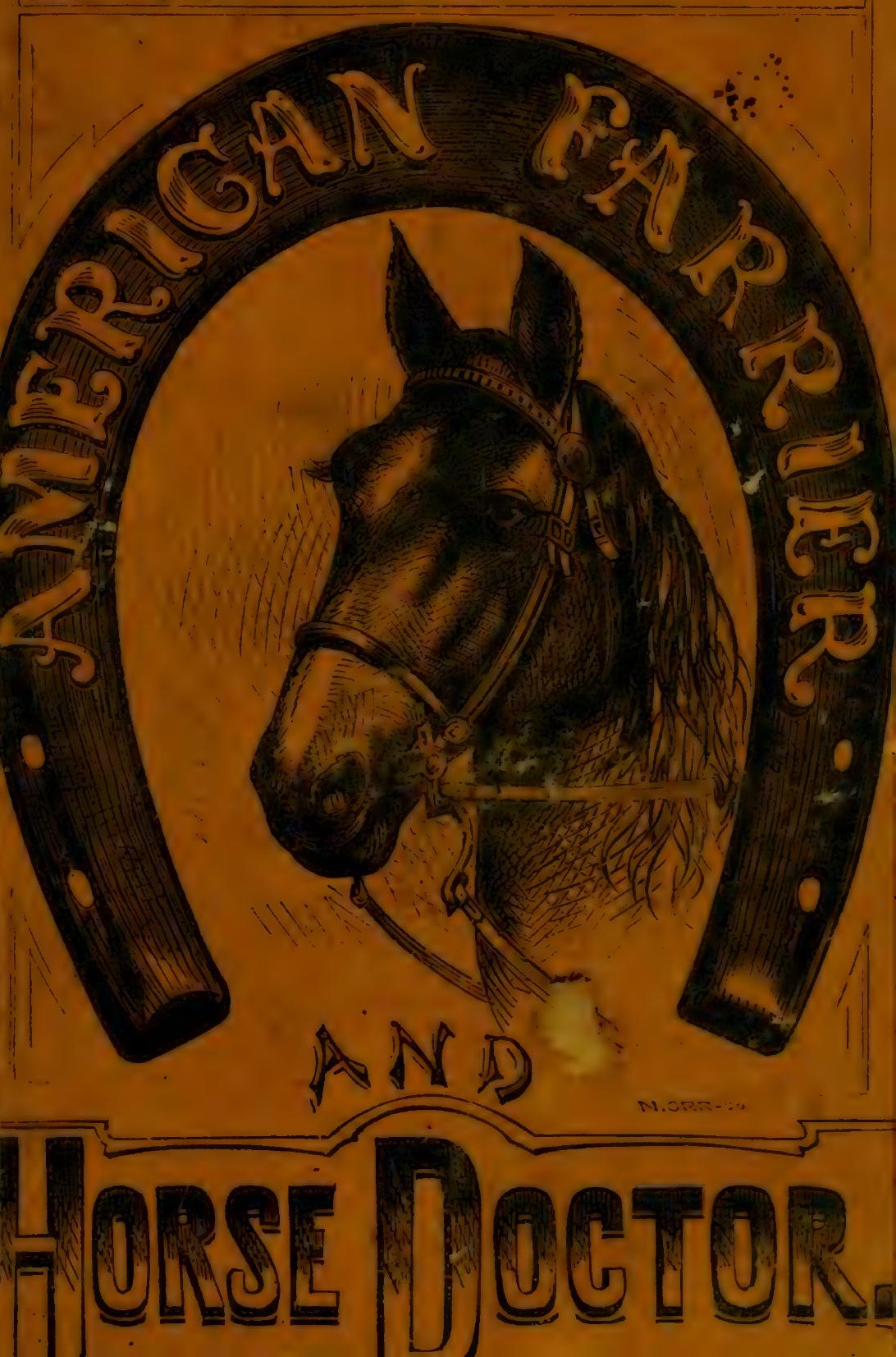




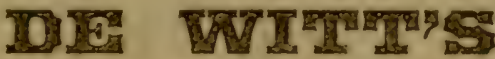

\section{Cheap Edition of the Works of}

\section{CAPTAIN}

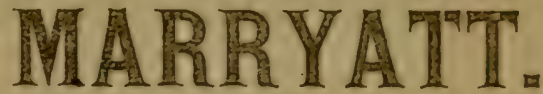

In purely nautical description, Marryatt equals our own Cooper, and in humorous details of the "jolly" tar, surpasses even his countryman Smollett. They are the "classics" of the sea; and great is the treat which all miss who have not wept and laughed over his pages. The edition is from the latest revised copy, and is the cheapest in the world.

Jacob Faitheru.-There has rarely been a man placed in a position so fitted for seeing the sallor's life, as Captain Marryatt, and there has never been an observer so able in portraying what he has witnessed. Price.................25 cts.

Snnrleyote the Pog Fiend. -If laughing makes neople increase in bulk, "Snarleyow" would hive been found guilty of making Daniel Lamberts of the human race, tor never was there a book so many readers have roared over and none so worthy of exciting laughter. Price....................25 ets.

Midshipran E Easy - This writer never wote a slull book, anct this one is least of atl open to that fitult. Price...............25 cts.

'The pirate and the "linee Carters.-At the word "Pirate," all kinds of visions arise betore the speaker's eves - frowning men clambering aboard contested craft, shots exchanged, cutlasses clishing, in short a fierce encounter with the crew of the ship assailed by the ocean rover: or, nerhans a scene of the quiet nook where slepps the pirate cutter, and where its crew caronse. Price..............25 ets.

Newton E'oster.-One perusal of this book will crive a clearer iclea of a seaman's existence than a vorage round the Horn. Neither terrible nor merry adventures are omitted. Price....................25 cts.
Japhet in Search of a Father.-Some years liave elapsed since this eminent nuval novelist penned his list work, but there has risen not one worthy to wield his unrivalled pen, nor equal even the wonderiul powers of language displayed in "Japhet." Price...........25 cts.

Peter Simple.-If the same authos had not written other novels, this would be the best sea story in the language; as it is, it is one of the best. Price .............25 cts.

'E'he King's Ovm.-Some physicians prescribe for certain patients sea vosages. If we werc the latter, and dreading to obey the doctor's order on account of the disagreeable things on shipboard, we would order Marryatt's Works, and read them all, beginning with "The King's Own." "Thus we would have unalloyed enjoyment: the seabreeze, the exciting episcdes, the novel, interesting sights, scenes and and persons, without the discom. forts attending them. Price $25 \mathrm{cts}$.

Pacha of II any 'Gales.-The Miny 'Tales will be fornd equal to one another, and all excellent, and never tedious in length......25 cts.

Frank prildmay.-Ferr can excite their readers, at a simple wave of their pen, to either enthusiasm or laushter, but MIarryatt possesses this gitt. and, perhaps, in no other work does he better evinc: it i han in "Frauk MIildmay." Price $23 \mathrm{cts}$.

DED Copies of any of the above lioolis will be schl, free of postage, on receint of the retail price.

Send Cash Orlers to R. M. DE WITT, No. 33 Rose St., N. Y. 


\section{WEBSTER'S RECITER; \\ OR,}

\section{WLOCUTION MADE EASY.}

Plainly showing

\section{THE PROPER ATTITUDES OF THE FIGURE,}

THE VARIOUS EXPRESSION'S OF THE FACE,

And the Different Inflexions and Modulation of the Voice,

Clearty Explained by

\section{NUTFEROUS ENGHEA VINGS.}

Arso Coxtainixg

Choico Selections of the MIost 'Thrilling, Passionate, Heroic und Patriotic Speeches and Roems, with

Appropriate Instructions to enable tbe

Hearner to fit himself for either the

Stage, the Hiar, the Formm,

or the Pulpit.

BY THE AUTHOR OF

\section{'WEBSTER'S PRACTICAL LETTER WRITER."}

\section{ILLUSTRATIONS.}

FIGURE I.-GRIEF.

FIGURE II.-DisLIKE.

FIGURE III.-MUDESTY.

FIGURE IV. - REGIET.

FIGURE V.-REsulotion.

FIGURE VI.-ADariRation.

FIGURE VII.-CAUTION.

FIGURE VIII.-ADORATION.
FIGURE IX.-DISDATצ. FIGURE X.-CURSING. FIGURE XT.-APPEAL. FIGUURE XII.-HATE. FIGURE XIII.-PATRIOTISM. FIGURE XIV.-CoUHage. FIGURE XV.-INYOCATION.

These Illustrations are very superior, excelling in accuracy of delineation, and beauty of execution, anything erer yet produced for a like purpose.

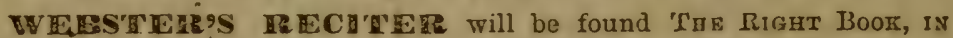
Im: RIGHT PLACr, if it is lound in the hands of every person desirous of making himself a perfect master of the useful and noble art of ORATORY.

This book contains over 200 pages, bound in boards, with a splendid illuminated cover. Friee - 口 - 口 - - 50 Cents.

A handsome and durable edition of this work, bound in cloth, elegantly lettered in gilt. Price $-\infty-\infty \quad-\infty$ Cents.

res Copies of the above Buols sent to any address in the Unted States or c'anadas, free of charge.

Send Cash Orders to R. M. DE WITT, 
THE CHEAPEST COLLECTION OF MUSIC EVER PUBLISHED. PRICE 50 Cents.

Al Regular Mlusio Publishers' Prices, this Number of Pieces would cost over FIFE DOLLARS.

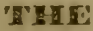

CAPTAIN JINKS MUSICAL ALBUM,

CONTAINING FIFTEEN PIECES OF

THE MOST POPULAR MUSIC,

Arranged for the Voice and the Piano.

I3Y HIEN RY 'TUCKER.

Captain Jinks.

Chanpagne Cinarie.

'l'assels on the Boots.

'Tommy Bodal.

है $p$ ink a Haklloon.

Not for Toseph.

tmmenseikor.

Bell fioes A-IRinging for Sai-ralu.

** Printed on heary MIusic paper, with an elegant litliographic cover printed in colors.

Price Fifty Cents.

THE CHEAPEST COLLECTION OF MOSIC IVER PUBLISHED. PRICE 50 Cents.

At Regular Music Publishers Prices, this Number of Pieces vould cost vier FIVE DOLLARS.

\section{Bryant's Casket of Musical Gems,}

Containing FIFTEEN PIECES of the very finest Songs and Ballads as Sung by THE BRYANT OPERA TROUPE.

Arranged for the Voice and the Piano.

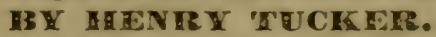

Uittle Magric May.

'Thy Vuice is Near.

hover's Letter-BBox.

Fisherman's Danghter.

Chickabiday; or, Goodbye, dohu.

Far Away.

twinere is itgy Namey.

Cail Ifer IJack and In iss Ixer.

** Printed on heary MLusic paper, with an elegaut l.thorraphic cover printed in colors.

Price rifty Cents.

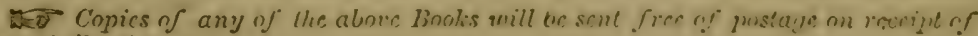
the relail price.

Send Cash Orders to R. M. DE WITT, Yo. 33 Rnse St., X. I. 


\section{THE \\ Blonde of the Period Songster.}

CONTAINING NEARLY 200 POPULAR SONGS,

Of which over Twenty are Set to IIusic Expressly for this Work. AS FOILOES:

Trassels on the rboots.

Hulling Irard Against the strean.

FBearitiful IBells.

Fishexman's Datughter.

Shabby Getnteel.

Bretty ritue Prary.

IVIabel Evaltz.

EVill Jones and Susan .0 ande.

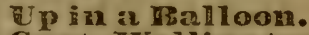

Carzt. Vellington de mots. 'E U atcin the City's Peace. "Tonany Eoda.

O, Vyoulden't Wou hike to 㑔 $\mathrm{n}$ ○

Fancastire Inss.

Shells of Bcean.

"Whe Velocipede.

"True lislue and 72 .

Pretty Rolly, if Nou Love IVIc, do $5 a y$ Yes.

I'11'ell Your Vife.

rine Meiden and Her Lix. net.

This book is one sparkling carcanet of song and ballad brilliants. Nothing more complete in the song Book line has ever been produced. Hardly a single good song can be thought of that the "BLONDE OF TuE Period SoNgsti:n:" don't enclose in its beautifully colored covers. It is as handsome in appearance as it is intrinsically good. Humorous, sentimental, farcical, pathetic, attratc, page after page, giving great diversity as well as large quantity to its contents, it is bound tu be a standard Songster wherever it reaches, and it will sell for years, every where.

Enclosed in a lithographic cover, printed in colors, 200 pages, and retails for

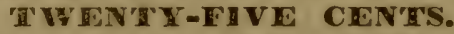

\section{DAN BRYANT'S \\ "Shaun the Post" Songster.}

CONTAINING NEARLY 200 IRISH SONGS.

To which are added Twenty Capital Songs, Set to Music Expressly for this Work.

Par Excellence; the Idol / Knew that I Was Dreamof the Day.

The giaby Sliow.

Cackle, Cackle, Cackle!

Hon 1 Ter Par.

Navglnty IVary. Ana.

Rot so RBad for IRe.

Trkere's Notlning Like Pride

About Tle.

TiJy Jolniny Love was a

Soldier.

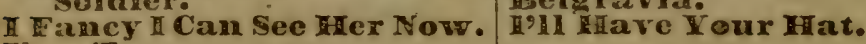

Up a tree.

Almost every good Irish Song ever sung, will be found in these handsome pages-besides as much new and sparkling music as would cost three or four dollars at Music Publishers' prices.

$\Lambda$ splendid colored cover encloses this capital Song Book of 200 pages.

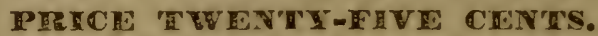

0.5 Copics of any of the above Conlis will be sent free of postage, on receint of the relail price.

Send Cash 0:ders to R. M. DE WITT, No. 23 Rose St., N. Y. 


\section{DE WITT'S

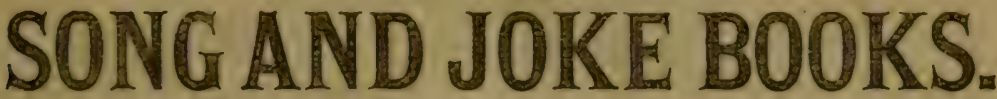

These Song Books contain all the new songs of the day, adanted to wellknown and popular tunes. The Joke books contain the most laughable and amusing jokes ever published. - Each book contains sixty-four pages, printed on fine white paper, and enclosed in a handsome cover with an Illustrative Lngraving, and sold at the remarliably low price of Ten Cents each.

1. 'Ceddy Regan Songrster. - Being a collection of new and chuice I rish songs-sentimental, comie, rollicking-full of wit and humor.

2. Hat DTsiloy Songster.New and rare Irish songs, full of wit and humor, making it the cheapest Irish songster published.

3. Shanus 9'Irien Songster.-Irish all over: like regular potcen whiskey, "wid de smell uv de smoke on it."

4. TVearing of the freen Songster.-Containing a selection of patriotic and comic songs, duetts, trios and sentimental ballads.

5. 'Tim Finnigan's TFalre Songster. The author must have raked the "ould soll" to have gathered up such galore old and new Irish songs.

6. Hendy Amdy Song Moolk.-Being a collection of new and choice Irish songs-sentimental, comic, rollicking-exceedingly rich.

7. Paddy's Den Dime Song Bsoolk.-Contrining a choice selection of comic songs, dietts, trios and seutimental ballacls.

8. Jolly Trignman's Song ster.-A new and bang-up Irish songster. The song of the Jolly Irishman is creating an immense furore all over the country.

9. FE ocky read to Dublin Songster.-The cream of jolly, light-hearted, mirthful melodies fit these roaring songs.

10. Noraln OYeal Songster. Irish songs of the "rale ould sort" are sand wiched betwayn many of the most deservaly popular nnes.
11. Annie Lanrie Melodist. - Containing eighty-four jonular songs and ballads; arranged and set to music by one of our most popular musicians.

12. Ireet The in the line Songster. - No finer collection of very interesting, and beautiful. and sentimental songs and ballads has ever appeaxed.

13. Gipsy's Warming Songster.-The sweet and plaintive song of the "Gipsy's Warning" is more than worth the price of the buok.

14. Sy inging in the Lane Songster.-One would sit all Cay "swinging in the lane," with no other companion that this most enjoyable collection.

15. Pretty Little Sarah Songster.-Nothing in the song line seems to have escaped the compiler of this charming songster.

16. Paddle Your Own Canoe Songster. - Nerer was there a better lot of songs got tagether. "Fresh, sparkling, funny and sentimental.

17. Goose Hangs High Songster. A collection of sharp and spicy songs, with a dash of "don't care" about them that will do fur the boys.

18. Viva la Compagnic Songster.-This contains a new and original song, written to the well-lsnown drinking melody of "Viva la Compagnie."

19. Nareglet, Naughty

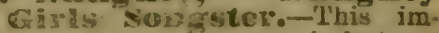
mensely popular eong is but one of the dom a cqually good th: have : place Lere.

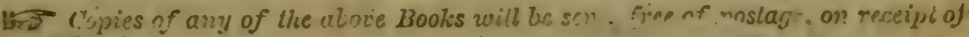
vie retail sirice.

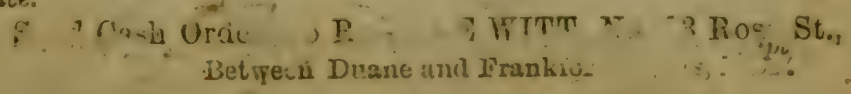




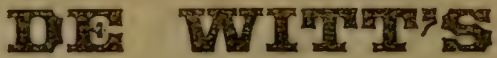

\section{ACTING

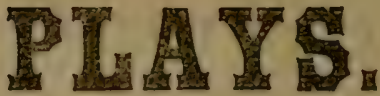

PRICE FIFTEEN CENTS.

The following list of Pliys comprises nearly all the great successes of the leading Dramatic Authors of the day. 'There is not a single piece among them that has not been played over and over again, to immense houses, in the leading Theatres of Great Britain, and in some of the principal American houses. Each piece has ample and perfect directions for eflectively putting it upon the stage, and every possible assistance is given to the stage-manager and prompter. The edition is handsomely printed from clear, legible type, upon white paper.

1. Caste. An original Comedy, in three Acts. By I. W. Robertson, Esq. Five Arale, three Female Characters. Price.........15 cts.

2. Nobody's Child.-A Dramatic Play, in three Acts. Hy Watts Phillips, Esq. Eighteen Male, two Female Characters.

Price..................... 15 cts.

3. $\mathbb{E} 100,000 .-\mathrm{By}$ H. J. Byron, Esq., one of the most popular English Dramatists. Eight Male, tour-Female Characters.

Prico....................15 cts.

4. Dardelion's Dodges. - A Farce, in one Act. By T. J. Williams. Four Mrie, two Female Characters. Price.........15 cts.

5. William "gell, with a Vengenuce: $A$ Burlesque, in two Acts. By H. J. Byron, Esq. Fight Male, two Female Characters. Price.........15 cts.

6. Six Ironths A $\mathrm{so}-\mathrm{A}$ Faree, in one Act. Bg Felix Dale, Esq: Two Mrale, one Female Characters. Price................15 cts.

7. gratd's Peril.-A Drama, in four Acts. By Watts Phillips, Esq. Five Male, three Female Characters. Price..........15 cts.

8. Henry Dunbar.-A Drama, in four Acts. By Tom Taylor, Esq. Ten Male, three Female Characters. Price................15 cts.
9. A Fearful Tragedy in the Seren Dial-A Farcical Intexlude, in s Act. By Charles Selby, Cor edian. Four Male, one Femaie Characters. Prien....................15 cts.

10. Fhe Snapping 'Turtles; or, Inatrimomial IVas quexading..-A Duologue, in one Act. ByJohn B. Buckstone. One Arale, one Female Characters. Price.................15 cts.

\section{Wookcock's rittle} Ganme-A Comedy Farce, in two Acts. By John Maddison M.orton. Four Male, two Female Characters. Price........15 cts.

12. A Hidow Iunt.-Ä Comedy, in three Acts. (Altered from his own comedy of "Everybody's Friend.") By J. Sterling Coyne. Four Male, four Female Characters. Price...............15 cts.

13. Ievy. Blas.-A Romantic Drama, in four Acts. From the French of Victor Hugo. Twelve Male, four Female Characters. Price.....................15 cts.

14. No Thorouglifare. $-\mathrm{A}$ Drama, in five Acts and a Prologue. By Charles Dickens and Wilkie Collins. 'Thirteen Male, six Female Characters.

Price.....................15 cts.

10- Copies of any of the above Bools will be sent frec, of postage, on receipt of the retail price.

Send Cash Orders to R. M. DE WITT, No. 33 Rose St., N. Y. 


\section{DH WITI'S}

\section{ACINC}
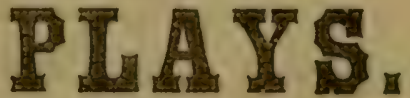

(CONTINUED.)

15. Milky VWhite.- $\Lambda \mathrm{n}$ Original Dowestic Drama, in two Acts. By H. T. Craven. Four Male, two Female Characters.

Price..................15 cts.

16. Dearer than tife.-A Serio-Comic Drama, in two Acts. By Henry J. Byron. Six Male, five Female Characters.

Price....................15 cts.

17. Lrind to a Fault.-A Comedy in two Acts By ivilliam Brough. Six Male, four Fcmale Characters. 1'rice....15 cts.

18. If I Fad a rhousand a Vear.-A Farce, in one Act. By John Maddison Morton. Four Aiale, three Female Characters. Price....................15 cts.

19. He's a Lunatic.-A Farce, in one Act. By Felix Dale, Esq. Three Male, two Female Characters. Price..............15 cts.

20. Daddy Gray.-A Serio. Comio Urama, in three Acts. By Andrew Halliday. Eight IIale, four Female Characters.

Price...................15 cts.

21. Flay.-A Comedy, in four Acts. By 'I'. W. Robertson. Seven IIale, three Female Characters. Price.............15 cts.

22. David Garrick. $-\Lambda$ Comedy, in three Acts. By T. IV. Robertson. Eight Male, three Female Characters. Price $15 \mathrm{cts}$.

23. Whe Petticont Parliawent. - An Extravaganza, in one $\Lambda$ ct. By Mark Lemon. Fifteen Male, twenty-four Female Characters, Price.........15 cts.

24. Cabiman No. 93 : Or', Forme in a Four er. $-A$ Farce, in one Act. $B$ V ' J. Williams, Lsq. 'Two Alale, two Female Characters. I'rice $15 \mathrm{cts}$.

25. "The" Barolierolyearied Club.-A Comedictti. $13 y^{\circ} \mathrm{J}$. Sterling Coyne. Inur Male, eight Female Characters. Price 15 cts.
26. Seciesy. A Comedy, in three Acts. By' 'I'. W. Robertson. Sixteen Male, five Female Characters. Price...............15 cts.

27. 'B'imbe and 'Hide.-A Drama, in three Acts and a Prologue. By Henry Leslie. Seven Male, fivo Female Characters. Price 15 cts:

28. A roppy Paix-A Comedietta, in one Act. By S. Theyre Smith. One Male, one Female Characters. Price.........15 cts.

29. Tuxning the Tables.A larce, in one Act. By John Poole, Esq. Five Male, three Female Characters. Price....15 cts.

30. The Goose with the Golden Egas.-A Farce, in one Aet. By Messrs. Mayherr and Edwards. Five Male, three Female Characters. Price 15 cts.

31. Taming a 'Tiger. $-A$ Farec, in one Act. Adapted from the French. Three Male Characters. Price...............15 cts.

32. 'Tre Rittle Rebel.- $A$ Farce, in one Act. $13 y$ J. Sterling Coyne. Four Afale, three Female Characters. Price.........15 cts.

\section{One 'oo ntany for IIim.} - A Farce, in ove Act. By T.J. WVilliams, Esq. 'I'wo Male, three Iemale Characters. Price $15 \mathrm{cts}$.

34. Larkin's Love Letters. -A Farce, in one Act, by ' 1 : J. Williams, Esq. 'Three MIale, two Female Characters. Price $15 \mathrm{cts}$.

35. A Silcht Woman.-A Farce, in one Act. By 'Thomas Hailes Lacey. 'I'wo Mrale, one Female Characters. Prico $15 \mathrm{cts}$.

36. Black Sheep.- $-\Lambda$ Drama, in three Acts. By J. Palgrave Simpson and Eimuna Yates. Seven Male, tive Female Characters. Price...............15 cts.

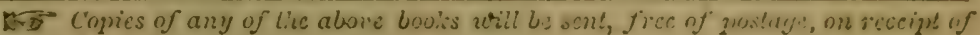
the retail price.

Send Cash Orders to R. M. DE WITT, No. 33 Rose St., N. Y. 


\section{DH WITT'S}

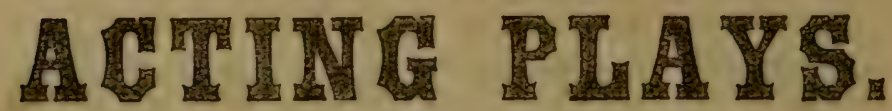

(CONTINUED.)

37. A silent Protector. - A Farce, in one Act. By 'Thomas J. Williams, Esq. Three Male, two Feraale Characters.

Price..................15 cts.

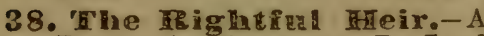
Drama, in five Acts. By Lord Lytton (Sir Edward Lytton Bulwer). 'Ien BIale, two Female Characters. Price..........15 cts.

39. Traster Jones, Birthday.-A Farce, in one Aut. By J. Maddison Morton. Four Male, two Female Characters.

Price................... 15 cts.

10. Atchi.-A Comedietta, in one Act. By J. Maddison Mrorton. Three Male, two Female Characters. Price..............15 ets.

41. Beautiful F'orever, - A Farce, in one Act. By Frederick Hay. 'Two Mrale, two Feruale Characters. Price.........15 cts.

42. 'Tine and the Hour.-A Drama, in three Acts. By J.Palgrave Simpson and Felix Dale. Seven Mrale, three Female Characters. Price..............15 cts.

43. Sisterly Service.-An Original Comedietta, in one Act. By J. P. Wooler., Seven AIale, two Female Characters. Price....15 cts

44. War to the Innife.-A Comedy in three Acts. By Henry J. Byron. Five Mrale, four Female Characters. Price..........15 cts.

45. Our Domestics.-A Comedy Farce, in two Acts. By Frederick Hay. Six Male, six Female Characters. Price...15 cts.

46. Miriam's Crime. - A Drama, in three Acts. By H. T. Craven. Five Male, two Female Characters. Price..........15 cts.

47. Easy Shaving--A Farce, in one Act. By F. C. Burnand and Montague Williams. Five Male, two Female Characters. Price......................15 cts.
48. Hitle Annie's Birthday.-A Farce. By W. E. Suter. Two Male, four Female Characters. Price...............15 cts.

49. 'The Hiduight Watch.A Drama, in one Act. By John J. MIorton. Eight Male, two Female Characters. Price....15 cts.

50. The Porter's 项not.-A Serio-comic Drama, in two Acts. By John Oxenford. Eight Mrale, two Female Characters.

Price.....................15 eta.

51. A Model of at vife, $-A$ Farce, in one Act. By Alfred Wigan, Esq. Three Male, two Female Characters. Price 15 cts.

52. A Cup of 'Tea.-A Come. dietta, in one Act. By Charles Nuitter and J. Derley. Three Arale, one Female Characters.

Price....................15 cts.

53. Gertrude's Money-Risox. - A Farce, in one Ant. By Harxy Lemon. Four Male, two Female Characters. Price.........15 cts.

54. The Young Collegian.$A$ Farce, in one Act. By T. W. Robertson. Three Male, two Female Characters. Price....15 cts.

55. Catherine Howard; or, the 'Throne, the 'Tomb, and the Scafrold. $-A$ Historic Play, in three Acts. By W. D. Suter. Twelve Male, five Female Characters. Price 15 cts.

56. ' $\mathrm{C}$ wo Gay Deceivers; or, Hlack, White and Gray. -A Farce, in one Act. By' $\mathbf{T}$. W. Robertson. Three Male Characters. Price................15 cts.

57. Noemie. - A Drama, in tro Acts. By 'I'. W. Robertson. Four Male, four Female Characters. Price...............15 cts.

58. Deborah (Leah); or, 'Re Jewish Maiden's Wrong.-A Drama, in three Acts. By Charles Smith Cheltnam. Seven Male, Six Female Characters. Price.........15 cts.

Conpies of any of the above Books will be sent, free of postage, on receipt of the retail price.

Send Cash Orders to R. M. DE WITT, No. 33 Rose St., N. Y. 


\section{DE WITT'S \\ HAI愿 DIMTE IVTSTC.}

\section{FOIR TOIEE AND PIANO.}

DE WYTTS MALF DIME MUSIC will contain the most ehoice and exquisite pieces, by the most able, rilted and popular Composers. This selection will comprise every style of really gond music-tiom the solemn and $\mathrm{pa}^{\prime}$ hetic to the light and liumorous. 'The repertoires of the most talentec English and Continental, equally with those of our own native composers, will enrich the series-which will continually range from "grave to gay, from lively to severe."

NOW IEEADY :

1. Pretty Polly, if you Inve me, do 37 . Five O'clock in the MIorning. say Yes.

2. The Fisherman's Daughter that Lives o'er the Water.

3. The Laver's Letter-Bos.

4. I'll Tell Your Wife.

5. 'Ihy Voice is Near.

6. Blue-Eyed Violets.

7. Up in a Balloon.

8. 'The Maiden and Her Linnet.

9. Captain Jinks.

10. Yittle Blue Butterfis.

11. Champagne Charlie.

12. Thady U Flynn.

13. Tassels on the Boots.

14. The Sott Dew is Sleeping.

15. 'Tommy Dodd.

16. When the Roses Blow.

17. 'That's the Style for Me.

18. Pretty Little Flora

19. Bother the Men.

20. Beautitul Bells.

21. The Mother's Dream.

22. I wish I was a Fish; or, Sweet Polly Primrose.

23. MIy Spirit Star.

38. "Good-bre, John;" or, Chickabiddy.

39. She Came and Vanished like a Dream.

40. The Beau of Saratoga.

41. Meet Me in the Lane:

42. Not for Joseph.

43. Tapping at the Garden Gate.

41. Calitornia Gold; or, She was such a Nice Young Girl.

4j. Sleeping on Guard; or, Katic's Love-Letter.

46. It's Better to Laugh than to Cry.

47. The Summer Dew.

48. Susan, Susan, Pity my Confusion.

49. Oh, MIy Lost Iove.

50. Walking in the Park.

51. Far $\Lambda$ way.

52. The Bell Goes, a-ringing for Sairah.

53. Call II

54. On, Boys, on, the Course is always Clear.

55. Jess MacFarlane.

56. The Flying 'Trapeze.

57. Yus, I'll meet 'Thee, Dearest.

58. It's Nice to be a Father.

59. Hativ Bell.

60. Act on the Square, Bors.

61. Whisper, "Yes," or "Xo," Lore.

C2. Her Bright Smile Haunts me Still.

63. (Nh, Cast that sladow from thy Brow.

64. Love Xot.

(i.j. F lie Wore a Treath of Toses.

66. She Danced like a Fairy.

Gi. I Never Go Liast of Madison Equare.

68. The Lanenshire Lass.

33. Immenseikoff.

31. The Way of the World.

35. Ioreaming of Nellie.

36. It's all the Same to Sam.

DE WTTTS IIALF DIME MUSTC can always be obtained at all the News Depots and Music and Book Stores throughont the Lnited States and Canadas. Remember, each No. contains a complete piece of Music, elegantly printed on fine Music puper, and are sold for only

FIVE CEN'S:

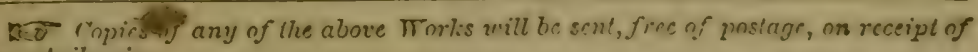
the relail price.

Sand Cash Orlews in J.. M. DE VITT, Jo. sis Roso St., M. Y. 


\section{DE WITT'S}

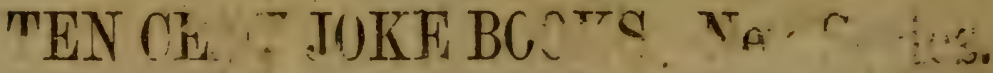

This unrivalled ?ot of Joke Books is crammed full of the tallest kin: of Yanke Stories, Irish 'Tales, Conundrums, Anecdotes, Jests, Jolly Paragrapink, in short, almost every thing funny that has ever been said or written. it tinely sted, in a very neat form. Each book is a perfect epitcme of mirtb.

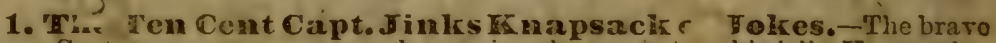
Cajtan never was so popular as since he presente this jo!ly Knapsack.

2. The 'Tena C'ent Shoo Fly Joker.--Joe Miller can't hold a condlo to this liveliest of Joliers. All the clowas in the country get jokes id

3. The Ten Cent Teddy IRegan Jolrer.-The name of this book at once suggests wint a droll affair it is. It is crammed full of the funniest of all jolzes.

Each Joke Book contains One Hundred and Twenty-eight Pages, printed in a very neat form for the Pocket, aud enclosed in a handsome colored cover.

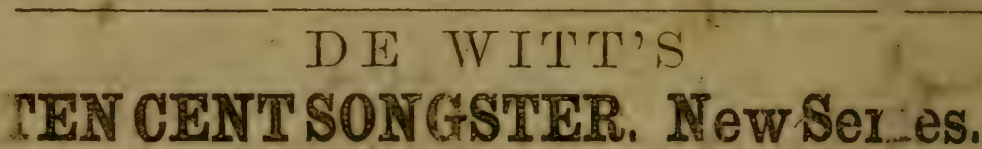

- St This exceclingly pop:lari series contains every song worth singing in the

st suage, trom the most siul to themost merr. A uecessary eomparion for : parlor, the music baliand the:"free ard easy."

1. The Ten Cent silesioche Songster. - Sorne of the most extravagantly funny sungs of the times-such as set all the music halls of London in a frebzy.

2. The Ten Cent rong Branch Songster.-This is the text-book from which all the Blondes of the period draw their most popular songs.

3. 'The' 'Ten Cen Garden Songster. - Ant many sentimental and benutiful songs are interspersed with amusing and cumic ones.

4. The Ten Cent Let Me Hug Her for Her Matirex Songster.-Another of those ininitable song books full of fun and sentiments

5. The "Ten Cent HBig Thing on Ine Songster.-The tak- ing pioture on this boo. woult tempt any one to loois into it.

6. 'Jhe 'Hen Cent Axion Somgster. - The "beautit." blundes" get many of their choic. morsels out of this book It lite a great muny of the best son:-

7. The Ten Cent Schnieder Free and Easy Songsten. -It was found thit neirly es ry person at the Fat Men's Ball ? ad as copy of this book.

8. 'The 'Hen Cent 'Ten citule Injuns Sougster. - The finny song that gives the title to this book is but a faint prelude to tho other rich songs.

9. The Ten Cent WER: \& Sirnning Paix of 1 .ugs Sonigster.-It seems incredible thit such a number of soles can. be sold at such a price.

Thoy are handsomely, rinted in a neat form for the pocket, and es $t \mathrm{k}$ book has one hundred and twenty-eight pages, and enclosed in a handsome colored cover.

Not Copies of any of the above Books will be sent, free of postan- on ? the reio' price.

Send Cash $\cap \cdot$ ciors to R. Mi

т. 




LIBRARY OF CONGRESS

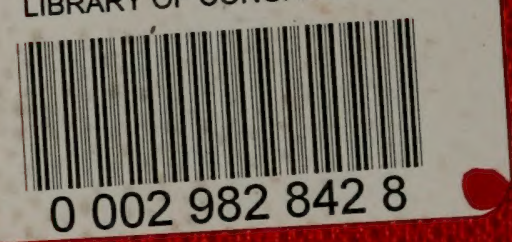

